\title{
Relative importance of gas uptake on aerosol and ground surfaces characterized by equivalent uptake coefficients
}

\author{
Meng $\mathrm{Li}^{1}{ }^{1, a}$, Hang $\mathrm{Su}^{1}$, Guo Li ${ }^{1}$, Nan $\mathrm{Ma}^{2}$, Ulrich Pöschl ${ }^{1}$, and Yafang Cheng ${ }^{1}$ \\ ${ }^{1}$ Max Planck Institute for Chemistry, Mainz, 55118, Germany \\ ${ }^{2}$ Center for Air Pollution and Climate Change Research (APCC), Institute for Environmental and Climate Research (ECI), \\ Jinan University, Guangzhou, 511443, China \\ anow at: Chemical Science Division, Earth System Research Laboratory, National Oceanic and Atmospheric Administration \\ (NOAA), Boulder, Colorado 80305, USA
}

Correspondence: Hang Su (h.su@mpic.de) and Yafang Cheng (yafang.cheng@mpic.de)

Received: 19 March 2019 - Discussion started: 2 April 2019

Revised: 9 July 2019 - Accepted: 19 July 2019 - Published: 29 August 2019

\begin{abstract}
Quantifying the relative importance of gas uptake on the ground and aerosol surfaces helps to determine which processes should be included in atmospheric chemistry models. Gas uptake by aerosols is often characterized by an effective uptake coefficient ( $\left.\gamma_{\text {eff }}\right)$, whereas gas uptake on the ground is usually described by a deposition velocity $\left(V_{\mathrm{d}}\right)$. For efficient comparison, we introduce an equivalent uptake coefficient $\left(\gamma_{\text {eqv }}\right)$ at which the uptake flux of aerosols would equal that on the ground surface. If $\gamma_{\text {eff }}$ is similar to or larger than $\gamma_{\text {eqv }}$, aerosol uptake is important and should be included in atmospheric models. In this study, we compare uptake fluxes in the planetary boundary layer (PBL) for different reactive trace gases $\left(\mathrm{O}_{3}, \mathrm{NO}_{2}, \mathrm{SO}_{2}, \mathrm{~N}_{2} \mathrm{O}_{5}, \mathrm{HNO}_{3}\right.$ and $\mathrm{H}_{2} \mathrm{O}_{2}$ ), aerosol types (mineral dust, soot, organic aerosol and sea salt aerosol), environments (urban areas, agricultural land, the Amazon forest and water bodies), seasons and mixing heights.

For all investigated gases, $\gamma_{\text {eqv }}$ ranges from magnitudes of $10^{-6}-10^{-4}$ in polluted urban environments to $10^{-4}-10^{-1}$ under pristine forest conditions. In urban areas, aerosol uptake is relevant for all species $\left(\gamma_{\text {eff }} \geq \gamma_{\text {eqv }}\right)$ and should be considered in models. On the contrary, contributions of aerosol uptakes in the Amazon forest are minor compared with the dry deposition. The phase state of aerosols could be one of the crucial factors influencing the uptake rates. Current models tend to underestimate the $\mathrm{O}_{3}$ uptake on liquid organic aerosols which can be important, especially over regions with $\gamma_{\text {eff }} \geq \gamma_{\text {eqv }} \cdot \mathrm{H}_{2} \mathrm{O}_{2}$ uptakes on a variety of aerosols are yet to be measured under laboratory conditions and evaluated.
\end{abstract}

Given the fact that most models have considered the uptakes of these species on the ground surface, we suggest also considering the following processes in atmospheric models: $\mathrm{N}_{2} \mathrm{O}_{5}$ uptake by all types of aerosols, $\mathrm{HNO}_{3}$ and $\mathrm{SO}_{2}$ uptake by mineral dust and sea salt aerosols, $\mathrm{H}_{2} \mathrm{O}_{2}$ uptake by mineral dust, $\mathrm{NO}_{2}$ uptakes by sea salt aerosols and $\mathrm{O}_{3}$ uptake by liquid organic aerosols.

\section{Introduction}

Multiphase processes play an essential role in atmospheric chemistry and atmosphere-biosphere exchange (Ravishankara, 1997; Ammann et al., 1998, 2013; Gard et al., 1998; Usher et al., 2003; Bauer et al., 2004; Fowler et al., 2009; Kolb et al., 2010; Su et al., 2011, 2013; Herrmann, 2003; Herrmann et al., 2015; Pöhlker et al., 2012; Oswald et al., 2013; Andreae et al., 2015; George et al., 2015; McNeill, 2015; Pöschl and Shiraiwa, 2015; Quinn et al., 2015; Weber et al., 2015; Cheng et al., 2016; Fröhlich-Nowoisky et al., 2016; Lappalainen et al., 2016; Tang et al., 2016; Meusel et al., 2018). They not only affect the atmospheric trace gas concentrations but also modify the properties of condensed phases, commonly known as the aging process (Song and Carmichael, 1999; Cheng et al., 2006, 2012; Rudich et al., 2007; Andreae 2009; Jimenez et al., 2009; Gunthe et al., 2011; Ditas et al., 2018). In the planetary boundary layer (PBL), aerosols and the ground provide two kinds of surfaces for multiphase reactions. In previous gas uptake stud- 
ies, different formulations have been used to describe and parameterize the gas uptake processes (Wesely, 1989, 2007; Ravishankara, 1997; Jacob, 2000; Wesely and Hicks, 2000; Zhang et al., 2003; Ammann and Pöschl, 2007; Pöschl et al., 2007).

A variety of ground surfaces, including vegetation, water, rock, roads and so on, can take up gaseous species via dry deposition, and, thus, have significant impacts on the budget of these reactive gases and on the physicochemical properties of the ground surface itself (Lelieveld and Dentener, 2000; Ashmore, 2005). Dry deposition is one of the major removal pathways for most gaseous species and has been extensively parameterized in atmospheric models (Wesely and Hicks, 2000; Zhang et al., 2002, 2003). A resistance model, which consists of the aerodynamic resistance, quasi-laminar resistance and surface resistance, has been widely applied to calculate the dry deposition flux in global and regional atmospheric models (see Fig. 1, Wesely and Hicks, 2000; Wesely, 2007). The dry deposition velocity, $V_{\mathrm{d}}$ (in units of $\mathrm{cm} \mathrm{s}^{-1}$ ) calculated as the reciprocal of the total resistance, is the key parameter to describe the uptake fluxes on the ground.

Since the late 1990 s, the importance of reactive uptake of gases by aerosols has been commonly accepted (Ravishankara, 1997; Gard et al., 1998; Jacob, 2000). Gas uptake by aerosols not only influences the fate of reactive gases, but also changes the physiochemical properties of atmospheric aerosols (Kolb et al., 2010). Taking the multiphase chemistry into account has proven to be a key factor to explain the observations and improve the model performances (Zhang and Carmichael, 1999; Song and Carmichael, 2001; Liao and Seinfeld, 2005; Wang et al., 2006; McNaughton et al., 2009; X. Wang, et al., 2012; B. Zheng et al., 2015; Tang et al., 2017; Chen et al., 2018; Mu et al., 2018). Compared with dry deposition, the parameterization of gas uptake on aerosols is more challenging (Jacob, 2000; Pöschl and Shiraiwa, 2015). The mass transfer between gases and aerosols can be described by the resistance model in analogy with an electrical circuit that decoupled the physiochemical limitations in the gas phase, gas-surface interface and the bulk phase under (quasi-) steady-state conditions (Schwartz and Freiberg, 1981; Schwartz, 1986; Kolb et al., 1995). A simplified scheme, which relies on the formulation of an effective uptake coefficient $\left(\gamma_{\text {eff }}\right)$ has been widely used in current atmospheric models (Jacob, 2000; Liao and Seinfeld, 2005; K. Wang et al., 2012). Growing numbers of laboratory studies have reported $\gamma_{\text {eff }}$ for various trace gases and aerosol particles that are potentially important for atmospheric chemistry, such as $\mathrm{O}_{3}, \mathrm{NO}_{2}, \mathrm{SO}_{2}, \mathrm{~N}_{2} \mathrm{O}_{5}, \mathrm{HNO}_{3}$ on mineral dust (Ullerstam et al., 2002; Mogili et al., 2006; Vlasenko et al., 2006; Wagner et al., 2008; Ndour et al., 2009), soot (Rogaski et al., 1997; Longfellow et al., 2000; Al-Abadleh and Grassian, 2000; Saathoff et al., 2001) and sea salt aerosols (Mochida et al., 2000; Gebel and FinlaysonPitts, 2000; Hoffman et al., 2003; Thornton and Abbatt, 2005; Ye et al., 2010). A series of evaluations on the kinetic and photochemical data for the multiphase reactions were conducted afterwards (Crowley et al., 2010, 2013; Ammann et al., 2013; Burkholder et al., 2015). Pöschl et al. (2007), and the follow-up studies (e.g., Shiraiwa et al., 2010, 2011) developed a comprehensive kinetic model framework, enabling consistent and unambiguous descriptions of mass transfer and chemical reactions in aerosol systems.

However, the question still remains as to which surface types are more important for gas uptake in the PBL. The answer is not straightforward due to the following reasons:

1. First, although the surface of the Earth seems to be much larger than that of tiny aerosols, its contribution is diluted by the large volume of the PBL, resulting in a surface to volume ratio close to that of aerosol; for example, for a PBL height of $1000 \mathrm{~m}$, the corresponding surface to volume ratio is $1000 \mu \mathrm{m}^{2} \mathrm{~cm}^{-3}$, which is comparable to aerosol surface area concentrations of 200-2000 $\mathrm{\mu m}^{2} \mathrm{~cm}^{-3}$ for urban areas (Woo et al., 2001; Stanier et al., 2004; Wu et al., 2008, 2017; Ma and Birmili, 2015) and $200-1000 \mu^{2} \mathrm{~cm}^{-3}$ for rural environments (Ma et al., 2014; Ma and Birmili, 2015; Wu et al., 2017; Held et al., 2008).

2. Second, different formulations also hinder the comparison. As illustrated above, different schemes, formulations and terminologies are applied to calculate the uptake fluxes on ground and aerosols. The dry deposition velocity $\left(V_{\mathrm{d}}\right)$ is the fundamental parameter to describe the deposition process on the ground, whereas the effective uptake coefficient $\left(\gamma_{\text {eff }}\right)$ is used to describe the uptake fluxes on aerosols.

In this study, we conducted a comparative assessment of the gas uptake on both ground and aerosol surfaces. Our goal is to identify the prevailing multiphase process in the PBL, especially those processes that have not yet been sufficiently considered in atmospheric models. Section 2 describes the methods of calculation and comparison. We present and discuss the main results in Sect. 3, which is followed by a summary of our major findings in Sect. 4.

\section{Methods}

In this work, we compared the relative importance of gas uptake by the ground and by aerosols based on their uptake fluxes. In this comparison, resistance models were applied to calculate uptake fluxes on both ground and aerosol surfaces (see Fig. 1) as detailed below. The uptake fluxes of six reactive gases $\left(\mathrm{O}_{3}, \mathrm{NO}_{2}, \mathrm{SO}_{2}, \mathrm{~N}_{2} \mathrm{O}_{5}, \mathrm{HNO}_{3}\right.$ and $\left.\mathrm{H}_{2} \mathrm{O}_{2}\right)$ were calculated and compared for four typical land use categories (urban areas, agricultural land, the Amazon forest and water) and five aerosol types (mineral dust, soot, solid organic aerosol, liquid organic aerosol and sea salt aerosol). These species were chosen considering their potential impor- 


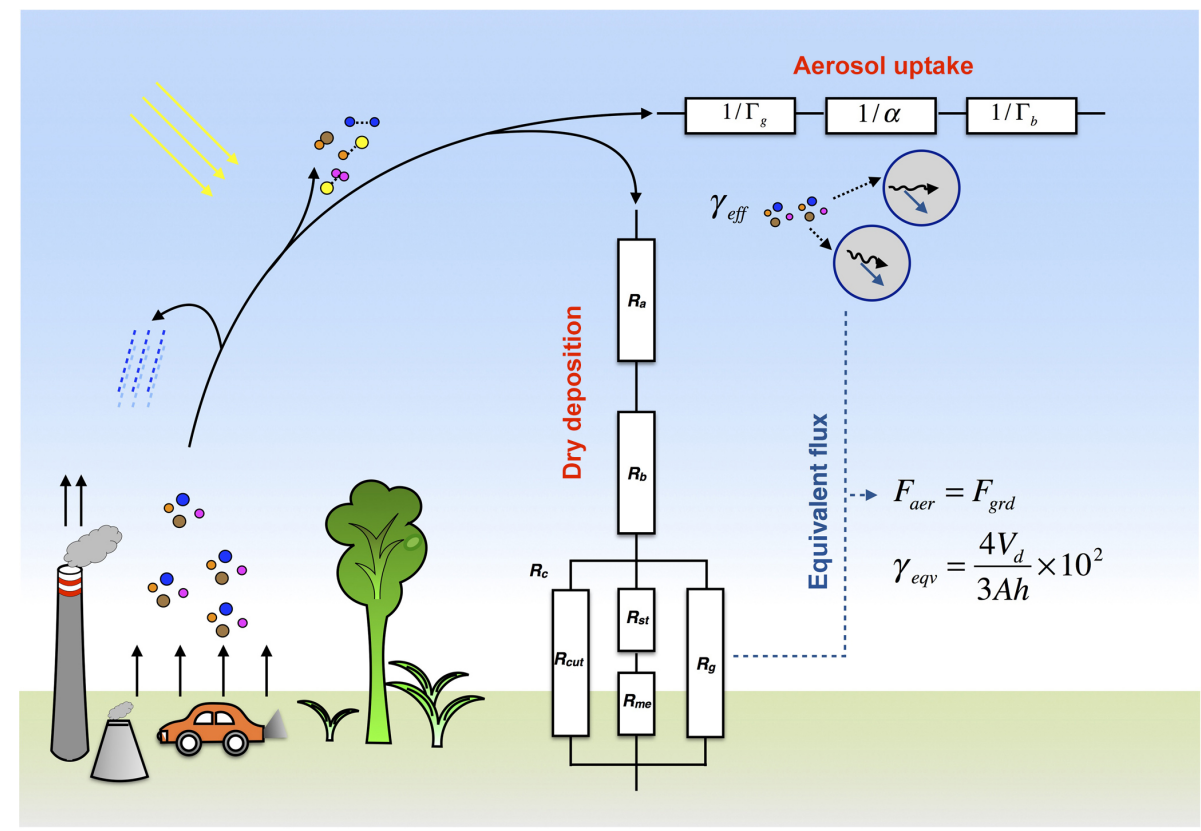

Figure 1. Schematic illustration of gas uptake on the ground and on aerosols in the planetary boundary layer as characterized by resistance models. The relative importance of aerosol uptake and dry deposition on the ground is characterized by comparing the aerosol uptake coefficient $\left(\gamma_{\text {eff }}\right)$ with an equivalent uptake coefficient $\left(\gamma_{\text {eqv }}\right)$ corresponding to the deposition velocity $\left(V_{\mathrm{d}}\right)$.

tance regarding dry deposition on the ground and uptake on aerosols within the troposphere.

\subsection{Ground gas uptake}

Dry deposition fluxes were calculated following the scheme and parameters of Wesely (1989) and Zhang et al. (2003). As shown in Fig. 1, the resistance model applied to characterize the dry deposition process includes the aerodynamic resistance $\left(R_{\mathrm{a}}\right)$, quasi-laminar resistance $\left(R_{\mathrm{b}}\right)$ and surface resistance $\left(R_{\mathrm{c}}\right)$. The basic equations for the flux calculations are as follows:

$F_{\text {grd }}=-V_{\mathrm{d}}\left[X_{\mathrm{g}}\right] \times 10^{-2}$

$V_{\mathrm{d}}=\frac{1}{R_{\mathrm{grd}}}=\frac{1}{R_{\mathrm{a}}+R_{\mathrm{b}}+R_{\mathrm{c}}}$

where $F_{\text {grd }}$ represents the gas deposition fluxes on various ground surfaces $\left(\mathrm{mol} \mathrm{m}^{-2} \mathrm{~s}^{-1}\right) ; V_{\mathrm{d}}$ represents the deposition velocity $\left(\mathrm{cm} \mathrm{s}^{-1}\right) ;\left[X_{\mathrm{g}}\right]$ is the averaged gas concentration ( $\mathrm{mol} \mathrm{m}^{-3}$ ); and $R_{\text {grd }}$ is the total resistance in the dry deposition process ( $\mathrm{s} \mathrm{cm}^{-1}$ ), composed of $R_{\mathrm{a}}, R_{\mathrm{b}}$ and $R_{\mathrm{c}}$. The detailed equations and parameterization scheme for the determination of $R_{\mathrm{a}}, R_{\mathrm{b}}$ and $R_{\mathrm{c}}$ are provided in the Supplement. A neutral meteorological condition was assumed in the calculation. We present the key input parameters and the calculated $V_{\mathrm{d}}$ in Tables $\mathrm{S} 1$ and $\mathrm{S} 2$, respectively.

\subsection{Aerosol gas uptake and the effective uptake coefficient $\left(\gamma_{\text {eff }}\right)$}

The net flux of gas $X$ from the gas phase to the condensed phase $\left(J_{\text {net }}, \mathrm{mol} \mathrm{m}^{-2} \mathrm{~s}^{-1}\right)$ for one aerosol particle can be expressed as Eq. (3) under (quasi-) steady-state conditions (Pöschl et al., 2007):

$J_{\text {net }}=\frac{\omega \gamma_{\text {eff }}}{4}\left[X_{\mathrm{g}}\right]$

The effective uptake coefficient, $\gamma_{\text {eff }}$, represents the number of gas molecules taken by the aerosol particle divided by the number of those impacting onto the particle surface (Pöschl et al., 2007); $\omega$ is the mean thermal velocity $\left(\mathrm{m} \mathrm{s}^{-1}\right)-$ we use a typical value of $300 \mathrm{~m} \mathrm{~s}^{-1}$ in this study; $\left[X_{\mathrm{g}}\right]$ is the averaged gas concentration far away from the aerosol surface $\left(\mathrm{mol} \mathrm{m}^{-3}\right)$.

$\frac{1}{\gamma_{\text {eff }}}=\frac{1}{\Gamma_{\mathrm{g}}}+\frac{1}{\alpha}+\frac{1}{\Gamma_{\mathrm{b}}}$

As shown in Fig. 1, resistance models have been widely applied to quantify the mass transfer of gases to aerosol particles. For gas uptake on liquid droplets, following the resistance model as described by Eq. (4), the overall resistance $1 / \gamma_{\text {eff }}$ is composed of three resistor terms due to gas diffusion $\left(1 / \Gamma_{\mathrm{g}}\right)$, interfacial mass transfer $(1 / \alpha)$ and bulk diffusion and reaction $\left(1 / \Gamma_{\mathrm{b}}\right)$ (Pöschl et al., 2007). The conductance of gas diffusion is commonly calculated based on $\Gamma_{\mathrm{g}}=8 D_{\mathrm{g}} \omega^{-1} d_{\mathrm{p}}^{-1}$, where $D_{\mathrm{g}}$ is the diffusion coefficient of 
Table 1. Aerosol uptake coefficients $\left(\gamma_{\text {eff }}\right)$ observed in laboratory experiments ${ }^{a}$.

\begin{tabular}{|c|c|c|c|c|c|}
\hline Gases & Mineral dust & Soot & Solid organic aerosol & Liquid organic aerosol & Sea salt aerosol \\
\hline \multicolumn{6}{|c|}{ Steady state ${ }^{b}$} \\
\hline $\mathrm{O}_{3}$ & $4.4 \times 10^{-9}-4.8 \times 10^{-5}$ & $1.0 \times 10^{-7}-1.6 \times 10^{-4}$ & $2.0 \times 10^{-6}-6.9 \times 10^{-5}$ & $1.1 \times 10^{-5}-3.0 \times 10^{-3}$ & $1.3 \times 10^{-6}-1.0 \times 10^{-4}$ \\
\hline $\mathrm{NO}_{2}$ & $1.0 \times 10^{-9}-2.3 \times 10^{-7}$ & $<5.0 \times 10^{-8}$ & $<5.0 \times 10^{-7}$ & $2.2 \times 10^{-7}-7.0 \times 10^{-6}$ & $6.0 \times 10^{-7}-3.0 \times 10^{-4}$ \\
\hline $\mathrm{SO}_{2}$ & $1.5 \times 10^{-8}-6.3 \times 10^{-4}$ & $4.0 \times 10^{-9}-2.2 \times 10^{-6}$ & $\mathrm{n} / \mathrm{a}$ & $\mathrm{n} / \mathrm{a}$ & $3.2 \times 10^{-3}-1.7 \times 10^{-2}$ \\
\hline $\mathrm{N}_{2} \mathrm{O}_{5}$ & $4.8 \times 10^{-3}-2.0 \times 10^{-1}$ & $4.0 \times 10^{-5}-6.3 \times 10^{-3}$ & $1.0 \times 10^{-5}-3.1 \times 10^{-3}$ & $5.0 \times 10^{-5}-4.5 \times 10^{-2}$ & $6.4 \times 10^{-3}-3.9 \times 10^{-2}$ \\
\hline $\mathrm{HNO}_{3}$ & $1.0 \times 10^{-3}-2.1 \times 10^{-1}$ & $3.0 \times 10^{-7}-1.5 \times 10^{-3}$ & $\mathrm{n} / \mathrm{a}$ & $\mathrm{n} / \mathrm{a}$ & $5.0 \times 10^{-4}-2.5 \times 10^{-1}$ \\
\hline $\mathrm{H}_{2} \mathrm{O}_{2}$ & $1.0 \times 10^{-5}-9.4 \times 10^{-4}$ & $\mathrm{n} / \mathrm{a}^{\mathrm{c}}$ & $\mathrm{n} / \mathrm{a}$ & $\mathrm{n} / \mathrm{a}$ & $\mathrm{n} / \mathrm{a}$ \\
\hline \multicolumn{6}{|c|}{ Initial state ${ }^{b}$} \\
\hline $\mathrm{O}_{3}$ & $2.0 \times 10^{-7}-3.5 \times 10^{-4}$ & $1.4 \times 10^{-4}-1.0 \times 10^{-3}$ & $1.0 \times 10^{-5}$ & $5.5 \times 10^{-4}-1.6 \times 10^{-3}$ & $1.0 \times 10^{-3}-3.6 \times 10^{-2}$ \\
\hline $\mathrm{NO}_{2}$ & $2.5 \times 10^{-9}-2.2 \times 10^{-5}$ & $1.0 \times 10^{-6}-4.0 \times 10^{-4}$ & $1.0 \times 10^{-7}-5.1 \times 10^{-6}$ & $2.0 \times 10^{-5}$ & $1.0 \times 10^{-4}$ \\
\hline $\mathrm{SO}_{2}$ & $1.4 \times 10^{-7}-7.7 \times 10^{-4}$ & $3.0 \times 10^{-3}$ & $\mathrm{n} / \mathrm{a}$ & $9.2 \times 10^{-7}-1.0 \times 10^{-5}$ & $6.9 \times 10^{-3}-9.0 \times 10^{-2}$ \\
\hline $\mathrm{N}_{2} \mathrm{O}_{5}$ & $2.0 \times 10^{-2}-3.0 \times 10^{-1}$ & $1.6 \times 10^{-2}-4.4 \times 10^{-2}$ & $\mathrm{n} / \mathrm{a}$ & $\mathrm{n} / \mathrm{a}$ & $\mathrm{n} / \mathrm{a}$ \\
\hline $\mathrm{HNO}_{3}$ & $2.5 \times 10^{-4}-1.8 \times 10^{-1}$ & $7.7 \times 10^{-4}-2.0 \times 10^{-2}$ & $\leq 6.6 \times 10^{-5}$ & $\mathrm{n} / \mathrm{a}$ & $6.6 \times 10^{-2}-7.5 \times 10^{-1}$ \\
\hline $\mathrm{H}_{2} \mathrm{O}_{2}$ & $5.0 \times 10^{-5}-4.0 \times 10^{-3}$ & $\mathrm{n} / \mathrm{a}$ & $\mathrm{n} / \mathrm{a}$ & $\mathrm{n} / \mathrm{a}$ & $\mathrm{n} / \mathrm{a}$ \\
\hline
\end{tabular}

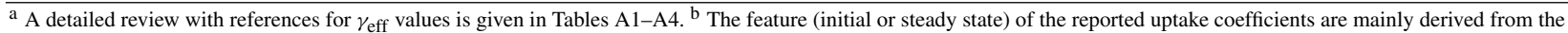
literature. If no specific description is found, we assign the measurements on a timescale of milliseconds or seconds to the initial state, and those with a longer exposure time $(\sim 1 \mathrm{~h}$ or longer) to the steady state. " "n/a" denotes not available.

gas $X$ in the gas phase $\left(\mathrm{m}^{2} \mathrm{~s}^{-1}\right)$, and $d_{\mathrm{p}}$ represents the aerosol particle diameter. For large particles and very fast uptake processes, the gas diffusion process can be a limiting factor for the overall uptake (Tang et al., 2014a). For atmospheric aerosols with a diameter of $\sim 0.2 \mu \mathrm{m}$, the related gaseous uptake tends to be limited by the free molecular collision rate (uptake rate $\rightarrow \omega \alpha A\left[X_{\mathrm{g}}\right] / 4$ ) (Jacob, 2000). Thus, in the following analyses, we mainly focus on the discussion of $\gamma_{\mathrm{eff}}$, and neglect the diffusion resistance in the gas phase.

Given a mixing height of $h$ and an aerosol surface area density of $A$ (particle surface area per unit volume of air, $\left.\mu \mathrm{m}^{2} \mathrm{~cm}^{-3}\right)$, the total uptake flux of gas $X$ by aerosols $\left(F_{\text {aer }}\right.$, $\left.\mathrm{mol} \mathrm{m} \mathrm{m}^{-2} \mathrm{~s}^{-1}\right)$ is

$F_{\text {aer }}=J_{\text {net }} A h=\frac{\omega \gamma_{\text {eff }}}{4} A h\left[X_{\mathrm{g}}\right] \times 10^{-6}$,

where $10^{-6}$ is the unit conversion factor. We summarized the measured uptake coefficients for a variety of gas species and aerosol types at both the initial state and the steady state in Table 1 (details in Tables A1-A4). These coefficients are mainly derived from measured values in the literature, reviewed data from the IUPAC (International Union of Pure and Applied Chemistry) "Task Group on Atmospheric Chemical Kinetic Data Evaluation" (Crowley et al., 2010, 2013; Ammann et al., 2013; available at http://iupac. pole-ether.fr/, last access: January 2019) and the NASA JPL (Jet Propulsion Laboratory, Burkholder et al., 2015) (see references in Tables A1-A4). As we focus on the PBL, $\gamma_{\text {eff }}$ values measured at room temperatures $(\sim 298 \mathrm{~K})$ are mainly presented. Gas uptakes at very low temperatures (e.g., in the polar region or stratosphere) are outside the scope of this study and should be explored in future work.
Although the initial and steady-state uptake coefficients are listed, it should be noted that the values at the initial state may not be appropriate for direct application in chemical transport models (CTMs) considering the subsequent surface saturation and depletion of reactants for several cases (e.g., on mineral dust and soot; Ndour et al., 2009; Stephens et al., 1986; Ammann et al., 1998; Kalberer et al., 1999). In general, the upper limit and lower limit are determined based on those derived using the geometric surface and the BET (Brunauer-Emmett-Teller) surface, respectively. Preferences are given to those measured at steady state using ambient aerosols, or values recommended by the IUPAC group with relatively high reliability. As shown in Table A1, variances of more than 3 orders of magnitude are found for $\mathrm{SO}_{2}$ and $\mathrm{O}_{3}$ uptake on mineral dust depending on the gas concentration and aerosol components (Michel et al., 2002, 2003; Mogili et al., 2006; Ullerstam et al., 2002, 2003; Li et al., 2006). Large discrepancies also exist for $\mathrm{SO}_{2}$ and $\mathrm{HNO}_{3}$ uptake on soot (Longfellow et al., 2000; Saathoff et al., 2001; $\mathrm{Xu}$ et al., 2015). For $\mathrm{H}_{2} \mathrm{O}_{2}$, limited measurements of $\gamma_{\text {eff }}$ have been conducted for aerosols apart from mineral dust.

\subsection{Uptake coefficient at equivalent flux ( $\left.\gamma_{\text {eqv }}\right)$}

To help the evaluation, we define an uptake coefficient at equivalent flux $\gamma_{\text {eqv }}$. Here, $\gamma_{\text {eqv }}$ is the effective uptake coefficient on aerosols when the ground flux equals the aerosol flux within the PBL. When $\gamma_{\text {eff }}>\gamma_{\text {eqv }}$, the aerosol surfaces are more important than the ground surfaces regarding the gas uptake and vice versa. By letting $F_{\text {grd }}$ equal $F_{\text {aer }}$, we can derive the expression for $\gamma_{\text {eqv }}$ as follows:

$\gamma_{\mathrm{eqv}}=\frac{4}{3} \frac{V_{\mathrm{d}}}{A h} \times 10^{2}$ 


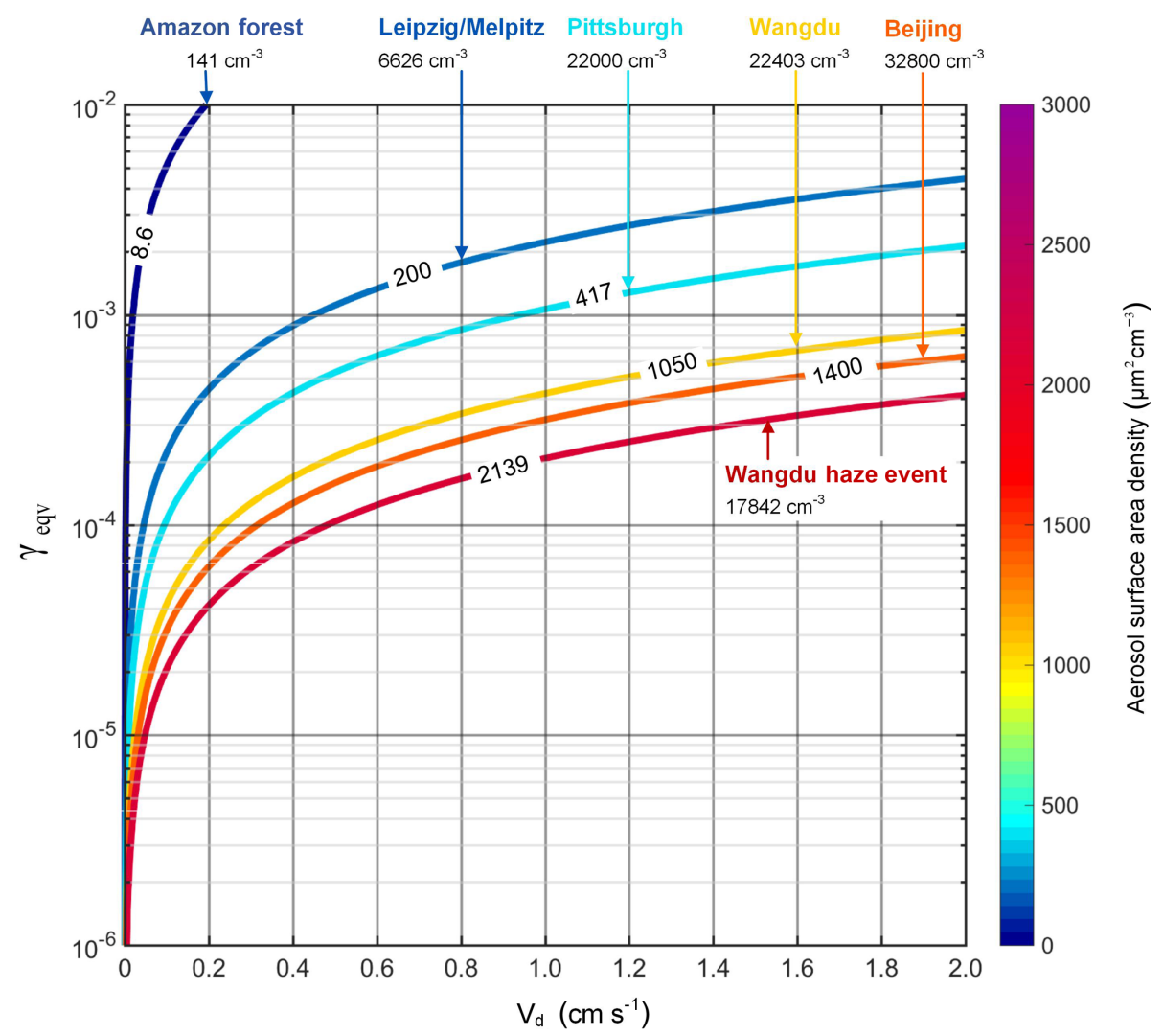

Figure 2. Relation between $\gamma_{\mathrm{eqv}}$ and $V_{\mathrm{d}}$ for a mixing height of $300 \mathrm{~m}$ and aerosol surface area densities $(A)$ observed at different locations and under different conditions: Amazon forest (Pöschl et al., 2010), Leipzig/Melpitz (Ma et al., 2014; Ma and Birmili, 2015), Pittsburgh (Stanier et al., 2004), Wangdu with and without haze event (Wu et al., 2017) and Beijing (Wu et al., 2008). For each city/condition, the line is labeled with the corresponding aerosol surface area density. Aerosol particle number concentrations are also provided for orientation.

and at a typical mixing height of $300 \mathrm{~m}$, we have

$\gamma_{\mathrm{eqv}}=\frac{V_{\mathrm{d}}}{2.25 A}$

According to Eq. (6), $\gamma_{\text {eqv }}$ is proportional to $V_{\mathrm{d}}$, and is inversely proportional to the aerosol surface area density and the mixing height. We calculated a series of $\gamma_{\text {eqv }}$ values for a variety of gas species, land use categories, seasons, aerosol surface area densities $(A)$ and mixing heights $(h)$.

As defined, $\gamma_{\text {eqv }}$ reflects the relative importance of gas uptake on aerosols compared to those on the ground surfaces. Larger $\gamma_{\text {eqv }}$ indicates a higher probability for gases to deposit on the ground rather than on aerosols for further chemical reactions on surface and bulk, and vice versa. Low dry deposition velocities and high loadings of aerosols providing large amounts of surface reaction sites can benefit gas uptake on aerosols. The derived $\gamma_{\text {eqv }}$ and $\gamma_{\text {eff }}$ values from laboratory measurements are compared in Sect. 3.

\section{Results and discussion}

To estimate the possible range of $\gamma_{\text {eqv }}$ for different environments, we designed different scenarios with the mixing height $h$ varying between $100 \mathrm{~m}$ and $1.0 \mathrm{~km}$ (a typical value of $300 \mathrm{~m}$ ), and $A$ varying with land use categories as follows:

a. Range of $A$ : we set the range of $A$ based on measurements in various environments collected from the literature. $A$ values are in the range of $200-2000 \mu \mathrm{m}^{2} \mathrm{~cm}^{-3}$ for aerosols in urban areas (Woo et al., 2001; Stanier et al., 2004; Wu et al., 2008, 2017; Ma and Birmili, 2015), $200-1000 \mu \mathrm{m}^{2} \mathrm{~cm}^{-3}$ in agricultural regions (suburban and rural, Held et al., 2008; Su et al., 2008b; Ma et al., 2014; Ma and Birmili, 2015; Wu et al., 2017), 8 $700 \mu \mathrm{m}^{2} \mathrm{~cm}^{-3}$ in the Amazon forest (Zhou et al., 2002; Rissler et al., 2006; Pöschl et al., 2010; Andreae et al., 2015) and 20-200 $\mu^{2} \mathrm{~cm}^{-3}$ for sea salt aerosols (SSA, O'Dowd et al., 1997; Ghan et al., 1998; Lewis and Schwartz, 2004).

b. Typical $A$ (corresponding to the typical $\gamma_{\text {eqv }}$ in Figs. 3 5): we use $1050 \mu \mathrm{m}^{2} \mathrm{~cm}^{-3}$ for the urban environment (Wu et al., 2017), $230 \mu \mathrm{m}^{2} \mathrm{~cm}^{-3}$ for agricultural regions (Held et al., 2008), $46 \mu \mathrm{m}^{2} \mathrm{~cm}^{-3}$ for the Amazon forest (Rissler et al., 2006) and $76 \mu \mathrm{m}^{2} \mathrm{~cm}^{-3}$ for SSA (canonical distribution at a wind speed of $10 \mathrm{~m} \mathrm{~s}^{-1}$, Lewis and Schwartz, 2004). 
It should be noted that the above ranges and the typical values of $A$ are derived from current available experiments to support our analyses and discussions in this study, but still cannot cover all cases of particle distributions in the world.

Figure 2 shows the calculated $\gamma_{\text {eqv }}$ over a range of dry deposition velocities and aerosol surface area densities at a mixing height of $300 \mathrm{~m}$. $V_{\mathrm{d}}$ values for different scenarios were calculated based on the resistance scheme illustrated above, showing a range of $0.01-2.3 \mathrm{~cm} \mathrm{~s}^{-1}$, with the lowest for $\mathrm{NO}_{2}$ and the highest for $\mathrm{N}_{2} \mathrm{O}_{5}$ and $\mathrm{HNO}_{3}$ (details in Table S2). Aerosol surface area densities covered a range of 8.6 to $2139 \mu \mathrm{m}^{2} \mathrm{~cm}^{-3}$, from pristine rainforest to polluted megacities, respectively. We show the calculated $\gamma_{\text {eqv }}$ under typical conditions (typical $A$ as described above, $h=300 \mathrm{~m}$ ) by season in Table $\mathrm{S} 3$ and a detailed illustrated $\gamma_{\text {eqv }}$ for each gas species in the sections below. As shown in Fig. 2, $\gamma_{\text {eqv }}$ decreases with increasing $A$, which is closely related to the air pollution level, and increases with increasing $V_{\mathrm{d}}$.

For small $V_{\mathrm{d}}\left(\leq 0.1 \mathrm{~cm} \mathrm{~s}^{-1}\right), \gamma_{\text {eqv }}$ values lie in the range of $10^{-5}-10^{-4}$ for clean regions, such as Leipzig, Melpitz and Pittsburgh, and decrease to $10^{-6}-10^{-5}$ in polluted cities including Beijing and Wangdu. This low dry deposition can be found for $\mathrm{NO}_{2}$ above the urban ground $\left(0.03 \mathrm{~cm} \mathrm{~s}^{-1}\right.$, seasonal mean), and $\mathrm{O}_{3}, \mathrm{NO}_{2}, \mathrm{SO}_{2}$ and $\mathrm{H}_{2} \mathrm{O}_{2}$ on water bodies (0.07, 0.01, 0.03 and $0.08 \mathrm{~cm} \mathrm{~s}^{-1}$, respectively). The downward shift of $\gamma_{\text {eqv }}$ with larger aerosol surface area density suggests the increased importance of gas uptake in polluted areas compared with clean areas.

With the increase of $V_{\mathrm{d}}\left(>0.1 \mathrm{~cm} \mathrm{~s}^{-1}\right), \gamma_{\text {eqv }}$ increases to $10^{-5}-10^{-2}$ accordingly. In a pristine region of the Amazon forest, $\gamma_{\text {eqv }}$ can reach up to $10^{-2}$. The lowest $\gamma_{\text {eqv }}$ is $2.1 \times 10^{-5}$ during haze events with high concentrations of fine particulate matter and surface area in the PBL $(A=$ $2139 \mu \mathrm{m}^{2} \mathrm{~cm}^{-3}$ ). In this study, this range of $V_{\mathrm{d}}$ covers most of the investigated cases, including $\mathrm{O}_{3}, \mathrm{SO}_{2}, \mathrm{H}_{2} \mathrm{O}_{2}$ on urban/Amazon forest/agricultural region, $\mathrm{NO}_{2}$ on agricultural region/Amazon forest, and $\mathrm{N}_{2} \mathrm{O}_{5}$ and $\mathrm{HNO}_{3}$ over all land use types (see Table S2). Thus, we can derive a general conservative criterion of $\gamma_{\mathrm{eff}}>10^{-5}$ for aerosol uptake to compete with the dry deposition.

In the following, we further compared $\gamma_{\text {eqv }}$ to the laboratory measurements of $\gamma_{\text {eff }}$ for different reactive gases $\left(\mathrm{O}_{3}\right.$, $\mathrm{NO}_{2}, \mathrm{SO}_{2}, \mathrm{~N}_{2} \mathrm{O}_{5}, \mathrm{HNO}_{3}$ and $\left.\mathrm{H}_{2} \mathrm{O}_{2}\right)$. The uptake coefficients at the initial state are generally 1-3 magnitudes higher than those at steady state (see Table 1 and Figs. 3-5). Considering the timescale of gas uptake by aerosols in the real world and applications in models, we mainly focus on the comparisons of $\gamma_{\text {eqv }}$ and the steady-state $\gamma_{\text {eff }}$ in the following discussions.

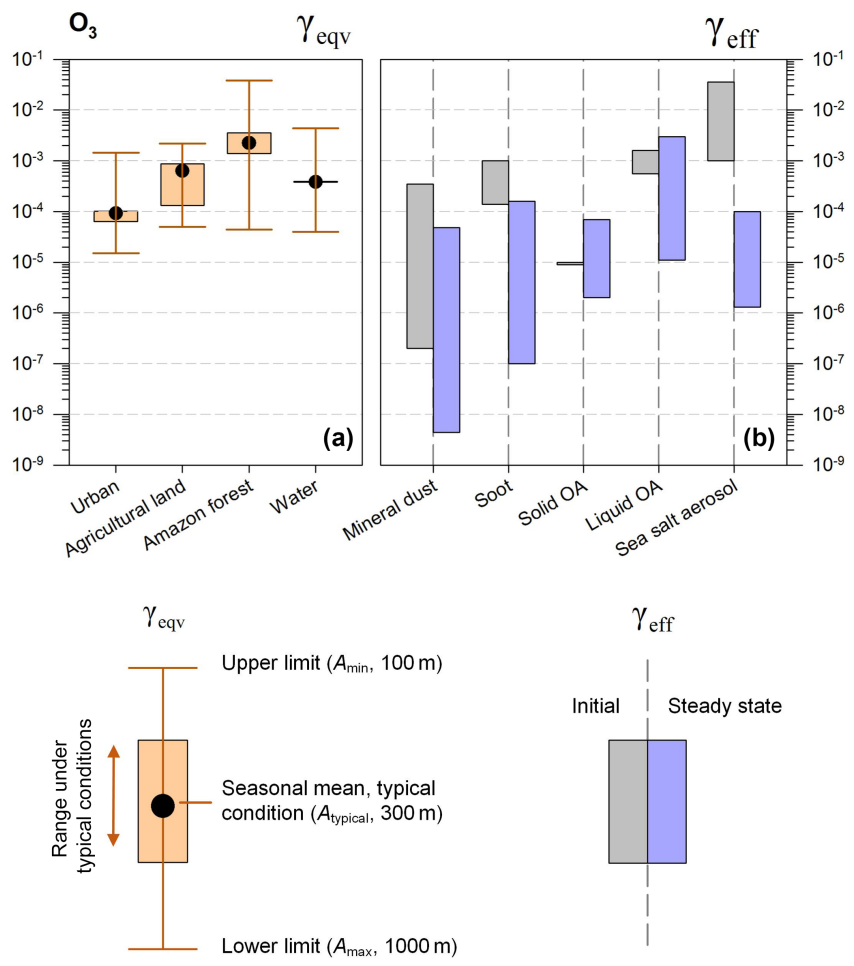

Figure 3. Equivalent uptake coefficients $\left(\gamma_{\mathrm{eqv}}, \mathbf{a}\right)$ and laboratory measurement values $\left(\gamma_{\text {eff }}, \mathbf{b}\right)$ for $\mathrm{O}_{3}$ on different ground types and aerosols. For $\gamma_{\text {eqv }}$, the upper whiskers represent maximum values calculated at the lowest $A$ and $h(h=100 \mathrm{~m})$, the lower whiskers represent minimum values calculated at the highest $A$ and $h(h=1 \mathrm{~km})$, and boxes represent typical conditions (typical $A$ as described in Sect. 3.1, $h=300 \mathrm{~m}$ ). For $\gamma_{\text {eff }}$, the gray bar represents the range of initial values, and the blue bar represents the range of steady-state values observed in laboratory experiments.

\section{$3.1 \quad \mathrm{O}_{3}$}

Under typical conditions (typical $A$ by land use, $h=300 \mathrm{~m}$, as illustrated above), $\gamma_{\text {eqv }}$ values for $\mathrm{O}_{3}$ between $9.2 \times 10^{-5}$ and $2.2 \times 10^{-3}$ are determined, with the lowest value in urban areas and the highest value in the Amazon forest. The extended range is $1.4 \times 10^{-5}-3.8 \times 10^{-2}$, which varies with particle area densities and mixing heights (Fig. 3). There are overlaps between $\gamma_{\text {eqv }}$ and $\gamma_{\text {eff }}$ for liquid organic aerosols (OAs) among all investigated typical environments, and other types of aerosols under favorable circumstances for aerosol uptake in urban areas. $\gamma_{\text {eff }}$ values lie below $\gamma_{\text {eqv }}$ values for other combinations of aerosol types and land use categories.

We can only expect comparable uptake between ground and aerosol surfaces of mineral dust, soot, solid organic aerosol and SSA at high aerosol loadings in urban areas (e.g., $A=1400 \mu \mathrm{m}^{2} \mathrm{~m}^{-3}$, Beijing) and/or high mixing layers (e.g., $h=1.0 \mathrm{~km})$. Combined with the measured uptake coefficients which lie in the range of $1.0 \times 10^{-7}$ to $1.6 \times 10^{-4}$ for soot, $1.1 \times 10^{-5}$ to $3.0 \times 10^{-3}$ for liquid organic aerosols and $1.3 \times 10^{-6}$ to $1.0 \times 10^{-4}$ for SSA, we can expect high 

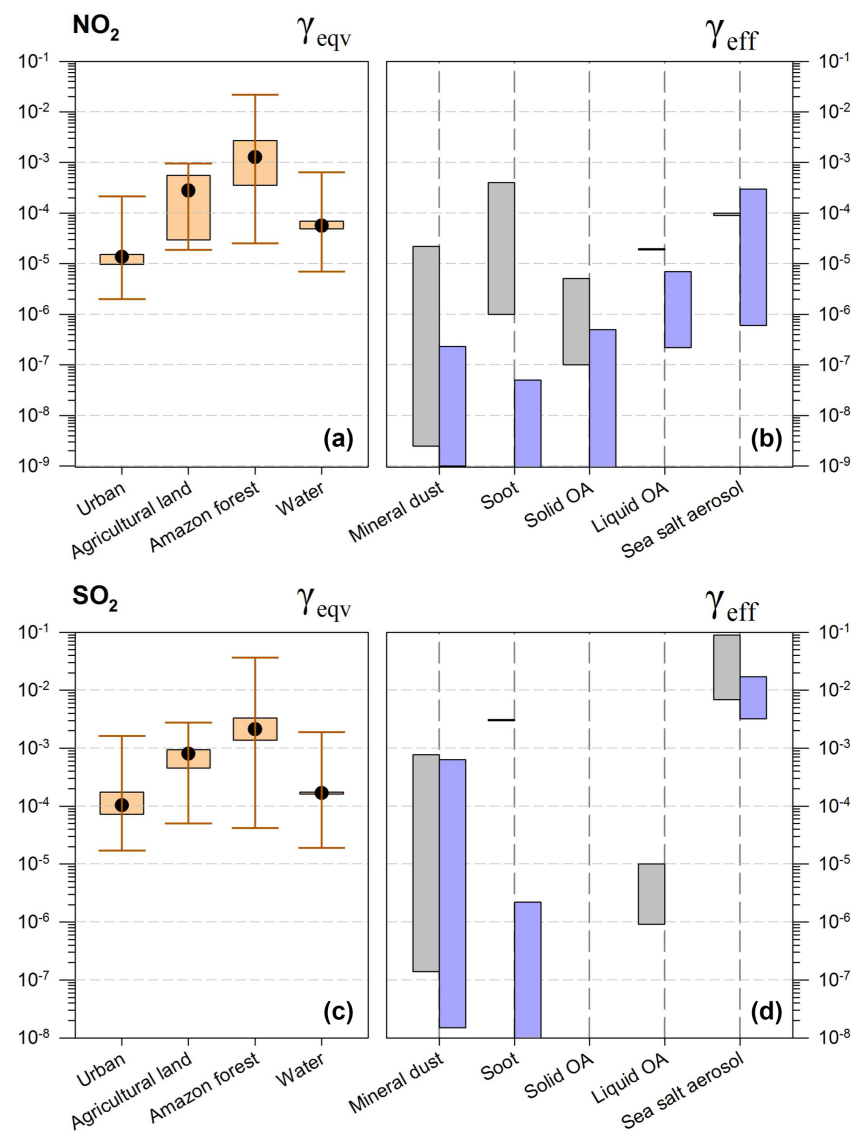

Figure 4. Uptake coefficients $\left(\gamma_{\mathrm{eqv}}, \mathbf{a}, \mathbf{c} ; \gamma_{\mathrm{eff}}, \mathbf{b}, \mathbf{d}\right)$ for $\mathrm{NO}_{2}$ and $\mathrm{SO}_{2}$ on different ground types and aerosols.

uptake fluxes of $\mathrm{O}_{3}$ on these three kinds of aerosols when the corresponding $\gamma_{\text {eff }}$ value is larger than $10^{-4}$ for ground surfaces other than urban.

Complexity comes from the organic aerosols, of which the phase state has a large impact on the uptake and is subject to the temperature, relative humidity and particle size (see Fig. 3) (Virtanen et al., 2010; Cheng et al., 2015). For liquid organic aerosols, the measured $\gamma_{\text {eff }}$ values show large variances from $10^{-5}$ to $10^{-3}$ and corresponding $\gamma_{\text {eqv }}$ values fall into this range, demonstrating that $\mathrm{O}_{3}$ uptake on aerosols is comparable to that on the ground. Thus, multiphase reactions of $\mathrm{O}_{3}$ on liquid organic aerosols should be included in atmospheric models. This is also consistent with the findings of Mu et al. (2018), which demonstrate the importance of the phase state of aerosols in multiphase reactions and the transport of polycyclic aromatic hydrocarbons to improve the model performances at both regional and global scales.

Shiraiwa et al. (2017) show the global map of the SOA (secondary organic aerosol) phase state at the Earth's surface. SOA in southern China, the Amazon forest and South Africa are mainly in the liquid phase within the PBL. For these regions, the comparable uptake fluxes for $\mathrm{O}_{3}$ on liquid organic aerosols compared with the dry deposition demonstrate the importance of aerosol uptake. Dry deposition is one of the major sinking pathways for $\mathrm{O}_{3}$ (Ganzeveld and Lelieveld, 1995). The uptakes of $\mathrm{O}_{3}$ by aerosols are expected to contribute comparable sink fluxes to dry deposition regionally. Inclusion of the $\mathrm{O}_{3}$ uptake by organic aerosols in these regions will increase the deposition rate of $\mathrm{O}_{3}$ on aerosols, affect its lifetime, and further affect the fate of $\mathrm{HO}_{x}$ and $\mathrm{NO}_{x}$ through chemical reactions in the gas phase.

\section{$3.2 \quad \mathrm{NO}_{2}$}

For $\mathrm{NO}_{2}, \gamma_{\text {eqv }}$ values are generally above the upper limit of $\gamma_{\text {eff }}$ in urban, agricultural and forest environments, as shown in Fig. 4, demonstrating that ground surfaces are of greater importance than aerosols. Overlaps are found for SSA on various land use types and also for liquid organic aerosols in the urban environment.

$\mathrm{NO}_{2}$ tends to deposit on the ground surface instead of on mineral dust particles, soot and solid organic aerosols. As reviewed in Tables A1-A3, the effective uptake coefficient of $\mathrm{NO}_{2}$ on these three kinds of aerosols are at magnitudes of $<10^{-6}$ under steady-state conditions. For $A$ values ranging from $46 \mu \mathrm{m}^{2} \mathrm{~cm}^{-3}$ (Amazon) to $1050 \mu \mathrm{m}^{2} \mathrm{~cm}^{-3}$ (Wangdu) and at a mixing height of $300 \mathrm{~m}, \gamma_{\text {eqv }}$ values of $\mathrm{NO}_{2}$ lie between $1.4 \times 10^{-5}$ and $1.3 \times 10^{-3}$, and are 1-3 orders of magnitude larger than $\gamma_{\text {eff }}$ on these three kinds of aerosols. Increasing the PBL mixing height and aerosol surface area may reduce $\gamma_{\text {eqv }}$ values by $\sim 1-2$ orders of magnitude, but they are still above the measured $\gamma_{\text {eff }}$ values at steady state.

The reactive uptake coefficients of $\mathrm{NO}_{2}$ by SSA were quantified in the range of $10^{-6}$ to $10^{-4}$, demonstrating the ability of ambient sea salt aerosols to take in chemical species like $\mathrm{NO}_{2}$ (Harrison and Collins, 1998; Yabushita et al., 2009; Ye et al., 2010). The high uptake coefficients observed for SSA $\left(6.0 \times 10^{-7}-3.0 \times 10^{-4}\right)$ are probably attributed to the reactions of $\mathrm{Cl}^{-}$with dissolved $\mathrm{NO}_{2}$ in the aqueous phase (Msibi et al., 1993; Harrison and Collins, 1998; Yabushita et al., 2009). The overlapped values of $\gamma_{\text {eqv }}$ and $\gamma_{\text {eff }}$ show that the $\mathrm{NO}_{2}$ uptake by SSA is comparable to the uptake by the land surface or water bodies in coastal areas; therefore, it should be taken into account in atmospheric models.

Another important process is the $\mathrm{NO}_{2}$ uptake on liquid organic aerosols $\left(\gamma_{\text {eff }}\right.$ in the range of $\left.2.2 \times 10^{-7}-7.0 \times 10^{-6}\right)$ in urban areas of high $A$. As shown in Fig. 4, the lower limit of $\gamma_{\text {eqv }}$ in urban is $\sim 2.2 \times 10^{-6}$, which lies within the range of $\gamma_{\text {eff. }}$. The uptake coefficients of $\mathrm{NO}_{2}$ on pure water are estimated to be around $10^{-7}-10^{-6}$, driven by low solubility and slow hydrolysis rates (Kleffmann et al., 1998; Gutzwiller et al., 2002; Ammann et al., 2005; Komiyama and Inoue, 1980). Harrison and Collins (1998) reported a high $\gamma_{\text {eff }}$ of 5.4 $5.8 \times 10^{-4}$ for $\mathrm{NO}_{2}$ uptake on ammonium sulfate aerosols at high relative humidity $(\mathrm{RH} ; \mathrm{RH}=50 \%, 85 \%)$. The presence of reactants such as inorganics of $\mathrm{HSO}_{3}^{-}$or phenolic compounds in aqueous aerosols can promote the uptake significantly via chemical reactions with dissolved $\mathrm{NO}_{2}$ to $10^{-5}$ 
$10^{-4}$ (Msibi et al., 1993; Lee and Tang, 1998; Spindler et al., 2003; Ammann et al., 2005; Yabushita et al., 2009; Su et al., 2008a; Cheng et al., 2016). Multiple measurements and modeling work have also pointed out that the high alkalinity of aqueous aerosols is key to promote the reactions and further increase the $\mathrm{NO}_{2}$ uptake rates (Ammann et al., 2005; Herrmann et al., 2015; Cheng et al., 2016). Therefore, the $\mathrm{NO}_{2}$ uptake on alkaline aqueous aerosols containing organic/inorganic reactants is competitive in the urban atmosphere, and should be addressed in detail in models. In the Amazon forest, where $A$ is too low $\left(46 \mu \mathrm{m}^{2} \mathrm{~cm}^{-3}\right)$, corresponding to a $\gamma_{\text {eqv }}$ value of the order of $10^{-3}$, even a high

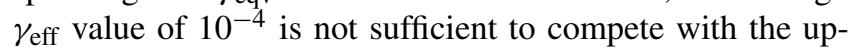
take by the ground surfaces.

In summary, the $\mathrm{NO}_{2}$ uptake coefficients on liquid aerosol droplets can vary by 3 orders of magnitude with aerosol composition $\left(10^{-7}-10^{-4}\right)$. On liquid organic aerosols and sea salt aerosols, the uptake can reach up to $10^{-6}-10^{-4}$ via chemical reactions (Abbatt and Waschewsky, 1998; Ammann et al., 2005; Yabushita et al., 2009), which is significantly larger than the uptake on pure water of $10^{-7}-10^{-6}$ (Lee and Tang, 1988; Kleffmann et al., 1998; Gutzwiller et al., 2002). For liquid ammonium sulfate aerosols, discrepancies with 2 orders of magnitude $\left(10^{-6}-10^{-4}\right)$ in $\gamma_{\text {eff }}$ values are found, although the reasons for this are currently unknown (Harrison and Collins, 1998; Tan et al., 2016). Considering these variances, aerosol components are important to parameterize the $\gamma_{\text {eff }}$ in atmospheric models.

\section{$3.3 \quad \mathrm{SO}_{2}$}

The calculated $\gamma_{\text {eqv }}$ values of $\mathrm{SO}_{2}$ vary between $1.0 \times 10^{-4}$ and $2.1 \times 10^{-3}$ for land surfaces and $1.7 \times 10^{-4}$ above water bodies under typical conditions. As shown in Fig. 4, the $\mathrm{SO}_{2}$ uptake by mineral dust is comparable to the ground uptake in urban areas, and under favorable conditions over agricultural land and water bodies. For soot, aerosol uptake is magnitudes lower than those on the ground ( $\gamma_{\text {eqv }} \geq \gamma_{\text {eff }}$ ); thus, this process is unimportant for $\mathrm{SO}_{2}$. For SSA, $\gamma_{\text {eff }}$ values of $3.2 \times 10^{-3}-1.7 \times 10^{-2}$ have been reported for $\mathrm{SO}_{2}$ at an aerosol $\mathrm{pH}$ of 5.4-6.6, which is high enough to compete with dry deposition over most environments (Gebel et al., 2000). Additional reactions of $\mathrm{SO}_{2}$ and $\mathrm{O}_{3}$ in alkaline solutions are found to promote the $\mathrm{SO}_{2}$ uptake and form sulfate on SSA at first stage (Laskin et al., 2003). However, aerosol acidification due to production of $\mathrm{H}^{+}$has been suggest to quickly suppress the oxidation process in the real world (Alexander et al., 2005). We suggest including both the $\mathrm{SO}_{2}$ uptake on SSA and the aerosol acidification process in models.

The extended range of $\gamma_{\text {eqv }}$ is $1.6 \times 10^{-5}-1.6 \times 10^{-3}$, $5.5 \times 10^{-5}-2.8 \times 10^{-3}$ and $1.9 \times 10^{-5}-1.9 \times 10^{-3}$ for urban areas, agricultural land and water bodies, respectively. The $\gamma_{\text {eff }}$ of mineral dust falls in this range under high aerosol loadings or high mixing heights. The wide range of $\gamma_{\text {eff }}$ values for mineral dust $\left(1.5 \times 10^{-8}\right.$ to $\left.6.3 \times 10^{-4}\right)$ is a big challenge re- garding its application in models, because it can be affected by the presence of oxidants, the phase state, the components of the tested dust and the use of surface area in calculation (Huss et al., 1982; Ullerstam et al., 2003; Li et al., 2006; Alexander et al., 2009; Zhang et al., 2018). We further discuss the $\mathrm{SO}_{2}$ uptake on mineral dust under different conditions in the following.

Under dry conditions (as reviewed in Table A1), $\gamma_{\text {eff }}$ values of the order of $10^{-7}-10^{-4}$ are measured (Goodman et al., 2001; Usher et al., 2002; Ullerstam et al., 2003; Adams et al., 2005; Li et al., 2006). IUPAC recommends an averaged value of $4 \times 10^{-5}$ for atmospheric modeling, based on measurements using airborne aerosols (Usher et al., 2002; Adams et al., 2005).

In environments with a high $\mathrm{RH}$, water can enhance or inhibit the uptake by affecting reactive sites, and this effect varies with experimental conditions (Huang et al., 2015; Zhang et al., 2018). Conversely, the uptake rate can be improved by several factors and/or aqueous chemical reactions, such as the presence of $\mathrm{O}_{3}, \mathrm{H}_{2} \mathrm{O}_{2}$ and transition metal ions (TMIs), which strongly depend on the aerosol pH (Jayne et al., 1990; Li et al., 2006; Cheng et al., 2016; Zhang et al., 2018). The initial $\gamma_{\text {eff }}$ value of $\mathrm{SO}_{2}$ on pure water can reach as high as $10^{-3}-0.1$, varying with $\mathrm{pH}$ (Gardner et al., 1987; Worsnop et al., 1989; Jayne et al., 1990; Ponche et al., 1993). Depending on aerosol $\mathrm{pH}$ and oxidant concentrations, the regimes of $\mathrm{SO}_{2}$ uptake and sulfate formation may transit from a TMI- or $\mathrm{H}_{2} \mathrm{O}_{2}$-dominated regime to a $\mathrm{NO}_{2}$ - or $\mathrm{O}_{3}$ dominated regime (Cheng et al., 2016). In this case, the $\mathrm{SO}_{2}$ uptake on aqueous aerosols is expected to play a dominant role over dry deposition under specific circumstances, such as haze events (He et al., 2014; Cheng et al., 2016), which should be quantified by combining in situ measurements and atmospheric modeling.

As shown in the examples in Table S4, several model

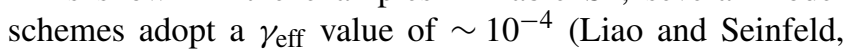
2005; K. Wang et al., 2012), around 1 order of magnitude higher than the measured values under low RH conditions (Usher et al., 2002; Ullerstam et al., 2003; Adams et al., 2005; Li et al., 2006). For example, in Liao and Seinfeld (2005), $\gamma_{\text {eff }}$ is $3.0 \times 10^{-4}$ for $\mathrm{RH}<50 \%$, and 0.1 for $\mathrm{RH}$ $\geq 50 \%$ (see Table S4 with references). Under low RH conditions, the uptake coefficient commonly used in models is based on the dry deposition measurement of $\mathrm{SO}_{2}$ on calcareous soils, cements and $\mathrm{Fe}_{2} \mathrm{O}_{3}$, rather than on laboratory measured $\gamma_{\text {eff }}$ values recommended by IUPAC. The reason for this divergence is unclear, and we are in favor of using the IUPAC recommended $\gamma_{\text {eff }}$ (e.g., Zhu et al., 2010, as shown in Table S4). The high uptake coefficient in models under high RH conditions is based on two assumptions: fast oxidation of $\mathrm{SO}_{2}$ by $\mathrm{O}_{3}$ in the aqueous phase, and high alkalinity in the dust aerosols. Thus, this $\gamma_{\text {eff }}$ value should be applied with the caveat that these prerequisites have been fulfilled, especially when extending it for other type of aerosols (Zheng et al., 2015). 

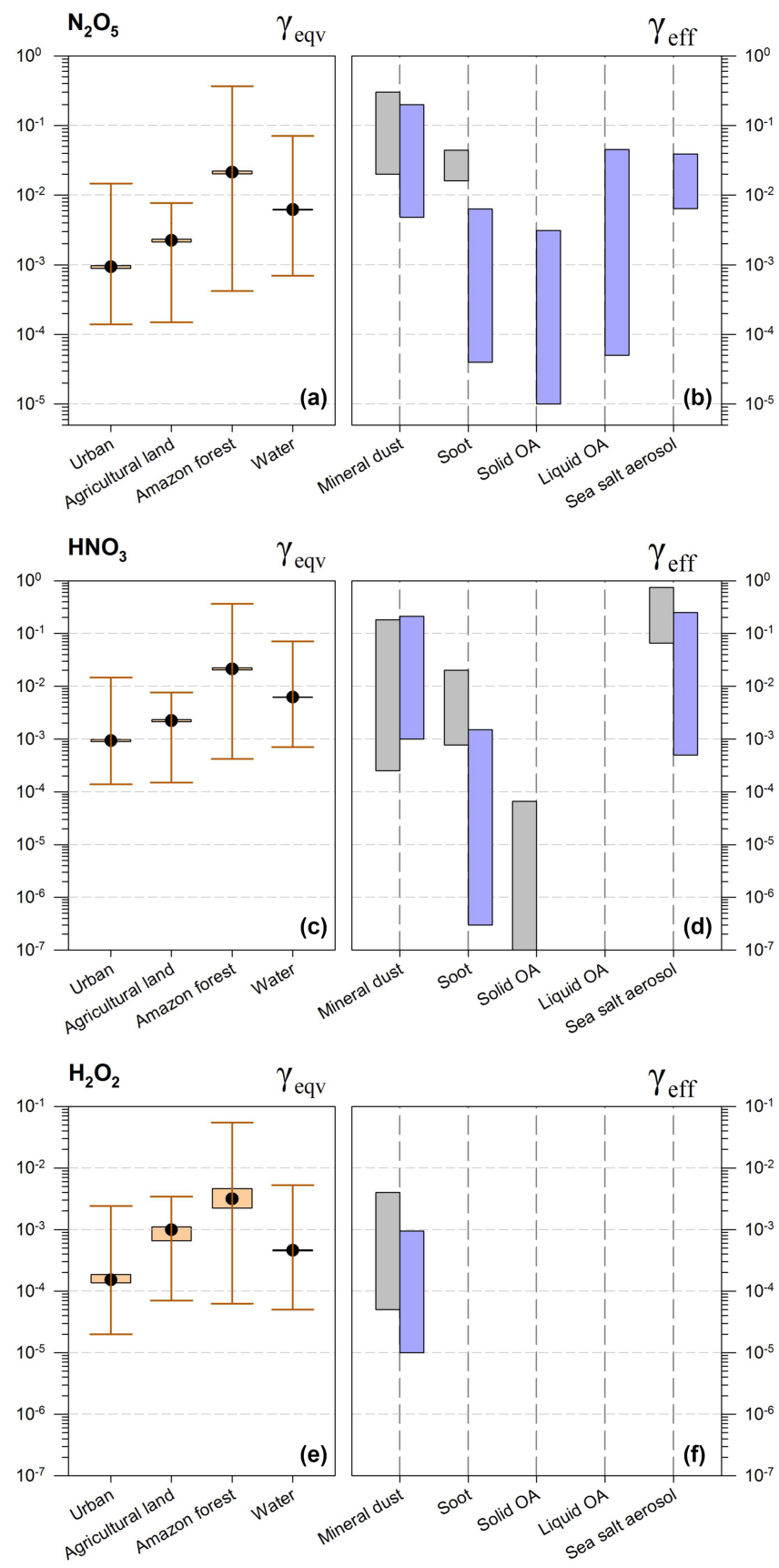

Figure 5. Uptake coefficients $\left(\gamma_{\mathrm{eqv}}, \mathbf{a}, \mathbf{c}, \mathbf{e} ; \gamma_{\mathrm{eff}}, \mathbf{b}, \mathbf{d}, \mathbf{f}\right)$ for $\mathrm{N}_{2} \mathrm{O}_{5}$, $\mathrm{HNO}_{3}$ and $\mathrm{H}_{2} \mathrm{O}_{2}$ on different ground types and aerosols.

\section{$3.4 \mathrm{~N}_{2} \mathrm{O}_{5}, \mathrm{HNO}_{3}$ and $\mathrm{H}_{2} \mathrm{O}_{2}$}

$\mathrm{N}_{2} \mathrm{O}_{5}, \mathrm{HNO}_{3}$ and $\mathrm{H}_{2} \mathrm{O}_{2}$ demonstrate their high uptake ability on atmospheric aerosols, as shown in Fig. 5. For $\mathrm{N}_{2} \mathrm{O}_{5}$, the similar or higher values of $\gamma_{\text {eff }}$ over $\gamma_{\text {eqv }}$ demonstrate that the multiphase uptake by all types of aerosols is as important as or even more important than dry deposition. The $\mathrm{N}_{2} \mathrm{O}_{5}$ uptake by aerosols has been widely included in models (Bauer et al., 2004; Liao and Seinfeld, 2005; K. Wang et al., 2012). The uptake of $\mathrm{HNO}_{3}$ and $\mathrm{H}_{2} \mathrm{O}_{2}$ by mineral dust and $\mathrm{HNO}_{3}$ by SSA are important given the overlap between $\gamma_{\text {eff }}$ and $\gamma_{\text {eqv }}$; thus, this uptake should also be characterized in atmospheric models in detail.

For $\mathrm{N}_{2} \mathrm{O}_{5}$, the measured uptake coefficients are $4.8 \times$ $10^{-3}-0.20$ for mineral dust, $4.0 \times 10^{-5}-6.3 \times 10^{-3}$ for soot and $6.4 \times 10^{-3}-3.9 \times 10^{-2}$ for SSA, which are comparable to or 1-2 orders of magnitude higher than the calculated $\gamma_{\text {eqv }}$ values of $9.3 \times 10^{-4}-2.1 \times 10^{-2}$ under typical conditions (details in Tables A1-A4). For other kinds of aqueous aerosols, e.g., ammonium sulfate aerosols with high $\mathrm{RH}, \mathrm{N}_{2} \mathrm{O}_{5}$ can also be taken up very efficiently with $\gamma_{\text {eff }}$ values of $10^{-3}$ $10^{-2}$ (Kane et al., 2001; Schötze and Herrman, 2002; Hallquist et al., 2003; Badger et al., 2006). The importance of $\mathrm{N}_{2} \mathrm{O}_{5}$ and $\mathrm{HNO}_{3}$ uptake by aerosols has been sufficiently addressed in previous studies (Evans and Jacob, 2005; Liao and Seinfeld, 2005; Stadtler et al., 2018). In current CTMs, $\gamma_{\text {eff }}$ of $\mathrm{N}_{2} \mathrm{O}_{5}$ is explicitly calculated as a function of temperature and $\mathrm{RH}$, for which the relation was determined from laboratory experiments (Kane et al., 2001; Bauer et al., 2004; Liao and Seinfeld, 2005).

The extended ranges of $\gamma_{\text {eqv }}$ for $\mathrm{HNO}_{3}$ is $1.5 \times 10^{-4}$ $1.5 \times 10^{-2}$ (urban), $1.5 \times 10^{-4}-7.7 \times 10^{-3}$ (agricultural land), $4.2 \times 10^{-4}-3.7 \times 10^{-1}$ (Amazon forest) and $7.0 \times 10^{-4}-7.0 \times$ $10^{-2}$ (water), which are within or below the range of $\gamma_{\text {eff }}$ for mineral dust and SSA. The higher $\gamma_{\text {eff }}$ of $1.0 \times 10^{-3}$ to 0.21 for mineral dust and of $5.0 \times 10^{-4}$ to 0.25 for SSA demonstrated the more important role of aerosol uptake than of the ground surfaces. The uptake of $\mathrm{HNO}_{3}$ on soot and solid organic aerosols appears to be less important. The $\mathrm{HNO}_{3}$ uptake on mineral dust has been implemented in current models with an uptake coefficient of 0.1 , or between $1.1 \times 10^{-3}$ and 0.2 , which is consistent with the range of experimentally determined $\gamma_{\text {eff }}$ values reviewed in this study (Liao and Seinfeld, 2005; K. Wang et al., 2012).

The study of the uptake of $\mathrm{H}_{2} \mathrm{O}_{2}$ by aerosols is rather limited compared with the other aforementioned trace gases. The reported $\gamma_{\text {eff }}$ values on dust and ambient aerosol samples suggest that aerosol uptake is more important than that by the ground surface. The measured uptake coefficients of $\mathrm{H}_{2} \mathrm{O}_{2}$ on mineral dust are in the range of $1.0 \times 10^{-5}-9.4 \times 10^{-4}$ and overlap with the calculated $\gamma_{\text {eqv }}$ of $1.5 \times 10^{-4}-3.0 \times 10^{-3}$ under typical conditions. Ambient aerosols collected in urban areas show similar $\gamma_{\text {eff }}$ values of $\mathrm{H}_{2} \mathrm{O}_{2}\left(8.1 \times 10^{-5}\right.$ $4.6 \times 10^{-4}$ ) to mineral dust (Wu et al., 2015). The aerosol chemistry of $\mathrm{H}_{2} \mathrm{O}_{2}$ in the troposphere is complex and unclear (Liang et al., 2013; Li et al., 2016). In some cases, a net emission of $\mathrm{H}_{2} \mathrm{O}_{2}$ from aerosol surfaces has been speculated instead of an uptake or adsorption as a result of $\mathrm{HO}_{x}$ radicals cycling (Liang et al., 2013; Li et al., 2016). Most models only parameterize the $\mathrm{H}_{2} \mathrm{O}_{2}$ uptake by dust particles (Dentener et al., 1996; K. Wang et al., 2012). The uptake by other aerosol types has not been considered due to limited experimental data. Thus, more laboratory kinetic measurements are needed. As ambient aerosol samples show a $\gamma_{\text {eff }}$ 
similar to that of dust particles (Wu et al., 2015; Pradhan et al., 2010ab; Zhou et al., 2016), we suggest adopting the $\gamma_{\text {eff }}$ of dust particles and applying it to all aerosol types before new kinetic data become available.

\section{Discussion}

In this section, we address several important issues based on the comparisons. The large variability found in the measured $\gamma_{\text {eff }}$ for $\mathrm{SO}_{2}$ and $\mathrm{NO}_{2}$ is discussed in Sect. 4.1. How to apply the measured $\gamma_{\text {eff }}$ in atmospheric models to represent the reactivity of heterogeneous reactions still remains an open question. Regarding this, we discuss the underlying important factors that should be taken into account in Sect. 4.2. Outlooks and the limitations of this work are provided in Sect. 4.3.

\subsection{Large variability of $\gamma_{\text {eff }}$ for $\mathrm{SO}_{2}$ and $\mathrm{NO}_{2}$}

Notably, there is a large variability in the reviewed $\gamma_{\text {eff }}$ of $\mathrm{SO}_{2}$ uptake by dust particles (as discussed in Sect. 3.2). For $\mathrm{SO}_{2}$ uptake by dust particles, differences of more than 3 orders of magnitude are found for its uptake by mineral dust $\left(10^{-8}-10^{-4}\right.$, steady state), which may be attributed to several factors such as the experimental particle substrates, co-existing oxidants $\left(\mathrm{O}_{3}, \mathrm{H}_{2} \mathrm{O}_{2}\right.$ and $\left.\mathrm{NO}_{2}\right), \mathrm{RH}$, measurement techniques and the surface area used in data processing (Ullerstam et al., 2003; Li et al., 2006; Huang et al., 2015). For example, a $\gamma_{\text {eff }}$ of $1.6 \times 10^{-4}$ was derived for $\mathrm{SO}_{2}$ uptake on $\mathrm{Al}_{2} \mathrm{O}_{3}$ powder (Usher et al., 2002). The uptake coefficient was reduced by 1 order of magnitude to $1.6-6.6 \times 10^{-5}$ using ambient aerosols of Chinese loess/Saharan dust (Usher et al., 2002; Ullerstam et al., 2003; Adams et al., 2005), indicating that the particle substrate is key in investigating $\mathrm{SO}_{2}$ uptake. Similarly, through cross-comparisons between the other different investigations shown in Table A1, we anticipate that the above factors can all contribute to this large discrepancy. As recommended by IUPAC, an uptake coefficient of $4 \times 10^{-5}$ based on airborne measurements is suggested for use in models under low RH conditions. For high RH, we suggest determining $\gamma_{\mathrm{eff}}$ using information on aerosol $\mathrm{pH}$ due to the high correlation between these factors, as illustrated in Sect. 3.3.

For $\mathrm{NO}_{2}$ uptake on liquid aerosol droplets, differences of 3 orders of magnitude are found $\left(10^{-7}-10^{-4}\right)$, which vary significantly with aerosol composition. On pure water, the uptake is measured at $10^{-7}-10^{-6}$ (Lee and Tang, 1988; Kleffmann et al., 1998; Gutzwiller et al., 2002). On liquid organic aerosols and sea salt aerosols, the uptake can be effectively accelerated to $10^{-6}-10^{-4}$ via multiphase reactions (Abbatt and Waschewsky, 1998; Ammann et al., 2005; Yabushita et al., 2009). For ammonium sulfate aerosols, large discrepancies of $10^{-6}-10^{-4}$ for the initial $\gamma_{\text {eff }}$ are found, although the reasons for this are currently unknown (Harrison and Collins,
1998; Tan et al., 2016). Based on the reviewed measurements, we suggest using a relatively high uptake coefficient $\left(\sim 10^{-4}\right)$ for aqueous aerosols containing reactants, and a lower value $\left(<10^{-6}\right)$ for other cases.

\subsection{Initial vs. steady state and geometric vs. BET}

Measurements of the effective uptake coefficients revealed the instantly fast uptake at the initial state and the gradual decline due to the saturation of surface reaction sites and loss of reactive substances (Hanisch and Crowley, 2003). The uptake at the initial state can be orders of magnitude faster than that at the steady state for aerosols (see Tables 1 and A1-A4). The timescale for reaching surface saturation/equilibrium is dependent on the reaction system. For a gas-aqueous particle surface, the timescale to establish equilibrium for the investigated species is less than $1 \mathrm{~s}$ (Seinfeld and Pandis, 2006, 554-557). For dust particles, it can take hours for complete saturation (Judeikis et al., 1978; Goodman et al., 2001). Fine particles with diameters $<10 \mu \mathrm{m}$ have lifetimes of several days in the atmosphere (Prospero, 1999; Lee et al., 2009). Thus, using uptake coefficients at steady state maybe more representative in models, unless we can assume that the uptake process is not limited by surface accommodation and reactions (like $\mathrm{HNO}_{3}$; Goodman et al., 2000), typically when the gas concentration is low enough that the surface passivation is negligible compared with the lifetime of aerosols in the atmosphere (Hanisch and Crowley, 2003). Gas uptake on fresh aerosols may reach or even surpass the level of the ground near emission sources. Using a uniform uptake coefficient in atmospheric models may not be enough to reflect the deactivation process of the multiphase gas uptake during aerosol aging, considering the large range of $\gamma_{\text {eff }}$ values varying with time.

In addition, the $\gamma_{\text {eff }}$ values are measured and reported based on the geometric surface and/or the BET surface. Differences of more than 3 orders of magnitude are derived depending on whether or not the pores within the microstructure of solid aerosol surface are considered (see Table A1). Using the same method to calculate the available surface area may reconcile these differences (Tang et al., 2017). In this study, $\gamma_{\text {eff }}$ values with a revised BET surface are generally used as the lower limit, and those using the geometric surface are used as the upper limit. Whether or not the BET area is used as a correction in the calculation of $\gamma_{\text {eff }}$ or not remains a discrepancy when applied in models (Hanisch and Crowley, 2001a, b; Underwood et al., 2001ab). This discrepancy from measurements may come from the differences in experimental samples (airborne particles vs. powder). To solve this issue, more studies on the reactive surface area for ambient aerosols are needed to guide the data processing and model parameterization. 


\subsection{Outlooks and limitations}

We can conclude that the phase state is a crucial factor influencing the uptake rates. The uptake rates of $\mathrm{O}_{3}$ and $\mathrm{NO}_{2}$ in liquid organic aerosols are 1-3 orders of magnitude higher than on solid/semi-solid surfaces. In regions with high $\mathrm{RH}$ conditions and sufficient sources of organic compounds (e.g., the Amazon forest and southern China), the gas uptake is anticipated to have a considerable effect on concentrations. The effect is yet to be evaluated in combination with further model simulations.

Measurement of uptake by ambient aerosols is crucial to reconcile laboratory experiments and modeling results, especially for gases that have undergone limited investigation (e.g., $\mathrm{H}_{2} \mathrm{O}_{2}$ ). Currently limited work has been undertaken to address the uptake of $\mathrm{H}_{2} \mathrm{O}_{2}$ by aerosol particles other than mineral dust (Liao and Seinfeld, 2005; Pradhan et al., 2010a, b; K. Wang et al., 2012; Zhou et al., 2016). Because ambient aerosol samples show a $\gamma_{\text {eff }}$ value comparable to that of dust particles, we recommend similar $\gamma_{\text {eff }}$ values of $1.0 \times 10^{-5}-9.4 \times 10^{-4}$ for $\mathrm{H}_{2} \mathrm{O}_{2}$ uptake by other types of aerosol, which will lead to a larger sink in the atmospheric budget of $\mathrm{H}_{2} \mathrm{O}_{2}$.

Considering the complexity of multiple factors affecting the uptake rates, such as temperature, $\mathrm{RH}$, gas concentration, aerosol $\mathrm{pH}$ and aerosol state (fresh or aged), establishing a look-up table for $\gamma_{\text {eff }}$ based on the available factors mentioned above should be a feasible way to implement the gas uptake processes in atmospheric models (Mu et al., 2018).

There are limitations to the comparisons conducted in this study. We use a unified thermal velocity $\left(300 \mathrm{~m} \mathrm{~s}^{-1}\right)$ for all gases, which will introduce positive biases of $+4 \%$ to $+30 \%$ for $\mathrm{O}_{3}, \mathrm{NO}_{2}, \mathrm{SO}_{2}, \mathrm{HNO}_{3}$ and $\mathrm{H}_{2} \mathrm{O}_{2}$, and a negative bias of $-24 \%$ for $\mathrm{N}_{2} \mathrm{O}_{5}$ in calculations of $\gamma_{\text {eqv }}$ at the same temperature. The ambient parameters to calculate the dry deposition velocities (temperature and radiation) refer to the standard meteorological database for construction in northern China (Zhang, 2004), which may introduce uncertainties for analyses of other areas. In addition, the variability of aerosol surface area in each environment can also contribute to the variability of $\gamma_{\mathrm{eqv}}$. We mainly focused on the uptake fluxes at room temperature $(\sim 298 \mathrm{~K})$. The gas uptakes at very low temperatures (e.g., in the polar region and stratosphere) are outside the scope of this study but should be further explored concerning its potentially large impact. The real ambient multiphase processes are much more complex than the laboratory measurements; nevertheless, they use airborne aerosols. Ambient online measurements of $\gamma_{\text {eff }}$ will favor the model parameterization and improve our understanding of the multiphase processes within the PBL in the real world (Li et al., 2019). Moreover, more gaseous and aerosol species such as VOCs and bioaerosols should also be investigated (Zhou et al., 1996; Wagner et al., 2002; Fried et al., 2003; Beck et al., 2013; Li et al., 2014, 2016; Ouyang et al., 2016; Liu et al., 2017; Meusel et al., 2017).

\section{Conclusions}

In this work, we investigated the relative importance of gas uptake fluxes on the ground and aerosols for six reactive trace gases $\left(\mathrm{O}_{3}, \mathrm{NO}_{2}, \mathrm{SO}_{2}, \mathrm{~N}_{2} \mathrm{O}_{5}, \mathrm{HNO}_{3}\right.$ and $\left.\mathrm{H}_{2} \mathrm{O}_{2}\right)$, various environments, aerosol types and mixing heights. The purpose of the study was to identify the aerosol uptake process, which is equally or more important than dry deposition on ground surfaces but has not been adequately addressed in models.

For efficient comparison, we derived a criterion, $\gamma_{\text {eqv }}$, to identify the dominant surface with respect to gas uptake. For investigated gas species, $\gamma_{\text {eqv }}$ values generally lie in the magnitude of $10^{-4}$, and can be extended to lower values in polluted areas and/or at low dry deposition velocities: $\gamma_{\text {eqv }}$ values lie in the range of $10^{-6}-10^{-4}$ in polluted urban environments and $10^{-4}-10^{-1}$ under pristine forest conditions. The effective uptake coefficient $\left(\gamma_{\text {eff }}\right)$ values derived from experiments are reviewed and compared with $\gamma_{\text {eqv }}$. Notably, the gas uptake by aerosols is comparable and should be considered in models when $\gamma_{\text {eff }}$ is equal to or higher than $\gamma_{\text {eqv }}$. In urban environments, aerosol uptake is important for all combinations of gases and aerosols, which is favored by the high particle surface densities. On the contrary, the contribution of aerosol uptake is minor compared with dry deposition for gases in the Amazon forest.

The aerosol uptake of the following gases can be as important as the dry deposition processes and should be considered in atmospheric models: $\mathrm{N}_{2} \mathrm{O}_{5}$ on all types of aerosols, $\mathrm{HNO}_{3}$ and $\mathrm{SO}_{2}$ on mineral dust and sea salt aerosols, $\mathrm{H}_{2} \mathrm{O}_{2}$ on mineral dust, $\mathrm{NO}_{2}$ on sea salt aerosols, and $\mathrm{O}_{3}$ on liquid organic aerosols ( $\gamma_{\text {eff }} \geq \gamma_{\text {eqv }}$, as shown in Table 2$)$. The gas uptake on mineral dust for most gases and sea salt aerosols' uptake of $\mathrm{SO}_{2}$ and $\mathrm{NO}_{2}$ have already been parameterized in a series of models. The processes of $\mathrm{H}_{2} \mathrm{O}_{2}$ uptake on mineral dust and $\mathrm{O}_{3}$ on liquid aerosols have unfortunately not received enough attention. For other combinations of gas species and aerosols, the ground tends to be the dominant surface rather than aerosols with respect to taking up trace gases within the PBL.

There are several indications from this work of processes that should be addressed in future measurements and model implementations:

a. It is indicated that the multiphase processes for $\mathrm{O}_{3}$ on liquid organic aerosols are underestimated in current atmospheric models. For regions with high RH conditions and the existence of organic aerosols in the liquid state such as southern China, the Amazon forest and South Africa, the multiphase uptakes of $\mathrm{O}_{3}$ by aerosols are expected to contribute comparable sinking fluxes to dry deposition. Compared with the relatively low uptakes on (semi-) solid organic aerosols, we can conclude that the phase state is a crucial factor influencing the uptake rates. 
Table 2. Gas uptake processes that are potentially important compared with dry deposition across various environments (marked using a $\sqrt{ }$ ).

\begin{tabular}{lccccc}
\hline Gases & Mineral dust & Soot & Solid organic aerosol & Liquid organic aerosol & Sea salt aerosol \\
\hline $\mathrm{O}_{3}$ & & & & $\sqrt{ }$ & \\
$\mathrm{NO}_{2}$ & & & & & $\sqrt{ }$ \\
$\mathrm{SO}_{2}$ & $\sqrt{ }$ & & $\sqrt{ }$ & $\sqrt{ }$ & $\sqrt{ }$ \\
$\mathrm{N}_{2} \mathrm{O}_{5}$ & $\sqrt{ }$ & $\sqrt{ }$ & $\sqrt{ }$ & $\sqrt{ }$ \\
$\mathrm{HNO}_{3}$ & $\sqrt{ }$ & & & & \\
$\mathrm{H}_{2} \mathrm{O}_{2}$ & $\sqrt{ }$ & & & & \\
\hline
\end{tabular}

b. Large uncertainties should be addressed for the comparison results of $\mathrm{SO}_{2}$ and $\mathrm{NO}_{2}$. There are more than 3 orders of magnitude of variances in $\gamma_{\text {eff }}$ for $\mathrm{SO}_{2}$ on mineral dust and $\mathrm{NO}_{2}$ on aqueous aerosols. Under low $\mathrm{RH}$ circumstances, dry deposition tends to dominate the gas uptake rather than aerosols. However, for cases under high RH condition, the contributions of aerosols should be cautiously determined with full consideration of the aerosol component, aerosol $\mathrm{pH}$ and so on.

c. $\mathrm{H}_{2} \mathrm{O}_{2}$ uptake on a variety of aerosols needs to be measured and evaluated. It is shown that the $\mathrm{H}_{2} \mathrm{O}_{2}$ uptake on dust is comparable or even more important than that by the ground surface $\left(\gamma_{\text {eff }} \geq \gamma_{\text {eqv }}\right)$. Measurements using ambient aerosols suggest that the uptake on aerosols other than mineral dust should be of a similar magnitude.

Data availability. All parameters used to calculate $V_{\mathrm{d}}$, the aerosol surface area densities $(A)$ and the laboratory measurements of $\gamma_{\mathrm{eff}}$ were derived from peer-reviewed literature or publicly available databases (as illustrated in the main text). 


\section{Appendix A}

Table A1. Aerosol uptake coefficients $\left(\gamma_{\text {eff }}\right)$ for reactive gases on mineral dust observed in laboratory experiments $(T=298 \pm 2 \mathrm{~K}$ if not specified otherwise).

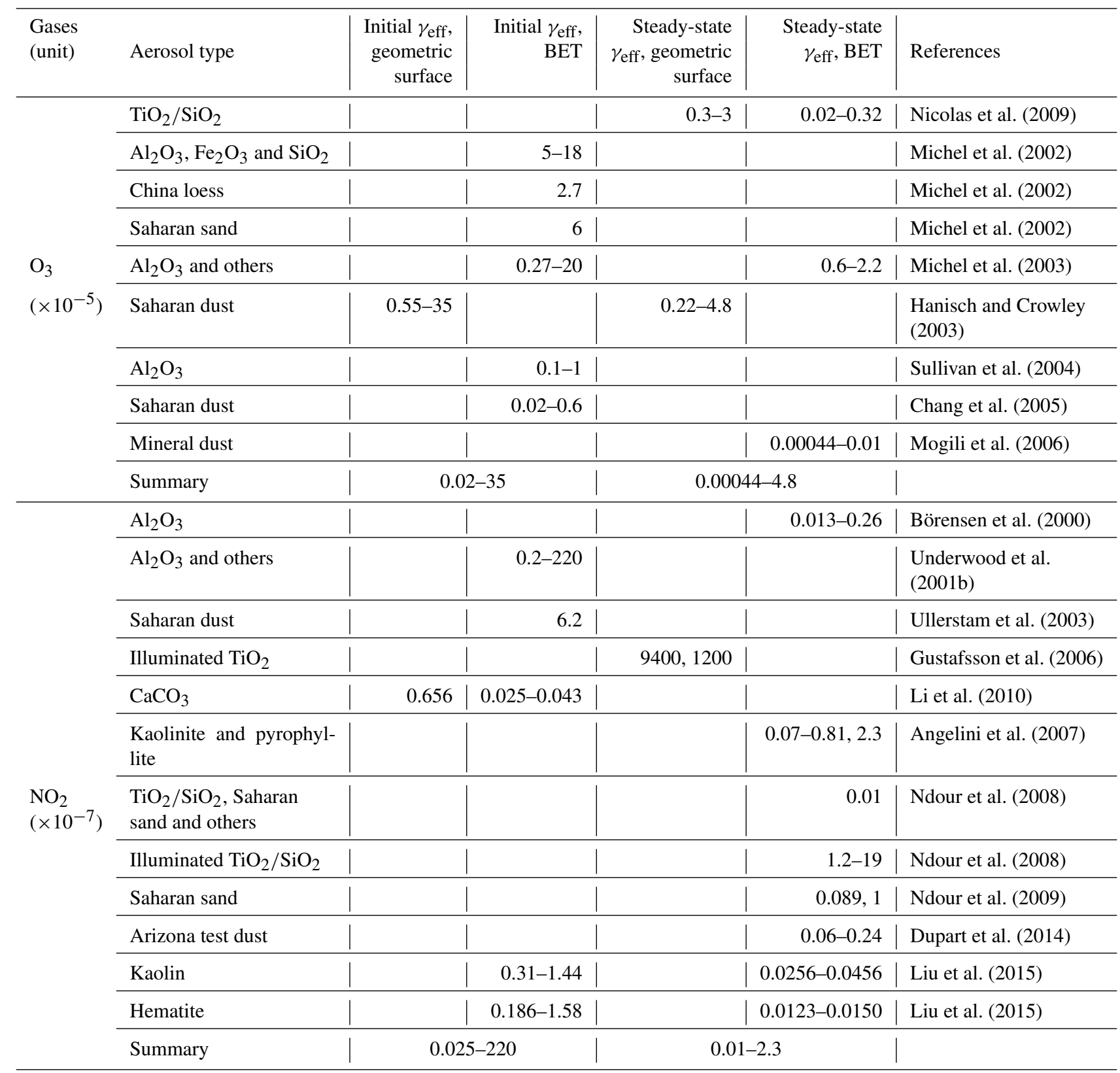


Table A1. Continued.

\begin{tabular}{|c|c|c|c|c|c|c|}
\hline $\begin{array}{l}\text { Gases } \\
\text { (unit) }\end{array}$ & Aerosol type & $\begin{array}{r}\text { Initial } \gamma_{\text {eff }} \\
\text { geometric } \\
\text { surface }\end{array}$ & $\begin{array}{r}\text { Initial } \gamma_{\text {eff }}, \\
\text { BET }\end{array}$ & $\begin{array}{r}\text { Steady-state } \\
\gamma_{\text {eff }}, \text { geometric } \\
\text { surface }\end{array}$ & $\begin{array}{r}\text { Steady-state } \\
\gamma_{\text {eff }}, \text { BET }\end{array}$ & References \\
\hline \multirow{17}{*}{$\begin{array}{l}\mathrm{SO}_{2} \\
\left(\times 10^{-5}\right)\end{array}$} & $\mathrm{CaCO}_{3}, \mathrm{O}_{3}$ & 77 & 0.014 & 8.1 & 0.0015 & Li et al. (2006) \\
\hline & Saharan dust and $\mathrm{O}_{3}$ & & & 390 & 0.05 & Ullerstam et al. (2002) \\
\hline & Saharan dust & & 1.6 & & & Ullerstam et al. (2003) \\
\hline & $\mathrm{Al}_{2} \mathrm{O}_{3}$ and $\mathrm{MgO}$ & & $9.5,26$ & & & Goodman et al. (2001) \\
\hline & $\mathrm{Al}_{2} \mathrm{O}_{3}$ and others & & $7.0-51$ & & & Usher et al. (2002) \\
\hline & Chinese loess & & 3 & & & Usher et al. (2002) \\
\hline & Saharan dust and $\mathrm{O}_{3}$ & & 6.6 & & & Adams et al. (2005) \\
\hline & $\mathrm{Al}_{2} \mathrm{O}_{3} \mathrm{Fe}_{2} \mathrm{O}_{3}$ and $\mathrm{MgO}$ & & $40,55,100$ & & & Judeikis et al. (1978) \\
\hline & $\mathrm{CaCO}_{3}$ powder & & 0.1 & & & Santschi and Rossi (2006) \\
\hline & $\mathrm{CaCO}_{3}$ and $\mathrm{O}_{3}$ & $43.5-65.6$ & $0.026-0.039$ & $0.54-22.1$ & $0.32-13.2$ & Zhang et al. (2018) \\
\hline & Asian mineral dust & & & $10.1-21.4$ & & Huang et al. (2015) \\
\hline & Tengger Desert dust & & & $22.9-39.0$ & & Huang et al. (2015) \\
\hline & Arizona test dust & & & $3.5-9.2$ & & Huang et al. (2015) \\
\hline & $\begin{array}{l}\text { Asian mineral dust, } \\
\mathrm{H}_{2} \mathrm{O}_{2}\end{array}$ & & & $39.1-54.5$ & & Huang et al. (2015) \\
\hline & $\begin{array}{l}\text { Tengger Desert dust, } \\
\mathrm{H}_{2} \mathrm{O}_{2}\end{array}$ & & & $37.2-63.1$ & & Huang et al. (2015) \\
\hline & $\begin{array}{l}\text { Arizona test dust, } \\
\mathrm{H}_{2} \mathrm{O}_{2}\end{array}$ & & & $4.6-13.1$ & & Huang et al. (2015) \\
\hline & Summary & 0.01 & -77 & 0.0015 & 63.1 & \\
\hline \multirow{17}{*}{$\begin{array}{l}\mathrm{N}_{2} \mathrm{O}_{5} \\
\left(\times 10^{-2}\right)\end{array}$} & Saharan sand & 30 & & 20 & & Karagulian et al. (2006) \\
\hline & Arizona test dust & 20 & & 11 & & Karagulian et al. (2006) \\
\hline & $\mathrm{CaCO}_{3}$ & 12 & & 2.1 & & Karagulian et al. (2006) \\
\hline & Kaolinite & $16-23$ & & $2.2-2.4$ & & Karagulian et al. (2006) \\
\hline & Saharan sand & 8 & & 1.3 & & Seisel et al. (2005) \\
\hline & Arizona dust & $0.5-1.3$ & & & & Wagner et al. (2008) \\
\hline & Saharan sand & 3.7 & & 3.7 & & Wagner et al. (2008) \\
\hline & Arizona dust & 2.2 & & 2.2 & & Wagner et al. (2008) \\
\hline & $\mathrm{CaCO}_{3}$ & 5.0 & & & & Wagner et al. (2008) \\
\hline & $\mathrm{CaCO}_{3}$ & & & $0.48-0.53$ & & Wagner et al. (2009) \\
\hline & $\mathrm{CaCO}_{3}$ & & & $1.13-1.94$ & & Wagner et al. (2009) \\
\hline & Arizona dust & & & $0.73-0.98$ & & Wagner et al. (2009) \\
\hline & Quartz & & & $0.86-0.45$ & & Wagner et al. (2009) \\
\hline & Saharan sand & & & & 2 & Tang et al. (2012) \\
\hline & Arizona dust & & & 0.63 & & Tang et al. (2014b) \\
\hline & Illite & & & $9.1,3.9$ & & Tang et al. (2014b) \\
\hline & Summary & & & 0.48 & & \\
\hline
\end{tabular}


Table A1. Continued.

\begin{tabular}{|c|c|c|c|c|c|c|}
\hline $\begin{array}{l}\text { Gases } \\
\text { (unit) }\end{array}$ & Aerosol type & $\begin{array}{r}\text { Initial } \gamma_{\text {eff }} \\
\text { geometric } \\
\text { surface }\end{array}$ & $\begin{array}{r}\text { Initial } \gamma_{\text {eff }}, \\
\text { BET }\end{array}$ & $\begin{array}{r}\text { Steady-state } \\
\gamma_{\text {eff }}, \text { geometric } \\
\text { surface }\end{array}$ & $\begin{array}{r}\text { Steady-state } \\
\gamma_{\text {eff }}, \text { BET }\end{array}$ & References \\
\hline \multirow{15}{*}{$\begin{array}{l}\mathrm{HNO}_{3} \\
\left(\times 10^{-2}\right)\end{array}$} & Mineral dust & & & $1.7-5.4$ & & Umann et al. (2005) \\
\hline & $\begin{array}{l}\text { Arizona dust, } \\
\mathrm{CaCO}_{3} \text { and } \mathrm{SiO}_{2}\end{array}$ & $2-11.3$ & & & & Vlasenko et al. (2006) \\
\hline & $\mathrm{CaCO}_{3}$ & & & $0.3-21$ & & Liu et al. (2008) \\
\hline & $\mathrm{CaCO}_{3}$ & $6.0-15$ & & & & Fenter et al. (1995) \\
\hline & $\mathrm{CaCO}_{3}$ & & 0.025 & & & Goodman et al. (2000) \\
\hline & $\begin{array}{l}\text { Saharan dust, } \\
\text { Arizona dust, } \\
\mathrm{CaCO}_{3}\end{array}$ & $11,6,10-18$ & & & & Hanisch and Crowley (2001a) \\
\hline & Saharan dust & 13.6 & & & & Hanisch and Crowley (2001b) \\
\hline & Chinese dust & 17.1 & & & & Hanisch and Crowley (2001b) \\
\hline & $\mathrm{Al}_{2} \mathrm{O}_{3}$ and others & & $0.002-0.0097$ & & & Underwood et al. (2001a) \\
\hline & $\mathrm{Al}_{2} \mathrm{O}_{3}$ and others & & $0.002-0.61$ & & & Underwood et al. (2001b) \\
\hline & $\mathrm{Fe}_{2} \mathrm{O}_{3}$ & & 0.0015 & & & Frinak et al. (2004) \\
\hline & $\begin{array}{l}\mathrm{Al}_{2} \mathrm{O}_{3} \text { and } \\
\text { Saharan dust }\end{array}$ & 13,11 & 13,11 & & & Seisel et al. (2004) \\
\hline & $\mathrm{CaCO}_{3}$ & & 0.2 & & & Johnson et al. (2005) \\
\hline & $\mathrm{CaCO}_{3}$ powder & & $0.7-30$ & & $0.07-0.2$ & Santschi and Rossi (2006) \\
\hline & Summary & 0.02 & -18 & $0.1-$ & & \\
\hline \multirow{15}{*}{$\begin{array}{l}\mathrm{H}_{2} \mathrm{O}_{2} \\
\left(\times 10^{-4}\right)\end{array}$} & Saharan sand & & & $6.20-9.42$ & & Pradhan et al. (2010b) \\
\hline & Gobi sand & & & $3.33-6.03$ & & Pradhan et al. (2010b) \\
\hline & $\mathrm{TiO}_{2}$ & & & 15,5 & & Pradhan et al. (2010a) \\
\hline & Arizona test dust & & $1.47-2.71$ & & $0.557-0.995$ & Zhou et al. (2016) ${ }^{\mathrm{a}}$ \\
\hline & $\begin{array}{l}\text { Inner Mongolia } \\
\text { desert dust }\end{array}$ & & $2.19-3.56$ & & $0.25-1.31$ & Zhou et al. $(2016)^{\mathrm{a}}$ \\
\hline & Xinjiang dust & & $0.446-0.734$ & & $0.377-0.431$ & Zhou et al. (2016) ${ }^{\mathrm{a}}$ \\
\hline & Arizona test dust & & 3.2 & & $0.095-0.185$ & El Zein et al. $(2014)^{b}$ \\
\hline & $\mathrm{TiO}_{2}$, dark & & $2.5-40$ & & & Romanias et al. (2012) \\
\hline & $\mathrm{TiO}_{2}, \mathrm{UV}$ & & & & 35 & Romanias et al. (2012) \\
\hline & $\mathrm{Al}_{2} \mathrm{O}_{3}$ & & 9.0 & & & Romanias et al. (2013) \\
\hline & $\mathrm{Fe}_{2} \mathrm{O}_{3}$ & & 8.6 & & & Romanias et al. (2013) \\
\hline & $\mathrm{SiO}_{2}$ & & & & $\begin{array}{r}0.000155 \\
0.000061\end{array}$ & Zhao et al. (2011) \\
\hline & $\mathrm{Al}_{2} \mathrm{O}_{3}$ & & & & $\begin{array}{r}0.00121 \\
0.00076\end{array}$ & Zhao et al. (2011) \\
\hline & $\begin{array}{l}\text { Ambient urban } \\
\text { aerosol }\end{array}$ & & & & $0.81-4.63$ & Wu et al. (2015) \\
\hline & Summary & & & $0.1-c$ & & \\
\hline
\end{tabular}

${ }^{\mathrm{a}} T=253-313 \mathrm{~K} ;{ }^{\mathrm{b}} T=268-320 \mathrm{~K}$. 
Table A2. Aerosol uptake coefficients $\left(\gamma_{\mathrm{eff}}\right)$ for reactive gases on soot observed in laboratory experiments $(T=298 \pm 2 \mathrm{~K}$ if not specified otherwise).

\begin{tabular}{|c|c|c|c|c|c|c|}
\hline $\begin{array}{l}\text { Gases } \\
\text { (unit) }\end{array}$ & Aerosol type & $\begin{array}{r}\text { Initial } \gamma_{\text {eff }}, \\
\text { geometric } \\
\text { surface }\end{array}$ & $\begin{array}{r}\text { Initial } \gamma_{\text {eff }}, \\
\text { BET }\end{array}$ & $\begin{array}{r}\text { Steady-state } \\
\gamma_{\text {eff }}, \text { geometric } \\
\text { surface }\end{array}$ & $\begin{array}{r}\text { Steady-state } \\
\gamma_{\text {eff }}, \text { BET }\end{array}$ & References \\
\hline \multirow{10}{*}{$\begin{array}{l}\mathrm{O}_{3} \\
\left(\times 10^{-5}\right)\end{array}$} & $\mathrm{BC}$ & 100 & & & & Rogaski et al. (1997) \\
\hline & Hydrocarbon soot & & & 16 & 0.5 & Longfellow et al. (2000) \\
\hline & Candle soot & & 13.9 & & 0.628 & Il'in (1991) \\
\hline & Degussa carbon black & & -100 & & -0.001 & Disselkamp et al. (2000) \\
\hline & Spark generated & & $22-330$ & & & Fendel et al. (1995) \\
\hline & Spark generated & & 0.12 & & 0.01 & Kamm et al. (1999) \\
\hline & $\begin{array}{l}\text { Kerosene and toluene } \\
\text { soot }\end{array}$ & & $18-38$ & & & Lelièvre et al. (2004b) \\
\hline & Charcoal & & $22-413$ & & $2.7-11.3$ & Stephens et al. (1986) \\
\hline & $\begin{array}{l}\text { Spark-generated soot } \\
\text { coated with } \\
\text { benzo[a]pyrene }\end{array}$ & & & $0.6-2$ & & Pöschl et al. (2001) \\
\hline & Summary & 13.9 & 100 & 0.0 & & \\
\hline \multirow{10}{*}{$\begin{array}{l}\mathrm{NO}_{2} \\
\left(\times 10^{-5}\right)\end{array}$} & Hydrocarbon soot & & $2.9-5.0$ & & $<0.001$ & Lelièvre et al. (2004a) \\
\hline & Spark generated & & $0.15-170$ & & $0.0016-0.61$ & Kirchner et al. (2000) \\
\hline & Hexane soot & $150-1840$ & $2.5-4.72$ & & $0.48-1.17$ & Al-Abadleh and Grassian (2000) \\
\hline & Spark generated & & & & $<=0.004$ & Saathoff et al. (2001) \\
\hline & Hexane soot, BC & & & & $0.0015-0.0024$ & Prince et al. (2002) \\
\hline & $\begin{array}{l}\text { Spark-generated, } \\
\text { commercial soot }\end{array}$ & $3-40$ & & & & Kalberer et al. (1996) \\
\hline & Ambient soot & 1100 & & 33 & & Ammann et al. (1998) \\
\hline & Commercial soot & & 0.1 & & $<0.001$ & Kleffmann et al. (1999) \\
\hline & Spark-generated & & $0.5-1.0$ & & & Arens et al. (2001) \\
\hline & Summary & 0.1 & & $<0$ & & \\
\hline \multirow{4}{*}{$\begin{array}{l}\mathrm{SO}_{2} \\
\left(\times 10^{-6}\right)\end{array}$} & $\mathrm{BC}$ & 3000 & & & & Rogaski et al. (1997) \\
\hline & Fresh BC and aged BC & & & & $0.00398,0.32$ & Xu et al. (2015) \\
\hline & $\mathrm{BC}$ and $\mathrm{O}_{3}$ & & & & 2.17 & Xu et al. (2015) \\
\hline & Summary & & & 0.00 & 2.17 & \\
\hline \multirow{4}{*}{$\begin{array}{l}\mathrm{N}_{2} \mathrm{O}_{5} \\
\left(\times 10^{-3}\right)\end{array}$} & Decane soot & 44 & & 5 & & Karagulian and Rossi (2007) \\
\hline & Spark generated & & & & $0.04-0.2$ & Saathoff et al. (2001) \\
\hline & Hydrocarbon soot & 16 & & 6.3 & & Longfellow et al. (2000) \\
\hline & Summary & & & 0.0 & & \\
\hline \multirow{5}{*}{$\begin{array}{l}\mathrm{HNO}_{3} \\
\left(\times 10^{-4}\right)\end{array}$} & Decane soot & 200 & & $4.6-5.2$ & & Salgado-Muñoz and Rossi (2002) \\
\hline & Spark generated & & & & 0.003 & Saathoff et al. (2001) \\
\hline & Hydrocarbon soot & & & 15 & 0.5 & Longfellow et al. (2000) \\
\hline & Spark generated & & $0.052-7.7$ & & $0.00098-0.019$ & Kirchner et al. (2000) \\
\hline & Summary & 7.7 & 200 & 0.00 & -15 & \\
\hline
\end{tabular}


Table A3. Aerosol uptake coefficients $\left(\gamma_{\text {eff }}\right)$ for reactive gases on organic aerosols observed in laboratory experiments $(T=298 \pm 2 \mathrm{~K}$ if not specified otherwise).

\begin{tabular}{|c|c|c|c|c|c|c|}
\hline $\begin{array}{l}\text { Gases } \\
\text { (unit) }\end{array}$ & Aerosol type & $\begin{array}{r}\text { Initial } \gamma_{\text {eff }}, \\
\text { geometric } \\
\text { surface }\end{array}$ & $\begin{array}{r}\text { Initial } \gamma_{\text {eff }}, \\
\text { BET }\end{array}$ & $\begin{array}{r}\text { Steady-state } \\
\gamma_{\text {eff }}, \begin{array}{r}\text { geometric } \\
\text { surface }\end{array}\end{array}$ & $\begin{array}{r}\text { Steady-state } \\
\gamma_{\text {eff }}, \text { BET }\end{array}$ & References \\
\hline \multirow{20}{*}{$\begin{array}{l}\mathrm{O}_{3} \\
\left(\times 10^{-5}\right)\end{array}$} & $\begin{array}{l}\text { Semi-solid protein } \\
\text { aerosol }\end{array}$ & 1.0 & & $<1.0$ & & Shiraiwa et al. (2011) \\
\hline & Shikimic acid film & & & $0.2-1.0$ & & Berkemeier et al. (2016) \\
\hline & Solid 1-hexadecene & & & $0.64-2.5$ & & Moise and Rudich (2000) ${ }^{\mathrm{a}}$ \\
\hline & Monolayer organic film & & & $17-27$ & & Moise and Rudich (2000) ${ }^{\mathrm{b}}$ \\
\hline & Solid-liquid oleic acid & & & $2-17$ & & Knopf et al. (2005) \\
\hline & $\begin{array}{l}\text { Solid-liquid oleic } \\
\text { acid (meat-cooking } \\
\text { aerosols) }\end{array}$ & & & $1.6-6.9$ & & Knopf et al. (2005) \\
\hline & $\begin{array}{l}\text { Liquid oleic acid } \\
\text { particle }\end{array}$ & 150 & & 5 & & Mendez et al. (2014) \\
\hline & $\begin{array}{l}\text { Liquid organic } \\
\text { compounds }\end{array}$ & & & $1.0-100$ & & de Gouw et al. (1998) \\
\hline & $\begin{array}{l}\text { Aqueous } \alpha \text {-pinene } \\
\text { aerosol }\end{array}$ & & & $300-750$ & & King et al. $(2008)^{\mathrm{c}}$ \\
\hline & $\begin{array}{l}\text { Aqueous fumarate } \\
\text { aerosol }\end{array}$ & & & 1.1 & & $\begin{array}{l}\text { King et al. } \\
(2008)^{c}\end{array}$ \\
\hline & $\begin{array}{l}\text { Aqueous benzoate } \\
\text { aerosol }\end{array}$ & & & 1.5 & & King et al. $(2008)^{\mathrm{c}}$ \\
\hline & $\begin{array}{l}\text { Liquid oleic acid } \\
\text { aerosol }\end{array}$ & 160 & & & & Morris et al. (2002) \\
\hline & Oleic acid aerosol & $55-90$ & & $20-100$ & & Sage et al. (2009) \\
\hline & Liquid 1-tridecene & & & $52-55$ & & Moise and Rudich (2000) ${ }^{\mathrm{d}}$ \\
\hline & Liquid 1-hexadecene & & & $32-38$ & & Moise and Rudich (2000) ${ }^{\mathrm{e}}$ \\
\hline & Liquid 1-hexadecane & & & 2.0 & & Moise and Rudich (2000) \\
\hline & Liquid oleic acid & & & 88 & & Hearn et al. (2005) \\
\hline & Liquid oleic acid & & & $40-72$ & & Knopf et al. (2005) \\
\hline & Liquid oleic acid & & & 730 & & Smith et al. (2002) \\
\hline & Summary & $\begin{array}{r}1.0 \text { fo } \\
55-160\end{array}$ & $\begin{array}{l}\text { solid, } \\
\text { or liquid }\end{array}$ & $\begin{array}{l}0.2-6.9 \mathrm{f} \\
1.1-300 \mathrm{f}\end{array}$ & solid, & \\
\hline
\end{tabular}


Table A3. Continued.

\begin{tabular}{|c|c|c|c|c|c|c|}
\hline $\begin{array}{l}\text { Gases } \\
\text { (unit) }\end{array}$ & Aerosol type & $\begin{array}{r}\text { Initial } \gamma_{\text {eff }} \\
\text { geometric } \\
\text { surface }\end{array}$ & $\begin{array}{r}\text { Initial } \gamma_{\text {eff }}, \\
\text { BET }\end{array}$ & $\begin{array}{r}\text { Steady-state } \\
\gamma_{\text {eff }}, \text { geometric } \\
\text { surface }\end{array}$ & $\begin{array}{r}\text { Steady-state } \\
\gamma_{\text {eff }}, \text { BET }\end{array}$ & References \\
\hline \multirow{17}{*}{$\begin{array}{l}\mathrm{NO}_{2} \\
\left(\times 10^{-6}\right)\end{array}$} & $\begin{array}{l}\text { Solid benzophenone, } \\
\text { catechol, anthracene } \\
\text { and } \\
\text { anthrarobin }\end{array}$ & $\begin{array}{c}0.07-1.26 \text { (dark), } \\
0.65-2.40 \text { (light) }\end{array}$ & & & & George et al. $(2005)^{\mathrm{f}}$ \\
\hline & $\begin{array}{l}\text { Solid benzophenone, } \\
\text { catechol, anthracene } \\
\text { and } \\
\text { anthrarobin }\end{array}$ & $\begin{array}{r}0.24-3.6 \text { (dark), } \\
1.3-5.1 \text { (light) }\end{array}$ & & & & George et al. $(2005)^{f}$ \\
\hline & $\begin{array}{l}\text { Solid } 1,2,10- \\
\text { trihydroxyanthracene }\end{array}$ & $0.7-2$ & & & & Arens et al. (2002) \\
\hline & $\begin{array}{l}\text { Solid } 1,2,10- \\
\text { trihydroxyanthracene }\end{array}$ & & & $<0.5$ & & Arens et al. (2002) \\
\hline & $\begin{array}{l}\text { Nitroguaiacol and a } \\
\text { mixture } \\
\text { of organics }\end{array}$ & 52,22 & & & & Knopf et al. (2011) \\
\hline & $\begin{array}{l}\text { Solid levoglucosan and } \\
\text { abietic acid }\end{array}$ & $<1.0$ & & & & Knopf et al. (2011) \\
\hline & $\begin{array}{l}\text { Solid pyrene, dark, } \\
\text { near-UV }\end{array}$ & & & $<0.1,3.5$ & & Brigante et al. (2008) \\
\hline & Solid pyrene & $<=1.0$ & & & & Gross et al. $(2008)^{\mathrm{g}}$ \\
\hline & SOA, pinene $/ \mathrm{O}_{3}$ & & & $<0.5$ & & Bröske et al. (2003) \\
\hline & $\begin{array}{l}\mathrm{SOA}, \text { limonene } / \mathrm{O}_{3}, \\
\text { catechol } / \mathrm{O}_{3}, \\
\text { limonene } / \mathrm{OH}, \\
\text { toluene / OH }\end{array}$ & & & $<1.5$ & & Bröske et al. (2003) \\
\hline & Humic acid, light & 20 & & & & Stemmler et al. (2006) \\
\hline & Humic acid, dark & & & $<0.1$ & & Stemmler et al. (2007) \\
\hline & $\begin{array}{l}\text { Humic acid, } \\
\text { illuminated }\end{array}$ & & & $2.6,3.7$ & & Stemmler et al. (2007) \\
\hline & $\begin{array}{l}\text { Catechol (surface- } \\
\text { absorbed) }+\mathrm{NaCl} / \\
\mathrm{NaBr} / \mathrm{NaF}\end{array}$ & & & & $3-7$ & $\begin{array}{l}\text { Woodill and Hinrichs } \\
\text { (2010) }\end{array}$ \\
\hline & $\begin{array}{l}\text { Gentisic acid, tannic } \\
\text { acid, UV/Vis light }\end{array}$ & & & & $0.22-0.88$ & Sosedova et al. (2011) \\
\hline & $\begin{array}{l}\text { Solution of guaiacol, } \\
\text { syringol and catechol }\end{array}$ & & & $\begin{array}{r}<0.1 \text { for } \mathrm{pH}<7, \\
10 \text { for } \mathrm{pH}>10\end{array}$ & & Ammann et al. (2005) \\
\hline & Summary & $\begin{array}{l}0.1-5.1 \text { for } \\
20 \text { for liq }\end{array}$ & $\begin{array}{l}\text { olid, } \\
\text { iid }\end{array}$ & $\begin{array}{l}<0.5 \text { for } \\
0.22-7 \text { for }\end{array}$ & $\begin{array}{l}\text { olid, } \\
\text { iquid }\end{array}$ & \\
\hline \multirow{3}{*}{$\begin{array}{l}\mathrm{SO}_{2} \\
\left(\times 10^{-6}\right)\end{array}$} & Liquid oleic acid & $0.92-6.44$ & & & & Shang et al. (2016) \\
\hline & $\begin{array}{l}\text { Liquid SOA by } \\
\text { limonene and } \mathrm{O}_{3}\end{array}$ & $10-50$ & & & & Ye et al. (2018) \\
\hline & Summary & $0.92-10$ for & iquid & Not avail & & \\
\hline
\end{tabular}


Table A3. Continued.

\begin{tabular}{|c|c|c|c|c|c|c|}
\hline $\begin{array}{l}\text { Gases } \\
\text { (unit) }\end{array}$ & Aerosol type & $\begin{array}{r}\text { Initial } \gamma_{\text {eff }}, \\
\text { geometric } \\
\text { surface }\end{array}$ & $\begin{array}{r}\text { Initial } \gamma_{\text {eff }}, \\
\text { BET }\end{array}$ & $\begin{array}{r}\text { Steady-state } \\
\gamma_{\text {eff }}, \text { geometric } \\
\text { surface }\end{array}$ & $\begin{array}{r}\text { Steady-state } \\
\gamma_{\text {eff }}, \text { BET }\end{array}$ & References \\
\hline \multirow{18}{*}{$\begin{array}{l}\mathrm{N}_{2} \mathrm{O}_{5} \\
\left(\times 10^{-3}\right)\end{array}$} & Solid malonic acid & & $<1.0$ & & & Thornton et al. (2003) \\
\hline & Solid azelaic acid & & 0.5 & & & Thornton et al. (2003) \\
\hline & Solid oxalic acid & & $<0.01$ & & & Griffiths et al. (2009) \\
\hline & Solid oxalic acid & & 3.1 & & & Griffiths et al. (2009) \\
\hline & Solid succinic acid & & $<0.6,<0.3$ & & & Griffiths et al. (2009) \\
\hline & Aqueous malonic acid & & $2.0,30$ & & & Thornton et al. (2003) \\
\hline & $\begin{array}{l}\text { Aqueous aerosols } \\
\text { coated with pinene } \\
\text { ozonolysis products }\end{array}$ & & $0.45-3.4$ & & & Folkers et al. (2003) \\
\hline & $\begin{array}{l}\text { Aqueous sulfate } \\
\text { particles coated with } \\
\text { monoterpene } \\
\text { ozonolysis products }\end{array}$ & & $11-45$ & & & Anttila et al. (2006) \\
\hline & Humic acid & & $0.1,0.3,1.0$ & & & Badger et al. (2006) \\
\hline & Malonic acid & & $8-16$ & & & Griffiths et al. (2009) \\
\hline & Succinic acid & & $5.2-9$ & & & Griffiths et al. (2009) \\
\hline & Glutaric acid & & $0.6-8$ & & & Griffiths et al. (2009) \\
\hline & Liquid oleic acid & & 0.054 & & & Gross et al. (2009) \\
\hline & Liquid diethyl sebacate & & 0.051 & & & Gross et al. (2009) \\
\hline & Liquid glycerol & & $0.645-0.814$ & & & Gross et al. (2009) \\
\hline & $\begin{array}{l}\text { Liquid conjugated } \\
\text { linoleic acid }\end{array}$ & & 0.046 & & & Gross et al. (2009) \\
\hline & Liquid linoleic acid & & 0.168 & & & Gross et al. (2009) \\
\hline & Summary & $\begin{array}{l}0.01-3.1 \\
0.05-45\end{array}$ & $\begin{array}{l}\text { for solid, } \\
\text { or liquid }\end{array}$ & Not ave & lable & \\
\hline \multirow{2}{*}{$\begin{array}{l}\mathrm{HNO}_{3} \\
\left(\times 10^{-5}\right)\end{array}$} & Solid pyrene & $\leq 6.6$ & & & & Gross et al. (2008) \\
\hline & Summary & \multicolumn{2}{|c|}{$\leq 6.6$ for solid } & \multicolumn{2}{|c|}{ Not available } & \\
\hline
\end{tabular}

${ }^{\mathrm{a}} T=272 \mathrm{~K} ;{ }^{\mathrm{b}} T=219-298 \mathrm{~K} ;{ }^{\mathrm{c}} T=293 \mathrm{~K} ;{ }^{\mathrm{d}} T=272-298 \mathrm{~K} ;{ }^{\mathrm{e}} T=283-298 \mathrm{~K} ;{ }^{\mathrm{f}} T=278-308 \mathrm{~K} ;{ }^{\mathrm{g}} T=293-297 \mathrm{~K}$. 
Table A4. Aerosol uptake coefficients ( $\left.\gamma_{\text {eff }}\right)$ for reactive gases on sea salt aerosols observed in laboratory experiments $(T=298 \pm 2 \mathrm{~K}$ if not specified otherwise).

\begin{tabular}{|c|c|c|c|c|c|c|}
\hline $\begin{array}{l}\text { Gases } \\
\text { (unit) }\end{array}$ & Aerosol type & $\begin{array}{r}\text { Initial } \gamma_{\text {eff }} \text {, } \\
\text { geometric } \\
\text { surface }\end{array}$ & $\begin{array}{r}\text { Initial } \gamma_{\text {eff }}, \\
\text { BET }\end{array}$ & $\begin{array}{r}\text { Steady-state } \\
\gamma_{\text {eff }} \text {, geometric } \\
\text { surface }\end{array}$ & $\begin{array}{r}\text { Steady-state } \\
\gamma_{\text {eff }}, \text { BET }\end{array}$ & References \\
\hline \multirow{6}{*}{$\begin{array}{l}\mathrm{O}_{3} \\
\left(\times 10^{-3}\right)\end{array}$} & Synthetic sea salt & $1.0-10$ & & & & Mochida et al. (2000) \\
\hline & Natural sea salt & 0.97 & & & & Mochida et al. (2000) \\
\hline & $\mathrm{NaCl}$ & & & & 0.0013 & Il'in et al. $(1991)^{\mathrm{a}}$ \\
\hline & Deliquesced $\mathrm{NaCl}$ & & & $<0.1$ & & Abbatt and Waschewsky (1998) \\
\hline & $\mathrm{NaCl} / \mathrm{Fe}_{2} \mathrm{O}_{3}$ & & $1.3,33-36$ & & & Sadanaga et al. (2001) \\
\hline & Summary & \multicolumn{2}{|c|}{$1.0-36$} & \multicolumn{2}{|c|}{$0.0013-0.1$} & \\
\hline \multirow{7}{*}{$\begin{array}{l}\mathrm{NO}_{2} \\
\left(\times 10^{-4}\right)\end{array}$} & Deliquesced $\mathrm{NaCl}$ & $<1.0$ & & & & Abbatt and Waschewsky (1998) \\
\hline & Deliquesced $\mathrm{NaCl}$ & & & $2.8-3.7$ & & Harrison and Collins $(1998)^{\mathrm{b}}$ \\
\hline & Aqueous $\mathrm{NaCl}$ & 1.0 & & & & Yabushita et al. (2009) \\
\hline & Chinese sea salt & & & & 0.00551 & Ye et al. (2010) \\
\hline & Chinese sea salt & & & & 0.0126 & Ye et al. (2010) \\
\hline & $\mathrm{NaCl}$ & & & & 0.6 & Vogt et al. (1994) \\
\hline & Summary & \multicolumn{2}{|c|}{1.0} & \multicolumn{2}{|c|}{$0.006-3.0$} & \\
\hline \multirow{2}{*}{$\begin{array}{l}\mathrm{SO}_{2} \\
\left(\times 10^{-3}\right)\end{array}$} & Synthetic sea salt & $6.0-90$ & & $3.2-17$ & & Gebel et al. (2000) \\
\hline & Summary & \multicolumn{2}{|c|}{$6.0-90$} & \multicolumn{2}{|c|}{$3.2-17$} & \\
\hline \multirow{16}{*}{$\begin{array}{l}\mathrm{N}_{2} \mathrm{O}_{5} \\
\left(\times 10^{-2}\right)\end{array}$} & $\mathrm{NaCl}$ & & & & 3.2 & Behnke et al. (1997) \\
\hline & $\mathrm{NaCl}$ & & & & 0.64 & Stewart et al. (2004) \\
\hline & $\mathrm{NaCl}$ & & & & 0.9 & Stewart et al. (2004) \\
\hline & $\mathrm{NaCl}$ & & & & 1.04 & Stewart et al. (2004) \\
\hline & $\mathrm{NaCl}$ & & & & 0.078 & Stewart et al. (2004) \\
\hline & Sea salt & & & & 1.6 & Stewart et al. (2004) \\
\hline & Sea salt & & & & 2.8 & Stewart et al. (2004) \\
\hline & Sea salt & & & & 1.3 & Stewart et al. (2004) \\
\hline & Sea salt & & & & 3.1 & Stewart et al. (2004) \\
\hline & Synthetic sea salt & & & & 2.2 & Thornton and Abbatt (2005) \\
\hline & Synthetic sea salt & & & & 3.0 & Thornton and Abbatt (2005) \\
\hline & Synthetic sea salt & & & & 2.4 & Thornton and Abbatt (2005) \\
\hline & $\mathrm{NaCl}$ & & & & 1.8 & Schweitzer et al. $(1998)^{\mathrm{c}}$ \\
\hline & $\mathrm{NaCl}$ & & & & $1.4-3.9$ & George et al. (1994) \\
\hline & Synthetic sea salt & & & 0.29 & & Hoffman et al. (2003) \\
\hline & Summary & Not a & iilable & 0.64 & & \\
\hline
\end{tabular}


Table A4. Continued.

\begin{tabular}{|c|c|c|c|c|c|c|}
\hline $\begin{array}{l}\text { Gases } \\
\text { (unit) }\end{array}$ & Aerosol type & $\begin{array}{r}\text { Initial } \gamma_{\text {eff }} \\
\text { geometric } \\
\text { surface }\end{array}$ & $\begin{array}{r}\text { Initial } \gamma_{\mathrm{eff}}, \\
\mathrm{BET}\end{array}$ & $\begin{array}{r}\text { Steady-state } \\
\gamma_{\text {eff }}, \text { geometric } \\
\text { surface }\end{array}$ & $\begin{array}{r}\text { Steady-state } \\
\gamma_{\text {eff }}, \text { BET }\end{array}$ & References \\
\hline \multirow{11}{*}{$\begin{array}{l}\mathrm{HNO}_{3} \\
\left(\times 10^{-2}\right)\end{array}$} & Deliquesced sea salt & 50 & & & & Guimbaud et al. (2002) \\
\hline & Synthetic sea salt & $6.6-75$ & & $3.0-25$ & & $\begin{array}{l}\text { De Haan and Finlayson-Pitts } \\
\text { (1997) }\end{array}$ \\
\hline & $\begin{array}{l}\text { Deliquesced } \mathrm{NaCl} \text {, } \\
100 \mathrm{~nm} \text { size }\end{array}$ & 0.49 & & & & Tolocka et al. (2004) \\
\hline & Deliquesced $\mathrm{NaCl}$ & 15 & & & & Saul et al. (2006) \\
\hline & Deliquesced $\mathrm{NaCl}$ & $21-11$ & & & & Liu et al. (2007) \\
\hline & $\mathrm{NaCl} / \mathrm{MgCl} 2$ & $25-12$ & & & & Liu et al. (2007) \\
\hline & Sea salt & $27-12$ & & & & Liu et al. (2007) \\
\hline & Deliquesced $\mathrm{NaCl}$ & 20 & & & & Abbatt and Waschewsky (1998) \\
\hline & Deliquesced $\mathrm{NaCl}$ & 50 & & & & Stemmler et al. (2008) \\
\hline & Synthetic sea salt & & & $0.04-0.065$ & & Hoffman et al. (2003) \\
\hline & Summary & \multicolumn{2}{|c|}{$6.6-75$} & \multicolumn{2}{|c|}{$0.05-25$} & \\
\hline
\end{tabular}

${ }^{\mathrm{a}} T=235-299 \mathrm{~K} ;{ }^{\mathrm{b}} T=279 \mathrm{~K} ;{ }^{\mathrm{c}} T=262-278 \mathrm{~K}$. 
Supplement. The supplement related to this article is available online at: https://doi.org/10.5194/acp-19-10981-2019-supplement.

Author contributions. HS and YC designed the research. ML performed the research with input from HS, YC and NM. UP and GL discussed the results. ML, HS and YC wrote the paper with input from all co-authors.

Competing interests. The authors declare that they have no conflict of interest.

Acknowledgements. We acknowledge the National Natural Science Foundation of China (grant no. 91644218), the National Key Research and Development Program of China (grant no 2017YFC0210104) and the Guangd ong Innovative and Entrepreneurial Research Team Program (grant no 2016ZT06N263). This work was supported by the Max Planck Society (MPG). Yafang Cheng also acknowledges the Minerva Program of the MaxPlanck-Gesellschaft.

Financial support. This research has been supported by the National Natural Science Foundation of China (grant no. 91644218), the National Key Research and Development Program of China (grant no. 2017YFC0210104), the Guangdong Innovative and Entrepreneurial Research Team Program (grant no. 2016ZT06N263) and the Max-Planck-Gesellschaft (Minerva Program).

The article processing charges for this open-access publication were covered by the Max Planck Society.

Review statement. This paper was edited by Andreas Hofzumahaus and reviewed by Mingjin Tang and one anonymous referee.

\section{References}

Abbatt, J. P. D. and Waschewsky, G. C. G.: Heterogeneous Interactions of $\mathrm{HOBr}, \mathrm{HNO}_{3}, \mathrm{O}_{3}$, and $\mathrm{NO}_{2}$ with Deliquescent $\mathrm{NaCl}$ Aerosols at Room Temperature, J. Phys. Chem. A, 102, 37193725, https://doi.org/10.1021/jp980932d, 1998.

Abbatt, J. P. D., Lee, A. K. Y., and Thornton, J. A.: Quantifying trace gas uptake to tropospheric aerosol: recent advances and remaining challenges, Chem. Soc. Rev., 41, 6555-6581, https://doi.org/10.1039/C2CS35052A, 2012.

Adams, J. W., Rodriguez, D., and Cox, R. A.: The uptake of $\mathrm{SO}_{2}$ on Saharan dust: a flow tube study, Atmos. Chem. Phys., 5, 26792689, https://doi.org/10.5194/acp-5-2679-2005, 2005.

Al-Abadleh, H. A. and Grassian, V. H.: Heterogeneous Reaction of $\mathrm{NO}_{2}$ on Hexane Soot: A Knudsen Cell and FT-IR Study, J. Phys. Chem. A, 104, 11926-11933, https://doi.org/10.1021/jp002918i, 2000.

Alexander, B., Park, R. J., Jacob, D. J., Li, Q. B., Yantosca, R. M., Savarino, J., Lee, C. C. W., and Thiemens,
M. H.: Sulfate formation in sea-salt aerosols: Constraints from oxygen isotopes, J. Geophys. Res.-Atmos., 110, D10307, https://doi.org/10.1029/2004JD005659, 2005.

Alexander, B., Park, R. J., Jacob, D. J., and Gong, S.: Transition metal-catalyzed oxidation of atmospheric sulfur: Global implications for the sulfur budget, J. Geophys. Res.-Atmos., 114, D02309, https://doi.org/10.1029/2008JD010486, 2009.

Ammann, M. and Pöschl, U.: Kinetic model framework for aerosol and cloud surface chemistry and gas-particle interactions - Part 2: Exemplary practical applications and numerical simulations, Atmos. Chem. Phys., 7, 6025-6045, https://doi.org/10.5194/acp7-6025-2007, 2007.

Ammann, M., Kalberer, M., Jost, D. T., Tobler, L., Rössler, E., Piguet, D., Gäggeler, H. W., and Baltensperger, U.: Heterogeneous production of nitrous acid on soot in polluted air masses, Nature, 395, 157-160, https://doi.org/10.1038/25965, 1998.

Ammann, M., Rössler, E., Strekowski, R., and George, C.: Nitrogen dioxide multiphase chemistry: Uptake kinetics on aqueous solutions containing phenolic compounds, Phys. Chem. Chem. Phys., 7, 2513-2518, https://doi.org/10.1039/B501808K, 2005.

Ammann, M., Cox, R. A., Crowley, J. N., Jenkin, M. E., Mellouki, A., Rossi, M. J., Troe, J., and Wallington, T. J.: Evaluated kinetic and photochemical data for atmospheric chemistry: Volume VI - heterogeneous reactions with liquid substrates, Atmos. Chem. Phys., 13, 8045-8228, https://doi.org/10.5194/acp13-8045-2013, 2013.

Andreae, M. O.: A New Look at Aging Aerosols, Science, 326, 1493-1494, https://doi.org/10.1126/science.1183158, 2009.

Andreae, M. O., Acevedo, O. C., Araùjo, A., Artaxo, P., Barbosa, C. G. G., Barbosa, H. M. J., Brito, J., Carbone, S., Chi, X., Cintra, B. B. L., da Silva, N. F., Dias, N. L., Dias-Júnior, C. Q., Ditas, F., Ditz, R., Godoi, A. F. L., Godoi, R. H. M., Heimann, M., Hoffmann, T., Kesselmeier, J., Könemann, T., Krüger, M. L., Lavric, J. V., Manzi, A. O., Lopes, A. P., Martins, D. L., Mikhailov, E. F., Moran-Zuloaga, D., Nelson, B. W., Nölscher, A. C., Santos Nogueira, D., Piedade, M. T. F., Pöhlker, C., Pöschl, U., Quesada, C. A., Rizzo, L. V., Ro, C.-U., Ruckteschler, N., Sá, L. D. A., de Oliveira Sá, M., Sales, C. B., dos Santos, R. M. N., Saturno, J., Schöngart, J., Sörgel, M., de Souza, C. M., de Souza, R. A. F., Su, H., Targhetta, N., Tóta, J., Trebs, I., Trumbore, S., van Eijck, A., Walter, D., Wang, Z., Weber, B., Williams, J., Winderlich, J., Wittmann, F., Wolff, S., and Yáñez-Serrano, A. M.: The Amazon Tall Tower Observatory (ATTO): overview of pilot measurements on ecosystem ecology, meteorology, trace gases, and aerosols, Atmos. Chem. Phys., 15, 10723-10776, https://doi.org/10.5194/acp-15-10723-2015, 2015.

Angelini, M. M., Garrard, R. J., Rosen, S. J., and Hinrichs, R. Z.: Heterogeneous Reactions of Gaseous $\mathrm{HNO}_{3}$ and $\mathrm{NO}_{2}$ on the Clay Minerals Kaolinite and Pyrophyllite, J. Phys. Chem. A, 111, 3326-3335, https://doi.org/10.1021/jp0672656, 2007.

Anttila, T., Kiendler-Scharr, A., Tillmann, R., and Mentel, T. F.: On the Reactive Uptake of Gaseous Compounds by OrganicCoated Aqueous Aerosols:? Theoretical Analysis and Application to the Heterogeneous Hydrolysis of $\mathrm{N}_{2} \mathrm{O}_{5}$, J. Phys. Chem. A, 110, 10435-10443, https://doi.org/10.1021/jp062403c, 2006.

Arens, F., Gutzwiller, L., Baltensperger, U., Gäggeler, H. W., and Ammann, M.: Heterogeneous Reaction of $\mathrm{NO}_{2}$ on Diesel Soot Particles, Environ. Sci. Technol., 35, 2191-2199, https://doi.org/10.1021/es000207s, 2001. 
Ashmore M. R.: Assessing the future global impacts of ozone on vegetation, Plant Cell Environ., 28, 949-964, https://doi.org/10.1111/j.1365-3040.2005.01341.x, 2005.

Badger, C. L., Griffiths, P. T., George, I., Abbatt, J. P. D., and Cox, R. A.: Reactive Uptake of $\mathrm{N}_{2} \mathrm{O}_{5}$ by Aerosol Particles Containing Mixtures of Humic Acid and Ammonium Sulfate, J. Phys. Chem. A, 110, 6986-6994, https://doi.org/10.1021/jp0562678, 2006.

Bauer, S. E., Balkanski, Y., Schulz, M., Hauglustaine, D. A., and Dentener, F.: Global modeling of heterogeneous chemistry on mineral aerosol surfaces: Influence on tropospheric ozone chemistry and comparison to observations, J. Geophys. Res.-Atmos., 109, D02304, https://doi.org/10.1029/2003JD003868, 2004.

Beck, I., Jochner, S., Gilles, S., McIntyre, M., Buters, J. T. M., Schmidt-Weber, C., Behrendt, H., Ring, J., Menzel, A., and Traidl-Hoffmann, C.: High Environmental Ozone Levels Lead to Enhanced Allergenicity of Birch Pollen, PLOS ONE, 8, e80147, https://doi.org/10.1371/journal.pone.0080147, 2013.

Behnke, W., George, C., Scheer, V., and Zetzsch, C.: Production and decay of $\mathrm{ClNO}_{2}$ from the reaction of gaseous $\mathrm{N}_{2} \mathrm{O}_{5}$ with $\mathrm{NaCl}$ solution: Bulk and aerosol experiments, J. Geophys. Res.Atmos., 102, 3795-3804, https://doi.org/10.1029/96JD03057, 1997.

Berkemeier, T., Steimer, S. S., Krieger, U. K., Peter, T., Poschl, U., Ammann, M., and Shiraiwa, M.: Ozone uptake on glassy, semi-solid and liquid organic matter and the role of reactive oxygen intermediates in atmospheric aerosol chemistry, Phys. Chem. Chem Phys., 18, 12662-12674, https://doi.org/10.1039/C6CP00634E, 2016.

Börensen, C., Kirchner, U., Scheer, V., Vogt, R., and Zellner, R.: Mechanism and Kinetics of the Reactions of $\mathrm{NO}_{2}$ or $\mathrm{HNO}_{3}$ with Alumina as a Mineral Dust Model Compound, J. Phys. Chem. A, 104, 5036-5045, https://doi.org/10.1021/jp994170d, 2000.

Burkholder, J. B., Abbatt, J. P. D., Huie, R. E., Kurylo, M. J., Wilmouth, D. M., Sander, S. P., Barker, J. R., Kolb, C. E., Orkin, V. L., and Wine, P. H.: Chemical Kinetics and Photochemical Data for Use in Atmospheric Studies, Evaluation No. 18, JPL Publication 15-10, 2015.

Chang, R. Y. W., Sullivan, R. C., and Abbatt, J. P. D.: Initial uptake of ozone on Saharan dust at atmospheric relative humidities, Geophys. Res. Lett., 32, L14815, https://doi.org/10.1029/2005GL023317, 2005.

Cheng, Y. F., Eichler, H., Wiedensohler, A., Heintzenberg, J., Zhang, Y. H., Hu, M., Herrmann, H., Zeng, L. M., Liu, S., Gnauk, T., Brüggemann, E., and He, L. Y.: Mixing state of elemental carbon and non-light-absorbing aerosol components derived from in situ particle optical properties at Xinken in Pearl River Delta of China, J. Geophys. Res.-Atmos., 111, D20204, https://doi.org/10.1029/2005JD006929, 2006.

Cheng, Y. F., Su, H., Rose, D., Gunthe, S. S., Berghof, M., Wehner, B., Achtert, P., Nowak, A., Takegawa, N., Kondo, Y., Shiraiwa, M., Gong, Y. G., Shao, M., Hu, M., Zhu, T., Zhang, Y. H., Carmichael, G. R., Wiedensohler, A., Andreae, M. O., and Pöschl, U.: Size-resolved measurement of the mixing state of soot in the megacity Beijing, China: diurnal cycle, aging and parameterization, Atmos. Chem. Phys., 12, 4477-4491, https://doi.org/10.5194/acp-12-4477-2012, 2012.

Cheng, Y., Su, H., Koop, T., Mikhailov, E., and Pöschl, U.: Size dependence of phase transitions in aerosol nanoparticles, Nat. Commun., 6, 5923, https://doi.org/10.1038/ncomms6923, 2015.
Cheng, Y., Zheng, G., Wei, C., Mu, Q., Zheng, B., Wang, Z., Gao, M., Zhang, Q., He, K., Carmichael, G., Pöschl, U., and Su, H.: Reactive nitrogen chemistry in aerosol water as a source of sulfate during haze events in China, Sci. Adv., 2, e1601530, https://doi.org/10.1126/sciadv.1601530, 2016.

Chen, Y., Wolke, R., Ran, L., Birmili, W., Spindler, G., Schröder, W., Su, H., Cheng, Y., Tegen, I., and Wiedensohler, A.: A parameterization of the heterogeneous hydrolysis of $\mathrm{N}_{2} \mathrm{O}_{5}$ for mass-based aerosol models: improvement of particulate nitrate prediction, Atmos. Chem. Phys., 18, 673-689, https://doi.org/10.5194/acp-18-673-2018, 2018.

Crowley, J. N., Ammann, M., Cox, R. A., Hynes, R. G., Jenkin, M. E., Mellouki, A., Rossi, M. J., Troe, J., and Wallington, T. J.: Evaluated kinetic and photochemical data for atmospheric chemistry: Volume V - heterogeneous reactions on solid substrates, Atmos. Chem. Phys., 10, 9059-9223, https://doi.org/10.5194/acp-10-9059-2010, 2010.

Crowley, J. N., Ammann, M., Cox, R. A., Hynes, R. G., Jenkin, M. E., Mellouki, A., Rossi, M. J., Troe, J., and Wallington, T. J.: Corrigendum to "Evaluated kinetic and photochemical data for atmospheric chemistry: Volume V - heterogeneous reactions on solid substrates" published in Atmos. Chem. Phys. 10, 9059-9223, 2010, Atmos. Chem. Phys., 13, 7359-7359, https://doi.org/10.5194/acp-13-7359-2013, 2013.

de Gouw, J. A. and Lovejoy, E. R.: Reactive uptake of ozone by liquid organic compounds, Geophys. Res. Lett., 25, 931-934, https://doi.org/10.1029/98GL00515, 1998.

de Haan, D. O. and Finlayson-Pitts, B. J.: Knudsen Cell Studies of the Reaction of Gaseous Nitric Acid with Synthetic Sea Salt at 298 K, J. Phys. Chem. A, 101, 9993-9999, https://doi.org/10.1021/jp972450s, 1997.

Dentener, F. J., Carmichael, G. R., Zhang, Y., Lelieveld, J., and Crutzen, P. J.: Role of mineral aerosol as a reactive surface in the global troposphere, J. Geophys. Res.-Atmos., 101, 2286922889, https://doi.org/10.1029/96JD01818, 1996.

Disselkamp, R. S., Carpenter, M. A., Cowin, J. P., Berkowitz, C. M., Chapman, E. G., Zaveri, R. A., and Laulainen, N. S.: Ozone loss in soot aerosols, J. Geophys. Res.-Atmos., 105, 9767-9771, https://doi.org/10.1029/1999JD901189, 2000.

Ditas, J., Ma, N., Zhang, Y., Assmann, D., Neumaier, M., Riede, H., Karu, E., Williams, J., Scharffe, D., Wang, Q., Saturno, J., Schwarz, J. P., Katich, J. M., McMeeking, G. R., Zahn, A., Hermann, M., Brenninkmeijer, C. A. M., Andreae, M. O., Pöschl, U., Su, H., and Cheng, Y.: Strong impact of wildfires on the abundance and aging of black carbon in the lowermost stratosphere, P. Natl. Acad. Sci. USA, 115, E11595, https://doi.org/10.1073/pnas.1806868115, 2018.

Dupart, Y., Fine, L., D'Anna, B., and George, C.: Heterogeneous uptake of $\mathrm{NO}_{2}$ on Arizona Test Dust under UV-A irradiation: An aerosol flow tube study, Aeolian Res., 15, 45-51, https://doi.org/10.1016/j.aeolia.2013.10.001, 2014.

El Zein, A., Romanias, M. N., and Bedjanian, Y.: Heterogeneous Interaction of $\mathrm{H}_{2} \mathrm{O}_{2}$ with Arizona Test Dust, J. Phys. Chem. A, 118, 441-448, https://doi.org/10.1021/jp409946j, 2014.

Evans, M. J. and Jacob, D. J.: Impact of new laboratory studies of $\mathrm{N}_{2} \mathrm{O}_{5}$ hydrolysis on global model budgets of tropospheric nitrogen oxides, ozone, and OH, Geophys. Res. Lett., 32, L09813, https://doi.org/10.1029/2005GL022469, 2005. 
Fenidel, W., Matter, D., Burtscher, H., and Schmidt-Ott, A.: Interaction between carbon or iron aerosol particles and ozone, Atmos. Environ., 29, 967-973, https://doi.org/10.1016/13522310(95)00038-Z, 1995.

Fenter, F. F., Caloz, F., and Rossi, M. J.: Experimental evidence for the efficient "dry deposition" of nitric acid on calcite, Atmos. Environ., 29, 3365-3372, https://doi.org/10.1016/13522310(95)00183-Y, 1995.

Folkers, M., Mentel, T. F., and Wahner, A.: Influence of an organic coating on the reactivity of aqueous aerosols probed by the heterogeneous hydrolysis of $\mathrm{N}_{2} \mathrm{O}_{5}$, Geophys. Res. Lett., 30, 1644, https://doi.org/10.1029/2003GL017168, 2003.

Fowler, D., Pilegaard, K., Sutton, M. A., Ambus, P., Raivonen, M., Duyzer, J., Simpson, D., Fagerli, H., Fuzzi, S., Schjoerring, J. K., Granier, C., Neftel, A., Isaksen, I. S. A., Laj, P., Maione, M., Monks, P. S., Burkhardt, J., Daemmgen, U., Neirynck, J., Personne, E., Wichink-Kruit, R., Butterbach-Bahl, K., Flechard, C., Tuovinen, J. P., Coyle, M., Gerosa, G., Loubet, B., Altimir, N., Gruenhage, L., Ammann, C., Cieslik, S., Paoletti, E., Mikkelsen, T. N., Ro-Poulsen, H., Cellier, P., Cape, J. N., Horváth, L., Loreto, F., Niinemets, Ü., Palmer, P. I., Rinne, J., Misztal, P., Nemitz, E., Nilsson, D., Pryor, S., Gallagher, M. W., Vesala, T., Skiba, U., Brüggemann, N., Zechmeister-Boltenstern, S., Williams, J., O’Dowd, C., Facchini, M. C., de Leeuw, G., Flossman, A., Chaumerliac, N., and Erisman, J. W.: Atmospheric composition change: EcosystemsAtmosphere interactions, Atmos. Environ., 43, 5193-5267, https://doi.org/10.1016/j.atmosenv.2009.07.068, 2009.

Fried, A., Crawford, J., Olson, J., Walega, J., Potter, W., Wert, B., Jordan, C., Anderson, B., Shetter, R., Lefer, B., Blake, D., Blake, N., Meinardi, S., Heikes, B., O’Sullivan, D., Snow, J., Fuelberg, H., Kiley, C. M., Sandholm, S., Tan, D., Sachse, G., Singh, H., Faloona, I., Harward, C. N., and Carmichael, G. R.: Airborne tunable diode laser measurements of formaldehyde during TRACEP: Distributions and box model comparisons, J. Geophys. Res.-Atmos., 108, 8798, https://doi.org/10.1029/2003JD003451, 2003.

Frinak, E. K., Wermeille, S. J., Mashburn, C. D., Tolbert, M. A., and Pursell, C. J.: Heterogeneous Reaction of Gaseous Nitric Acid on $\gamma$-Phase Iron(III) Oxide, J. Phys. Chem. A, 108, 1560-1566, https://doi.org/10.1021/jp030807o, 2004.

Fröhlich-Nowoisky, J., Kampf, C. J., Weber, B., Huffman, J. A., Pöhlker, C., Andreae, M. O., Lang-Yona, N., Burrows, S. M., Gunthe, S. S., Elbert, W., Su, H., Hoor, P., Thines, E., Hoffmann, T., Després, V. R., and Pöschl, U.: Bioaerosols in the Earth system: Climate, health, and ecosystem interactions, Atmos. Res., 182, 346-376, https://doi.org/10.1016/j.atmosres.2016.07.018, 2016.

Ganzeveld, L. and Lelieveld, J.: Dry deposition parameterization in a chemistry general circulation model and its influence on the distribution of reactive trace gases, J. Geophys. Res.-Atmos., 100, 20999-21012, https://doi.org/10.1029/95JD02266, 1995.

Gard, E. E., Kleeman, M. J., Gross, D. S., Hughes, L. S., Allen, J. O., Morrical, B. D., Fergenson, D. P., Dienes, T., E. Gälli, M., Johnson, R. J., Cass, G. R., and Prather, K. A.: Direct Observation of Heterogeneous Chemistry in the Atmosphere, Science, 279, 1184-1187, https://doi.org/10.1126/science.279.5354.1184, 1998.
Gardner, J. A., Watson, L. R., Adewuyi, Y. G., Davidovits, P., Zahniser, M. S., Worsnop, D. R., and Kolb, C. E.: Measurement of the mass accommodation coefficient of $\mathrm{SO}_{2}(\mathrm{~g})$ on water droplets, J. Geophys. Res.-Atmos., 92, 10887-10895, https://doi.org/10.1029/JD092iD09p10887, 1987.

Gebel, M. E., Finlayson-Pitts Barbara, J., and Ganske Jane, A.: The uptake of $\mathrm{SO}_{2}$ on synthetic sea salt and some of its components, Geophys. Res. Lett., 27, 887-890, https://doi.org/10.1029/1999GL011152, 2000.

George, C., Ponche, J. L., Mirabel, P., Behnke, W., Scheer, V., and Zetzsch, C.: Study of the Uptake of $\mathrm{N}_{2} \mathrm{O}_{5}$ by Water and $\mathrm{NaCl}$ Solutions, J. Phys. Chem., 98, 8780-8784, https://doi.org/10.1021/j100086a031, 1994.

George, C., Ammann, M., D’Anna, B., Donaldson, D. J., and Nizkorodov, S. A.: Heterogeneous Photochemistry in the Atmosphere, Chem. Rev., 115, 4218-4258, https://doi.org/10.1021/cr500648z, 2015.

Ghan, S. J., Guzman, G., and Abdul-Razzak, H.: Competition between Sea Salt and Sulfate Particles as Cloud Condensation Nuclei, J. Atmos. Sci., 55, 3340-3347, https://doi.org/10.1175/15200469(1998)055<3340:CBSSAS>2.0.CO;2, 1998.

Goodman, A. L., Underwood, G. M., and Grassian, V. H.: A laboratory study of the heterogeneous reaction of nitric acid on calcium carbonate particles, J. Geophys. Res.-Atmos., 105, 2905329064, https://doi.org/10.1029/2000JD900396, 2000.

Goodman, A. L., Li, P., Usher, C. R., and Grassian, V. H.: Heterogeneous Uptake of Sulfur Dioxide On Aluminum and Magnesium Oxide Particles, J. Phys. Chem. A, 105, 6109-6120, https://doi.org/10.1021/jp004423z, 2001.

Griffiths, P. T., Badger, C. L., Cox, R. A., Folkers, M., Henk, H. H., and Mentel, T. F.: Reactive Uptake of $\mathrm{N}_{2} \mathrm{O}_{5}$ by Aerosols Containing Dicarboxylic Acids. Effect of Particle Phase, Composition, and Nitrate Content, J. Phys. Chem. A, 113, 5082-5090, https://doi.org/10.1021/jp8096814, 2009.

Gross, S., Iannone, R., Xiao, S., and Bertram, A. K.: Reactive uptake studies of $\mathrm{NO}_{3}$ and $\mathrm{N}_{2} \mathrm{O}_{5}$ on alkenoic acid, alkanoate, and polyalcohol substrates to probe nighttime aerosol chemistry, Phys. Chem. Chem Phys., 11, 7792-7803, https://doi.org/10.1039/B904741G, 2009.

Guimbaud, C., Arens, F., Gutzwiller, L., Gäggeler, H. W., and Ammann, M.: Uptake of HNO3 to deliquescent sea-salt particles: a study using the short-lived radioactive isotope tracer ${ }^{13} \mathrm{~N}$, Atmos. Chem. Phys., 2, 249-257, https://doi.org/10.5194/acp-2249-2002, 2002.

Gunthe, S. S., Rose, D., Su, H., Garland, R. M., Achtert, P., Nowak, A., Wiedensohler, A., Kuwata, M., Takegawa, N., Kondo, Y., Hu, M., Shao, M., Zhu, T., Andreae, M. O., and Pöschl, U.: Cloud condensation nuclei $(\mathrm{CCN})$ from fresh and aged air pollution in the megacity region of Beijing, Atmos. Chem. Phys., 11, 1102311039, https://doi.org/10.5194/acp-11-11023-2011, 2011.

Gustafsson, R. J., Orlov, A., Griffiths, P. T., Cox, R. A., and Lambert, R. M.: Reduction of $\mathrm{NO}_{2}$ to nitrous acid on illuminated titanium dioxide aerosol surfaces: implications for photocatalysis and atmospheric chemistry, Chem. Commun., 3936-3938, https://doi.org/10.1039/B609005B, 2006.

Gutzwiller, L., George, C., Rössler, E., and Ammann, M.: Reaction Kinetics of $\mathrm{NO}_{2}$ with Resorcinol and 2,7-Naphthalenediol in the 
Aqueous Phase at Different pH, J. Phys. Chem. A, 106, 1204512050, https://doi.org/10.1021/jp026240d, 2002.

Hallquist, M., Stewart, D. J., Stephenson, S. K., and Anthony Cox, R.: Hydrolysis of $\mathrm{N}_{2} \mathrm{O}_{5}$ on sub-micron sulfate aerosols, Phys. Chem. Chem Phys., 5, 3453-3463, https://doi.org/10.1039/B301827J, 2003.

Hanisch, F. and Crowley, J. N.: Heterogeneous Reactivity of Gaseous Nitric Acid on $\mathrm{Al}_{2} \mathrm{O}_{3}, \mathrm{CaCO}_{3}$, and Atmospheric Dust Samples: A Knudsen Cell Study, J. Phys. Chem. A, 105, 30963106, https://doi.org/10.1021/jp001254+, 2001a.

Hanisch, F. and Crowley, J. N.: The heterogeneous reactivity of gaseous nitric acid on authentic mineral dust samples, and on individual mineral and clay mineral components, Phys. Chem. Chem Phys., 3, 2474-2482, https://doi.org/10.1039/B101700O, 2001b.

Hanisch, F. and Crowley, J. N.: Ozone decomposition on Saharan dust: an experimental investigation, Atmos. Chem. Phys., 3, 119130, https://doi.org/10.5194/acp-3-119-2003, 2003.

Harrison, R. M. and Collins, G. M.: Measurements of Reaction Coefficients of $\mathrm{NO}_{2}$ and $\mathrm{HONO}$ on Aerosol Particles, J. Atmos. Chem., 30, 397-406, https://doi.org/10.1023/A:1006094304069, 1998.

He, H., Wang, Y., Ma, Q., Ma, J., Chu, B., Ji, D., Tang, G., Liu, C., Zhang, H., and Hao, J.: Mineral dust and $\mathrm{NO}_{x}$ promote the conversion of SO2 to sulfate in heavy pollution days, Sci. Rep., 4, 4172, https://doi.org/10.1038/srep04172, 2014.

Hearn, J. D., Lovett, A. J., and Smith, G. D.: Ozonolysis of oleic acid particles: evidence for a surface reaction and secondary reactions involving Criegee intermediates, Phys. Chem. Chem Phys., 7, 501-511, https://doi.org/10.1039/B414472D, 2005.

Held, A., Zerrath, A., McKeon, U., Fehrenbach, T., Niessner, R., Plass-Dülmer, C., Kaminski, U., Berresheim, H., and Pöschl, U.: Aerosol size distributions measured in urban, rural and high-alpine air with an electrical low pressure impactor (ELPI), Atmos. Environ., 42, 8502-8512, https://doi.org/10.1016/j.atmosenv.2008.06.015, 2008.

Herrmann, H.: Kinetics of Aqueous Phase Reactions Relevant for Atmospheric Chemistry, Chem. Rev., 103, 4691-4716, https://doi.org/10.1021/cr020658q, 2003.

Herrmann, H., Schaefer, T., Tilgner, A., Styler, S. A., Weller, C., Teich, M., and Otto, T.: Tropospheric Aqueous-Phase Chemistry: Kinetics, Mechanisms, and Its Coupling to a Changing Gas Phase, Chem. Rev., 115, 4259-4334, https://doi.org/10.1021/cr500447k, 2015.

Hoffman, R. C., Kaleuati, M. A., and Finlayson-Pitts, B. J.: Knudsen Cell Studies of the Reaction of Gaseous $\mathrm{HNO}_{3}$ with $\mathrm{NaCl}$ Using Less than a Single Layer of Particles at $298 \mathrm{~K}$ :? A Modified Mechanism, J. Phys. Chem. A, 107, 7818-7826, https://doi.org/10.1021/jp030611o, 2003.

Huang, L., Zhao, Y., Li, H., and Chen, Z.: Kinetics of Heterogeneous Reaction of Sulfur Dioxide on Authentic Mineral Dust: Effects of Relative Humidity and Hydrogen Peroxide, Environ. Sci. Technol., 49, 10797-10805, https://doi.org/10.1021/acs.est.5b03930, 2015.

Huss, A., Lim, P. K., and Eckert, C. A.: Oxidation of aqueous sulfur dioxide. 1. Homogeneous manganese(II) and iron(II) catalysis at low pH, J. Phys. Chem., 86, 4224-4228, https://doi.org/10.1021/j100218a027, 1982.
Il'in, S. D.: Study of heterogeneous ozone loss on materials typical of atmospheric aerosol species, Sov. J. Chem. Phys., 8, 1858$1880,1991$.

Jacob, D. J.: Heterogeneous chemistry and tropospheric ozone, Atmos. Environ., 34, 2131-2159, https://doi.org/10.1016/S13522310(99)00462-8, 2000.

Jayne, J. T., Gardner, J. A., Davidovits, P., Worsnop, D. R., Zahniser, M. S., and Kolb, C. E.: The effect of $\mathrm{H}_{2} \mathrm{O}_{2}$ content on the uptake of $\mathrm{SO}_{2}(\mathrm{~g})$ by aqueous droplets, J. Geophys. Res.-Atmos., 95, 20559-20563, https://doi.org/10.1029/JD095iD12p20559, 1990.

Jimenez, J. L., Canagaratna, M. R., Donahue, N. M., Prevot, A. S. H., Zhang, Q., Kroll, J. H., DeCarlo, P. F., Allan, J. D., Coe, H., Ng, N. L., Aiken, A. C., Docherty, K. S., Ulbrich, I. M., Grieshop, A. P., Robinson, A. L., Duplissy, J., Smith, J. D., Wilson, K. R., Lanz, V. A., Hueglin, C., Sun, Y. L., Tian, J., Laaksonen, A., Raatikainen, T., Rautiainen, J., Vaattovaara, P., Ehn, M., Kulmala, M., Tomlinson, J. M., Collins, D. R., Cubison, M. J., Dunlea, J., Huffman, J. A., Onasch, T. B., Alfarra, M. R., Williams, P. I., Bower, K., Kondo, Y., Schneider, J., Drewnick, F., Borrmann, S., Weimer, S., Demerjian, K., Salcedo, D., Cottrell, L., Griffin, R., Takami, A., Miyoshi, T., Hatakeyama, S., Shimono, A., Sun, J. Y., Zhang, Y. M., Dzepina, K., Kimmel, J. R., Sueper, D., Jayne, J. T., Herndon, S. C., Trimborn, A. M., Williams, L. R., Wood, E. C., Middlebrook, A. M., Kolb, C. E., Baltensperger, U., and Worsnop, D. R.: Evolution of Organic Aerosols in the Atmosphere, Science, 326, 1525, https://doi.org/10.1126/science.1180353, 2009.

Johnson, E. R., Sciegienka, J., Carlos-Cuellar, S., and Grassian, V. H.: Heterogeneous Uptake of Gaseous Nitric Acid on Dolomite $\left(\mathrm{CaMg}\left(\mathrm{CO}_{3}\right)_{2}\right)$ and Calcite $\left(\mathrm{CaCO}_{3}\right)$ Particles:? A Knudsen Cell Study Using Multiple, Single, and Fractional Particle Layers, J. Phys. Chem. A, 109, 6901-6911, https://doi.org/10.1021/jp0516285, 2005.

Judeikis, H. S., Stewart, T. B., and Wren, A. G.: Laboratory studies of heterogeneous reactions of $\mathrm{SO}_{2}$, Atmos. Environ., 12, 16331641, https://doi.org/10.1016/0004-6981(78)90312-8, 1978.

Kalberer, M., Tabor, K., Ammann, M., Parrat, Y., Weingartner, E., Piguet, D., Rössler, E., Jost, D. T., Türler, A., Gäggeler, H. W., and Baltensperger, U.: Heterogeneous Chemical Processing of $13 \mathrm{NO}_{2}$ by Monodisperse Carbon Aerosols at Very Low Concentrations, J. Phys. Chem., 100, 15487-15493, https://doi.org/10.1021/jp9606974, 1996.

Kalberer, M., Ammann, M., Arens, F., Gäggeler, H. W., and Baltensperger, U.: Heterogeneous formation of nitrous acid (HONO) on soot aerosol particles, J. Geophys. Res.-Atmos., 104, 1382513832, https://doi.org/10.1029/1999JD900141, 1999.

Kamm, S., Möhler, O., Naumann, K. H., Saathoff, H., and Schurath, U.: The heterogeneous reaction of ozone with soot aerosol, Atmos. Environ., 33, 4651-4661, https://doi.org/10.1016/S13522310(99)00235-6, 1999.

Kane, S. M., Caloz, F., and Leu, M.-T.: Heterogeneous Uptake of Gaseous $\mathrm{N}_{2} \mathrm{O}_{5}$ by $\left(\mathrm{NH}_{4}\right)_{2} \mathrm{SO}_{4}, \mathrm{NH}_{4} \mathrm{HSO}_{4}$, and $\mathrm{H}_{2} \mathrm{SO}_{4}$ Aerosols, J. Phys. Chem. A, 105, 6465-6470, https://doi.org/10.1021/jp010490x, 2001.

Karagulian, F. and Rossi, M. J.: Heterogeneous Chemistry of the NO3 Free Radical and $\mathrm{N}_{2} \mathrm{O}_{5}$ on Decane Flame Soot at Ambient Temperature: Reaction Products and Kinetics, J. Phys. Chem. A, 111, 1914-1926, https://doi.org/10.1021/jp0670891, 2007. 
Karagulian, F., Santschi, C., and Rossi, M. J.: The heterogeneous chemical kinetics of $\mathrm{N}_{2} \mathrm{O}_{5}$ on $\mathrm{CaCO}_{3}$ and other atmospheric mineral dust surrogates, Atmos. Chem. Phys., 6, 1373-1388, https://doi.org/10.5194/acp-6-1373-2006, 2006.

King, M. D., Thompson, K. C., Ward, A. D., Pfrang, C., and Hughes, B. R.: Oxidation of biogenic and watersoluble compounds in aqueous and organic aerosol droplets by ozone: a kinetic and product analysis approach using laser Raman tweezers, Faraday Discuss., 137, 173-192, https://doi.org/10.1039/B702199B, 2008.

Kirchner, U., Scheer, V., and Vogt, R.: FTIR Spectroscopic Investigation of the Mechanism and Kinetics of the Heterogeneous Reactions of $\mathrm{NO}_{2}$ and $\mathrm{HNO}_{3}$ with Soot, J. Phys. Chem. A, 104, 8908-8915, https://doi.org/10.1021/jp0005322, 2000.

Kleffmann, J., Becker, K. H., and Wiesen, P.: Heterogeneous $\mathrm{NO}_{2}$ conversion processes on acid surfaces: possible atmospheric implications, Atmos. Environ., 32, 2721-2729, https://doi.org/10.1016/S1352-2310(98)00065-X, 1998.

Kleffmann, J. R., Becker, K. H., Lackhoff, M., and Wiesen, P.: Heterogeneous conversion of $\mathrm{NO}_{2}$ on carbonaceous surfaces, Phys. Chem. Chem. Phys., 5443-5450, 1999.

Knopf, D. A., Anthony, L. M., and Bertram, A. K.: Reactive Uptake of $\mathrm{O}_{3}$ by Multicomponent and Multiphase Mixtures Containing Oleic Acid, J. Phys. Chem. A, 109, 5579-5589, https://doi.org/10.1021/jp0512513, 2005.

Kolb, C. E., Worsnop, D. R., Zahniser, M. S., Davidovits, P., Keyser, L. F., Leu, M. T., Molina, M. J., Hanson, D. R., Ravishankara, A. R., Williams, L. R., and Tolbert, M. A.: Laboratory Studies Of Atmospheric Heterogeneous Chemistry, in: Progress and Problems in Atmospheric Chemistry, Advanced Series in Physical Chemistry, Vol. 3, World Scientific, 771-875, 1995.

Kolb, C. E., Cox, R. A., Abbatt, J. P. D., Ammann, M., Davis, E. J., Donaldson, D. J., Garrett, B. C., George, C., Griffiths, P. T., Hanson, D. R., Kulmala, M., McFiggans, G., Pöschl, U., Riipinen, I., Rossi, M. J., Rudich, Y., Wagner, P. E., Winkler, P. M., Worsnop, D. R., and O' Dowd, C. D.: An overview of current issues in the uptake of atmospheric trace gases by aerosols and clouds, Atmos. Chem. Phys., 10, 10561-10605, https://doi.org/10.5194/acp-1010561-2010, 2010.

Komiyama, H. and Inoue, H.: 20 Absorption of nitrogen oxides into water, Chem. Eng. Sci., 35, 154-161, https://doi.org/10.1016/0009-2509(80)80082-0, 1980.

Lappalainen, H. K., Kerminen, V.-M., Petäjä, T., Kurten, T., Baklanov, A., Shvidenko, A., Bäck, J., Vihma, T., Alekseychik, P., Andreae, M. O., Arnold, S. R., Arshinov, M., Asmi, E., Belan, B., Bobylev, L., Chalov, S., Cheng, Y., Chubarova, N., de Leeuw, G., Ding, A., Dobrolyubov, S., Dubtsov, S., Dyukarev, E., Elansky, N., Eleftheriadis, K., Esau, I., Filatov, N., Flint, M., Fu, C., Glezer, O., Gliko, A., Heimann, M., Holtslag, A. A. M., Hõrrak, U., Janhunen, J., Juhola, S., Järvi, L., Järvinen, H., Kanukhina, A., Konstantinov, P., Kotlyakov, V., Kieloaho, A.-J., Komarov, A. S., Kujansuu, J., Kukkonen, I., Duplissy, E.-M., Laaksonen, A., Laurila, T., Lihavainen, H., Lisitzin, A., Mahura, A., Makshtas, A., Mareev, E., Mazon, S., Matishov, D., Melnikov, V., Mikhailov, E., Moisseev, D., Nigmatulin, R., Noe, S. M., Ojala, A., Pihlatie, M., Popovicheva, O., Pumpanen, J., Regerand, T., Repina, I., Shcherbinin, A., Shevchenko, V., Sipilä, M., Skorokhod, A., Spracklen, D. V., Su, H., Subetto, D. A., Sun, J., Terzhevik, A. Y., Timofeyev, Y., Troitskaya, Y., Tynkkynen, V.-
P., Kharuk, V. I., Zaytseva, N., Zhang, J., Viisanen, Y., Vesala, T., Hari, P., Hansson, H. C., Matvienko, G. G., Kasimov, N. S., Guo, H., Bondur, V., Zilitinkevich, S., and Kulmala, M.: PanEurasian Experiment (PEEX): towards a holistic understanding of the feedbacks and interactions in the land-atmosphere-oceansociety continuum in the northern Eurasian region, Atmos. Chem. Phys., 16, 14421-14461, https://doi.org/10.5194/acp-1614421-2016, 2016.

Laskin, A., Gaspar, D. J., Wang, W., Hunt, S. W., Cowin, J. P., Colson, S. D., and Finlayson-Pitts, B. J.: Reactions at Interfaces As a Source of Sulfate Formation in Sea-Salt Particles, Science, 301, 340-344, https://doi.org/10.1126/science.1085374, 2003.

Lee, J. H. and Tang, I. N.: Accommodation coefficient of gaseous $\mathrm{NO}_{2}$ on water surfaces, Atmos. Environ., 22, 1147-1151, https://doi.org/10.1016/0004-6981(88)90344-7, 1988.

Lee, Y. H., Chen, K., and Adams, P. J.: Development of a global model of mineral dust aerosol microphysics, Atmos. Chem. Phys., 9, 2441-2458, https://doi.org/10.5194/acp-9-2441-2009, 2009.

Lelieveld, J. and Dentener, F. J.: What controls tropospheric ozone?, J. Geophys. Res.-Atmos., 105, 3531-3551, https://doi.org/10.1029/1999JD901011, 2000.

Lelièvre, S., Bedjanian, Y., Laverdet, G., and Le Bras, G.: Heterogeneous Reaction of $\mathrm{NO}_{2}$ with Hydrocarbon Flame Soot, J. Phys. Chem. A, 108, 10807-10817, https://doi.org/10.1021/jp0469970, 2004a.

Lelièvre, S., Bedjanian, Y., Pouvesle, N., Delfau, J.-L., Vovelle, C., and Le Bras, G.: Heterogeneous reaction of ozone with hydrocarbon flame soot, Phys. Chem. Chem Phys., 6, 1181-1191, https://doi.org/10.1039/B316895F, 2004b.

Lewis, E. R. and Schwartz, S. E.: Sea salt Aerosol Production: Mechanisms, Methods, Measurements, and Models, American Geophysical Union, Washington, DC, 2004.

Li, G., Su, H., Li, X., Kuhn, U., Meusel, H., Hoffmann, T., Ammann, M., Pöschl, U., Shao, M., and Cheng, Y.: Uptake of gaseous formaldehyde by soil surfaces: a combination of adsorption/desorption equilibrium and chemical reactions, Atmos. Chem. Phys., 16, 10299-10311, https://doi.org/10.5194/acp-1610299-2016, 2016.

Li, G., Cheng, Y., Kuhn, U., Xu, R., Yang, Y., Meusel, H., Wang, Z., Ma, N., Wu, Y., Li, M., Williams, J., Hoffmann, T., Ammann, M., Pöschl, U., Shao, M., and Su, H.: Physicochemical uptake and release of volatile organic compounds by soil in coated-wall flow tube experiments with ambient air, Atmos. Chem. Phys., 19, 2209-2232, https://doi.org/10.5194/acp-19-2209-2019, 2019.

Li, H. J., Zhu, T., Zhao, D. F., Zhang, Z. F., and Chen, Z. M.: Kinetics and mechanisms of heterogeneous reaction of $\mathrm{NO}_{2}$ on $\mathrm{CaCO}_{3}$ surfaces under dry and wet conditions, Atmos. Chem. Phys., 10, 463-474, https://doi.org/10.5194/acp-10-463-2010, 2010.

Li, H., Chen, Z., Huang, L., and Huang, D.: Organic peroxides' gasparticle partitioning and rapid heterogeneous decomposition on secondary organic aerosol, Atmos. Chem. Phys., 16, 1837-1848, https://doi.org/10.5194/acp-16-1837-2016, 2016.

Li, L., Chen, Z. M., Zhang, Y. H., Zhu, T., Li, J. L., and Ding, $\mathrm{J}$.: Kinetics and mechanism of heterogeneous oxidation of sulfur dioxide by ozone on surface of calcium carbonate, Atmos. Chem. Phys., 6, 2453-2464, https://doi.org/10.5194/acp-6-24532006, 2006. 
Li, X., Rohrer, F., Brauers, T., Hofzumahaus, A., Lu, K., Shao, M., Zhang, Y. H., and Wahner, A.: Modeling of HCHO and CHO$\mathrm{CHO}$ at a semi-rural site in southern China during the PRIDEPRD2006 campaign, Atmos. Chem. Phys., 14, 12291-12305, https://doi.org/10.5194/acp-14-12291-2014, 2014.

Liao, H. and Seinfeld, J. H.: Global impacts of gas-phase chemistryaerosol interactions on direct radiative forcing by anthropogenic aerosols and ozone, J. Geophys. Res.-Atmos., 110, D18208, https://doi.org/10.1029/2005JD005907, 2005.

Liu, F., Lakey, P. S. J., Berkemeier, T., Tong, H., Kunert, A. T., Meusel, H., Cheng, Y., Su, H., Fröhlich-Nowoisky, J., Lai, S., Weller, M. G., Shiraiwa, M., Pöschl, U., and Kampf, C. J.: Atmospheric protein chemistry influenced by anthropogenic air pollutants: nitration and oligomerization upon exposure to ozone and nitrogen dioxide, Faraday Discuss., 200, 413-427, https://doi.org/10.1039/C7FD00005G, 2017.

Liu, Y., Cain, J. P., Wang, H., and Laskin, A.: Kinetic Study of Heterogeneous Reaction of Deliquesced $\mathrm{NaCl}$ Particles with Gaseous $\mathrm{HNO}_{3}$ Using Particle-on-Substrate Stagnation Flow Reactor Approach, J. Phys. Chem. A, 111, 10026-10043, https://doi.org/10.1021/jp072005p, 2007.

Liu, Y., Gibson, Cain, Wang, H., Grassian, and Laskin, A.: Kinetics of Heterogeneous Reaction of $\mathrm{CaCO}_{3}$ Particles with Gaseous $\mathrm{HNO}_{3}$ over a Wide Range of Humidity, J. Phys. Chem. A, 112, 1561-1571, https://doi.org/10.1021/jp076169h, 2008.

Longfellow, C. A., Ravishankara, A. R., and Hanson, D. R.: Reactive and nonreactive uptake on hydrocarbon soot: $\mathrm{HNO}_{3}$, $\mathrm{O}_{3}$, and $\mathrm{N}_{2} \mathrm{O}_{5}$, J. Geophys. Res.-Atmos., 105, 24345-24350, https://doi.org/10.1029/2000JD900297, 2000.

Ma, N. and Birmili, W.: Estimating the contribution of photochemical particle formation to ultrafine particle number averages in an urban atmosphere, Sci. Total Environ., 512-513, 154-166, https://doi.org/10.1016/j.scitotenv.2015.01.009, 2015.

Ma, N., Birmili, W., Müller, T., Tuch, T., Cheng, Y. F., Xu, W. Y., Zhao, C. S., and Wiedensohler, A.: Tropospheric aerosol scattering and absorption over central Europe: a closure study for the dry particle state, Atmos. Chem. Phys., 14, 6241-6259, https://doi.org/10.5194/acp-14-6241-2014, 2014.

McNaughton, C. S., Clarke, A. D., Kapustin, V., Shinozuka, Y., Howell, S. G., Anderson, B. E., Winstead, E., Dibb, J., Scheuer, E., Cohen, R. C., Wooldridge, P., Perring, A., Huey, L. G., Kim, S., Jimenez, J. L., Dunlea, E. J., DeCarlo, P. F., Wennberg, P. O., Crounse, J. D., Weinheimer, A. J., and Flocke, F.: Observations of heterogeneous reactions between Asian pollution and mineral dust over the Eastern North Pacific during INTEX-B, Atmos. Chem. Phys., 9, 8283-8308, https://doi.org/10.5194/acp-9-82832009, 2009.

McNeill, V. F.: Aqueous Organic Chemistry in the Atmosphere: Sources and Chemical Processing of Organic Aerosols, Environ. Sci. Technol., 49, 1237-1244, https://doi.org/10.1021/es5043707, 2015.

Mendez, M., Visez, N., Gosselin, S., Crenn, V., Riffault, V., and Petitprez, D.: Reactive and Nonreactive Ozone Uptake during Aging of Oleic Acid Particles, J. Phys. Chem. A, 118, 9471-9481, https://doi.org/10.1021/jp503572c, 2014.

Meusel, H., Elshorbany, Y., Kuhn, U., Bartels-Rausch, T., Reinmuth-Selzle, K., Kampf, C. J., Li, G., Wang, X., Lelieveld, J., Pöschl, U., Hoffmann, T., Su, H., Ammann, M., and Cheng, Y.: Light-induced protein nitration and degradation with HONO emission, Atmos. Chem. Phys., 17, 11819-11833, https://doi.org/10.5194/acp-17-11819-2017, 2017.

Meusel, H., Tamm, A., Kuhn, U., Wu, D., Leifke, A. L., Fiedler, S., Ruckteschler, N., Yordanova, P., Lang-Yona, N., Pöhlker, M., Lelieveld, J., Hoffmann, T., Pöschl, U., Su, H., Weber, B., and Cheng, Y.: Emission of nitrous acid from soil and biological soil crusts represents an important source of HONO in the remote atmosphere in Cyprus, Atmos. Chem. Phys., 18, 799-813, https://doi.org/10.5194/acp-18-799-2018, 2018.

Michel, A. E., Usher, C. R., and Grassian, V. H.: Heterogeneous and catalytic uptake of ozone on mineral oxides and dusts: A Knudsen cell investigation, Geophys. Res. Lett., 29, 10-14, https://doi.org/10.1029/2002GL014896, 2002.

Michel, A. E., Usher, C. R., and Grassian, V. H.: Reactive uptake of ozone on mineral oxides and mineral dusts, Atmos. Environ., 37, 3201-3211, https://doi.org/10.1016/S1352-2310(03)003194, 2003.

Mochida, M., Hirokawa, J., and Akimoto, H.: Unexpected large uptake of $\mathrm{O}_{3}$ on sea salts and the observed $\mathrm{Br}_{2}$ formation, Geophys. Res. Lett., 27, 2629-2632, https://doi.org/10.1029/1999GL010927, 2000.

Mogili, P. K., Kleiber, P. D., Young, M. A., and Grassian, V. H.: Heterogeneous Uptake of Ozone on Reactive Components of Mineral Dust Aerosol: An Environmental Aerosol Reaction Chamber Study, J. Phys. Chem. A, 110, 13799-13807, https://doi.org/10.1021/jp063620g, 2006.

Moise, T. and Rudich, Y.: Reactive uptake of ozone by proxies for organic aerosols: Surface versus bulk processes, J. Geophys. Res.-Atmos., 105, 14667-14676, https://doi.org/10.1029/2000JD900071, 2000.

Morris, J. W., Davidovits, P., Jayne, J. T., Jimenez, J. L., Shi, Q., Kolb, C. E., Worsnop, D. R., Barney, W. S., and Cass, G.: Kinetics of submicron oleic acid aerosols with ozone: A novel aerosol mass spectrometric technique, Geophys. Res. Lett., 29, 71-74, https://doi.org/10.1029/2002GL014692, 2002.

Msibi, I. M., Shi, J. P., and Harrison, R. M.: Accommodation coefficient for trace gas uptake using deposition profile measurement in an annular reactor, J. Atmos. Chem., 17, 339-351, https://doi.org/10.1007/BF00696853, 1993.

Mu, Q., Shiraiwa, M., Octaviani, M., Ma, N., Ding, A., Su, H., Lammel, G., Pöschl, U., and Cheng, Y.: Temperature effect on phase state and reactivity controls atmospheric multiphase chemistry and transport of PAHs, Sci. Adv., 4, eaap7314, https://doi.org/10.1126/sciadv.aap7314, 2018.

Ndour, M., D’Anna, B., George, C., Ka, O., Balkanski, Y., Kleffmann, J., Stemmler, K., and Ammann, M.: Photoenhanced uptake of $\mathrm{NO}_{2}$ on mineral dust: Laboratory experiments and model simulations, Geophys. Res. Lett., 35, L05812, https://doi.org/10.1029/2007GL032006, 2008.

Ndour, M., Nicolas, M., D’Anna, B., Ka, O., and George, C.: Photoreactivity of $\mathrm{NO}_{2}$ on mineral dusts originating from different locations of the Sahara desert, Phys. Chem. Chem Phys., 11, 1312-1319, https://doi.org/10.1039/B806441E, 2009.

Nicolas, M., Ndour, M., Ka, O., D’Anna, B., and George, C.: Photochemistry of Atmospheric Dust: Ozone Decomposition on Illuminated Titanium Dioxide, Environ. Sci. Technol., 43, 74377442, https://doi.org/10.1021/es901569d, 2009.

O'Dowd, C. D., Smith, M. H., Consterdine, I. E., and Lowe, J. A.: Marine aerosol, sea-salt, and the marine sul- 
phur cycle: a short review, Atmos. Environ., 31, 73-80, https://doi.org/10.1016/S1352-2310(96)00106-9, 1997.

Oswald, R., Behrendt, T., Ermel, M., Wu, D., Su, H., Cheng, Y., Breuninger, C., Moravek, A., Mougin, E., Delon, C., Loubet, B., Pommerening-Röser, A., Sörgel, M., Pöschl, U., Hoffmann, T., Andreae, M. O., Meixner, F. X., and Trebs, I.: HONO Emissions from Soil Bacteria as a Major Source of Atmospheric Reactive Nitrogen, Science, 341, 1233-1235, https://doi.org/10.1126/science.1242266, 2013.

Ouyang, Y., Xu, Z., Fan, E., Li, Y., and Zhang, L.: Effect of nitrogen dioxide and sulfur dioxide on viability and morphology of oak pollen, Int. Forum Allergy Rh., 6, 95-100, https://doi.org/10.1002/alr.21632, 2016.

Pöhlker, C., Wiedemann, K. T., Sinha, B., Shiraiwa, M., Gunthe, S. S., Smith, M., Su, H., Artaxo, P., Chen, Q., Cheng, Y., Elbert, W., Gilles, M. K., Kilcoyne, A. L. D., Moffet, R. C., Weigand, M., Martin, S. T., Pöschl, U., and Andreae, M. O.: Biogenic Potassium Salt Particles as Seeds for Secondary Organic Aerosol in the Amazon, Science, 337, 1075-1078, 2012.

Pöschl, U. and Shiraiwa, M.: Multiphase Chemistry at the Atmosphere-Biosphere Interface Influencing Climate and Public Health in the Anthropocene, Chem. Rev., 115, 4440-4475, https://doi.org/10.1021/cr500487s, 2015.

Pöschl, U., Letzel, T., Schauer, C., and Niessner, R.: Interaction of Ozone and Water Vapor with Spark Discharge Soot Aerosol Particles Coated with Benzo[a]pyrene:? $\mathrm{O}_{3}$ and $\mathrm{H}_{2} \mathrm{O}$ Adsorption, Benzo[a]pyrene Degradation, and Atmospheric Implications, J. Phys. Chem. A, 105, 4029-4041, https://doi.org/10.1021/jp004137n, 2001.

Pöschl, U., Rudich, Y., and Ammann, M.: Kinetic model framework for aerosol and cloud surface chemistry and gas-particle interactions - Part 1: General equations, parameters, and terminology, Atmos. Chem. Phys., 7, 5989-6023, https://doi.org/10.5194/acp7-5989-2007, 2007.

Pöschl, U., Martin, S. T., Sinha, B., Chen, Q., Gunthe, S. S., Huffman, J. A., Borrmann, S., Farmer, D. K., Garland, R. M., Helas, G., Jimenez, J. L., King, S. M., Manzi, A., Mikhailov, E., Pauliquevis, T., Petters, M. D., Prenni, A. J., Roldin, P., Rose, D., Schneider, J., Su, H., Zorn, S. R., Artaxo, P., and Andreae, M. O.: Rainforest Aerosols as Biogenic Nuclei of Clouds and Precipitation in the Amazon, Science, 329, 15131516, https://doi.org/10.1126/science.1191056, 2010.

Ponche, J. L., George, C., and Mirabel, P.: Mass transfer at the air/water interface: Mass accommodation coefficients of $\mathrm{SO} 2, \mathrm{HNO}_{3}, \mathrm{NO}_{2}$ and $\mathrm{NH}_{3}$, J. Atmos. Chem., 16, 1-21, https://doi.org/10.1007/BF00696620, 1993.

Pradhan, M., Kalberer, M., Griffiths, P. T., Braban, C. F., Pope, F. D., Cox, R. A., and Lambert, R. M.: Uptake of Gaseous Hydrogen Peroxide by Submicrometer Titanium Dioxide Aerosol as a Function of Relative Humidity, Environ. Sci. Technol., 44, 13601365, https://doi.org/10.1021/es902916f, 2010a.

Pradhan, M., Kyriakou, G., Archibald, A. T., Papageorgiou, A. C., Kalberer, M., and Lambert, R. M.: Heterogeneous uptake of gaseous hydrogen peroxide by Gobi and Saharan dust aerosols: a potential missing sink for $\mathrm{H}_{2} \mathrm{O}_{2}$ in the troposphere, Atmos. Chem. Phys., 10, 7127-7136, https://doi.org/10.5194/acp-107127-2010, 2010b.

Prince, A. P., Wade, J. L., Grassian, V. H., Kleiber, P. D., and Young, M. A.: Heterogeneous reactions of soot aerosols with nitrogen dioxide and nitric acid: atmospheric chamber and Knudsen cell studies, Atmos. Environ., 36, 5729-5740, https://doi.org/10.1016/S1352-2310(02)00626-X, 2002.

Prospero, J. M.: Long-range transport of mineral dust in the global atmosphere: Impact of African dust on the environment of the southeastern United States, P. Natl. Acad. Sci. USA, 96, 33963403, 1999.

Quinn, P. K., Collins, D. B., Grassian, V. H., Prather, K. A., and Bates, T. S.: Chemistry and Related Properties of Freshly Emitted Sea Spray Aerosol, Chem. Rev., 115, 4383-4399, https://doi.org/10.1021/cr500713g, 2015.

Ravishankara, A. R.: Heterogeneous and Multiphase Chemistry in the Troposphere, Science, 276, 1058-1065, https://doi.org/10.1126/science.276.5315.1058, 1997.

Rissler, J., Vestin, A., Swietlicki, E., Fisch, G., Zhou, J., Artaxo, P., and Andreae, M. O.: Size distribution and hygroscopic properties of aerosol particles from dry-season biomass burning in Amazonia, Atmos. Chem. Phys., 6, 471-491, https://doi.org/10.5194/acp-6-471-2006, 2006.

Rogaski, C. A., Golden, D. M., and Williams, L. R.: Reactive uptake and hydration experiments on amorphous carbon treated with $\mathrm{NO}_{2}, \mathrm{SO}_{2}, \mathrm{O}_{3}, \mathrm{HNO}_{3}$, and $\mathrm{H}_{2} \mathrm{SO}_{4}$, Geophys. Res. Lett., 24, 381-384, https://doi.org/10.1029/97GL00093, 1997.

Romanias, M. N., El Zein, A., and Bedjanian, Y.: Heterogeneous Interaction of $\mathrm{H}_{2} \mathrm{O}_{2}$ with $\mathrm{TiO}_{2}$ Surface under Dark and UV Light Irradiation Conditions, J. Phys. Chem. A, 116, 8191-8200, https://doi.org/10.1021/jp305366v, 2012.

Romanias, M. N., El Zein, A., and Bedjanian, Y.: Uptake of hydrogen peroxide on the surface of $\mathrm{Al}_{2} \mathrm{O}_{3}$ and $\mathrm{Fe}_{2} \mathrm{O}_{3}$, Atmos. Environ., 77, 1-8, https://doi.org/10.1016/j.atmosenv.2013.04.065, 2013.

Rudich, Y., Donahue, N. M., and Mentel, T. F.: Aging of Organic Aerosol: Bridging the Gap Between Laboratory and Field Studies, Ann. Rev. Phys. Chem., 58, 321-352, https://doi.org/10.1146/annurev.physchem.58.032806.104432, 2007.

Saathoff, H., Naumann, K. H., Riemer, N., Kamm, S., Möhler, O., Schurath, U., Vogel, H., and Vogel, B.: The loss of $\mathrm{NO}_{2}$, $\mathrm{HNO}_{3}, \mathrm{NO}_{3} / \mathrm{N}_{2} \mathrm{O}_{5}$, and $\mathrm{HO}_{2} / \mathrm{HOONO}_{2}$ on soot aerosol: $\mathrm{A}$ chamber and modeling study, Geophys. Res. Lett., 28, 19571960, https://doi.org/10.1029/2000GL012619, 2001.

Sadanaga, Y., Hirokawa, J., and Akimoto, H.: Formation of molecular chlorine in dark condition: Heterogeneous reaction of ozone with sea salt in the presence of ferric ion, Geophys. Res. Lett., 28, 4433-4436, https://doi.org/10.1029/2001GL013722, 2001.

Sage, A. M., Weitkamp, E. A., Robinson, A. L., and Donahue, N. M.: Reactivity of oleic acid in organic particles: changes in oxidant uptake and reaction stoichiometry with particle oxidation, Phys. Chem. Chem Phys., 11, 7951-7962, https://doi.org/10.1039/B904285G, 2009.

Salgado-Muñoz, M. S. and Rossi, M. J.: Heterogeneous reactions of $\mathrm{HNO}_{3}$ with flame soot generated under different combustion conditions, Reaction mechanism and kinetics, Phys. Chem. Chem Phys., 4, 5110-5118, https://doi.org/10.1039/B203912P, 2002.

Santschi, C. and Rossi, M. J.: Uptake of $\mathrm{CO} 2, \mathrm{SO} 2, \mathrm{HNO}_{3}$ and $\mathrm{HCl}$ on Calcite $\left(\mathrm{CaCO}_{3}\right)$ at $300 \mathrm{~K}$ : Mechanism and the Role of Adsorbed Water, J. Phys. Chem. A, 110, 6789-6802, https://doi.org/10.1021/jp056312b, 2006. 
Saul, T. D., Tolocka, M. P., and Johnston, M. V.: Reactive Uptake of Nitric Acid onto Sodium Chloride Aerosols Across a Wide Range of Relative Humidities, J. Phys. Chem. A, 110, 76147620, https://doi.org/10.1021/jp060639a, 2006.

Schwartz, S. E.: Mass-Transport Considerations Pertinent to Aqueous Phase Reactions of Gases in Liquid-Water Clouds, Chemistry of Multiphase Atmospheric Systems, Berlin, Heidelberg, 415-471, 1986.

Schwartz, S. E. and Freiberg, J. E.: Mass-transport limitation to the rate of reaction of gases in liquid droplets: Application to oxidation of $\mathrm{SO}_{2}$ in aqueous solutions, Atmos. Environ., 15, 11291144, https://doi.org/10.1016/0004-6981(81)90303-6, 1981.

Schweitzer, F., Mirabel, P., and George, C.: Multiphase Chemistry of $\mathrm{N}_{2} \mathrm{O}_{5}, \mathrm{ClNO}_{2}$, and $\mathrm{BrNO}_{2}$, J. Phys. Chem. A, 102, 39423952, https://doi.org/10.1021/jp980748s, 1998.

Schütze, M. and Herrmann, H.: Determination of phase transfer parameters for the uptake of $\mathrm{HNO}_{3}, \mathrm{~N}_{2} \mathrm{O}_{5}$ and $\mathrm{O}_{3}$ on single aqueous drops, Phys. Chem. Chem Phys., 4, 60-67, https://doi.org/10.1039/B106078N, 2002.

Seinfeld, J. H. and Pandis, S. N.: Atmosppheric chemistry and physics: From air pollution to climate change, John Wiley \& Sons, New York, USA, 2006.

Seisel, S., Börensen, C., Vogt, R., and Zellner, R.: Kinetics and mechanism of the uptake of $\mathrm{N} 2 \mathrm{O} 5$ on mineral dust at $298 \mathrm{~K}$, Atmos. Chem. Phys., 5, 3423-3432, https://doi.org/10.5194/acp-53423-2005, 2005.

Shiraiwa, M., Pfrang, C., and Pöschl, U.: Kinetic multi-layer model of aerosol surface and bulk chemistry (KM-SUB): the influence of interfacial transport and bulk diffusion on the oxidation of oleic acid by ozone, Atmos. Chem. Phys., 10, 3673-3691, https://doi.org/10.5194/acp-10-3673-2010, 2010.

Shiraiwa, M., Ammann, M., Koop, T., and Pöschl, U.: Gas uptake and chemical aging of semisolid organic aerosol particles, P. Natl. Acad. Sci. USA, 108, 11003-11008, https://doi.org/10.1073/pnas.1103045108, 2011.

Shiraiwa, M., Li, Y., Tsimpidi, A. P., Karydis, V. A., Berkemeier, T., Pandis, S. N., Lelieveld, J., Koop, T., and Pöschl, U.: Global distribution of particle phase state in atmospheric secondary organic aerosols, Nat. Commun., 8, 15002, https://doi.org/10.1038/ncomms15002, 2017.

Smith, G. D., Woods, E., DeForest, C. L., Baer, T., and Miller, R. E.: Reactive Uptake of Ozone by Oleic Acid Aerosol Particles: Application of Single-Particle Mass Spectrometry to Heterogeneous Reaction Kinetics, J. Phys. Chem. A, 106, 8085-8095, https://doi.org/10.1021/jp020527t, 2002.

Smith, M. H., Park, P. M., and Consterdine, I. E.: Marine aerosol concentrations and estimated fluxes over the sea, Q. J. Roy. Meteor. Soc., 119, 809-824, https://doi.org/10.1002/qj.49711951211, 1993.

Song, C. H. and Carmichael, G. R.: The aging process of naturally emitted aerosol (sea-salt and mineral aerosol) during long range transport, Atmos. Environ., 33, 2203-2218, https://doi.org/10.1016/S1352-2310(98)00301-X, 1999.

Song, C. H. and Carmichael, G. R.: A three-dimensional modeling investigation of the evolution processes of dust and sea-salt particles in east Asia, J. Geophys. Res.-Atmos., 106, 18131-18154, https://doi.org/10.1029/2000JD900352, 2001.

Spindler, G., Hesper, J., Brüggemann, E., Dubois, R., Müller, T., and Herrmann, H.: Wet annular denuder measurements of nitrous acid: laboratory study of the artefact reaction of $\mathrm{NO}_{2}$ with $\mathrm{S}(\mathrm{IV})$ in aqueous solution and comparison with field measurements, Atmos. Environ., 37, 2643-2662, https://doi.org/10.1016/S13522310(03)00209-7, 2003.

Stadtler, S., Simpson, D., Schröder, S., Taraborrelli, D., Bott, A., and Schultz, M.: Ozone impacts of gas-aerosol uptake in global chemistry transport models, Atmos. Chem. Phys., 18, 31473171, https://doi.org/10.5194/acp-18-3147-2018, 2018.

Stanier, C. O., Khlystov, A. Y., and Pandis, S. N.: Ambient aerosol size distributions and number concentrations measured during the Pittsburgh Air Quality Study (PAQS), Atmos. Environ., 38, 3275-3284, https://doi.org/10.1016/j.atmosenv.2004.03.020, 2004.

Stemmler, K., Vlasenko, A., Guimbaud, C., and Ammann, M.: The effect of fatty acid surfactants on the uptake of nitric acid to deliquesced $\mathrm{NaCl}$ aerosol, Atmos. Chem. Phys., 8, 5127-5141, https://doi.org/10.5194/acp-8-5127-2008, 2008.

Stephens, S., Rossi, M. J., and Golden, D. M.: The Heterogeneous Reaction of Ozone on Carbonaceous Surfaces, Int. J. Chem. Kinet., 18, 1133-1149, https://doi.org/10.1002/kin.550181004, 1986.

Stewart, D. J., Griffiths, P. T., and Cox, R. A.: Reactive uptake coefficients for heterogeneous reaction of $\mathrm{N}_{2} \mathrm{O}_{5}$ with submicron aerosols of $\mathrm{NaCl}$ and natural sea salt, Atmos. Chem. Phys., 4, 1381-1388, https://doi.org/10.5194/acp-4-1381-2004, 2004.

Su, H., Cheng, Y. F., Cheng, P., Zhang, Y. H., Dong, S., Zeng, L. M., Wang, X., Slanina, J., Shao, M., and Wiedensohler, A.: Observation of nighttime nitrous acid (HONO) formation at a nonurban site during PRIDE-PRD2004 in China, Atmos. Environ., 42, 6219-6232, https://doi.org/10.1016/j.atmosenv.2008.04.006, 2008a.

Su, H., Cheng, Y. F., Shao, M., Gao, D. F., Yu, Z. Y., Zeng, L. M., Slanina, J., Zhang, Y. H., and Wiedensohler, A.: Nitrous acid (HONO) and its daytime sources at a rural site during the 2004 PRIDE-PRD experiment in China, J. Geophys. Res.-Atmos., 113, D14312, https://doi.org/10.1029/2007JD009060, 2008b.

Su, H., Cheng, Y., Oswald, R., Behrendt, T., Trebs, I., Meixner, F. X., Andreae, M. O., Cheng, P., Zhang, Y., and Pöschl, U.: Soil Nitrite as a Source of Atmospheric HONO and OH Radicals, Science, 333, 1616-1618, https://doi.org/10.1126/science.1207687, 2011.

Su, H., Cheng, Y., and Pöschl, U.: The Exchange of Soil Nitrite and Atmospheric HONO: A Missing Process in the Nitrogen Cycle and Atmospheric Chemistry, in: Disposal of Dangerous Chemicals in Urban Areas and Mega Cities: Role of Oxides and Acids of Nitrogen in Atmospheric Chemistry, edited by: Barnes, I. and Rudzinski, K. J., Springer Netherlands, Dordrecht, 93-99, 2013.

Sullivan, R. C., Thornberry, T., and Abbatt, J. P. D.: Ozone decomposition kinetics on alumina: effects of ozone partial pressure, relative humidity and repeated oxidation cycles, Atmos. Chem. Phys., 4, 1301-1310, https://doi.org/10.5194/acp-4-1301-2004, 2004.

Tan, F., Tong, S., Jing, B., Hou, S., Liu, Q., Li, K., Zhang, Y., and Ge, M.: Heterogeneous reactions of $\mathrm{NO}_{2}$ with $\mathrm{CaCO}_{3}--\left(\mathrm{NH}_{4}\right)_{2} \mathrm{SO}_{4}$ mixtures at different relative humidities, Atmos. Chem. Phys., 16, 8081-8093, https://doi.org/10.5194/acp-16-8081-2016, 2016.

Tang, M. J., Thieser, J., Schuster, G., and Crowley, J. N.: Kinetics and mechanism of the heterogeneous reaction of $\mathrm{N}_{2} \mathrm{O}_{5}$ with 
mineral dust particles, Phys. Chem. Chem Phys., 14, 8551-8561, https://doi.org/10.1039/C2CP40805H, 2012.

Tang, M. J., Cox, R. A., and Kalberer, M.: Compilation and evaluation of gas phase diffusion coefficients of reactive trace gases in the atmosphere: volume 1. Inorganic compounds, Atmos. Chem. Phys., 14, 9233-9247, https://doi.org/10.5194/acp14-9233-2014, 2014a.

Tang, M. J., Schuster, G., and Crowley, J. N.: Heterogeneous reaction of $\mathrm{N}_{2} \mathrm{O}_{5}$ with illite and Arizona test dust particles, Atmos. Chem. Phys., 14, 245-254, https://doi.org/10.5194/acp-14-2452014, 2014b.

Tang, M., Cziczo, D. J., and Grassian, V. H.: Interactions of Water with Mineral Dust Aerosol: Water Adsorption, Hygroscopicity, Cloud Condensation, and Ice Nucleation, Chem. Rev., 116, 4205-4259, https://doi.org/10.1021/acs.chemrev.5b00529, 2016.

Tang, M., Huang, X., Lu, K., Ge, M., Li, Y., Cheng, P., Zhu, T., Ding, A., Zhang, Y., Gligorovski, S., Song, W., Ding, X., Bi, X., and Wang, X.: Heterogeneous reactions of mineral dust aerosol: implications for tropospheric oxidation capacity, Atmos. Chem. Phys., 17, 11727-11777, https://doi.org/10.5194/acp-17-117272017, 2017.

Thornton, J. A. and Abbatt, J. P. D.: $\mathrm{N}_{2} \mathrm{O}_{5}$ Reaction on Submicron Sea Salt Aerosol:? Kinetics, Products, and the Effect of Surface Active Organics, J. Phys. Chem. A, 109, 10004-10012, https://doi.org/10.1021/jp054183t, 2005.

Thornton, J. A., Braban, C. F., and Abbatt, J. P. D.: $\mathrm{N}_{2} \mathrm{O}_{5}$ hydrolysis on sub-micron organic aerosols: the effect of relative humidity, particle phase, and particle size, Phys. Chem. Chem Phys., 5, 4593-4603, https://doi.org/10.1039/B307498F, 2003.

Tolocka, M. P., Saul, T. D., and Johnston, M. V.: Reactive Uptake of Nitric Acid into Aqueous Sodium Chloride Droplets Using RealTime Single-Particle Mass Spectrometry, J. Phys. Chem. A, 108, 2659-2665, https://doi.org/10.1021/jp036612y, 2004.

Ullerstam, M., Vogt, R., Langer, S., and Ljungstrom, E.: The kinetics and mechanism of $\mathrm{SO}_{2}$ oxidation by $\mathrm{O}_{3}$ on mineral dust, Phys. Chem. Chem Phys., 4, 4694-4699, https://doi.org/10.1039/B203529B, 2002.

Ullerstam, M., Johnson, M. S., Vogt, R., and Ljungström, E.: DRIFTS and Knudsen cell study of the heterogeneous reactivity of $\mathrm{SO}_{2}$ and $\mathrm{NO}_{2}$ on mineral dust, Atmos. Chem. Phys., 3, 2043-2051, https://doi.org/10.5194/acp-3-2043-2003, 2003.

Umann, B., Arnold, F., Schaal, C., Hanke, M., Uecker, J., Aufmhoff, H., Balkanski, Y., and Van Dingenen, R.: Interaction of mineral dust with gas phase nitric acid and sulfur dioxide during the MINATROC II field campaign: First estimate of the uptake coefficient from atmospheric data, J. Geophys. Res.-Atmos., 110, D22306, https://doi.org/10.1029/2005JD005906, 2005.

Underwood, G. M., Li, P., Al-Abadleh, H., and Grassian, V. H.: A Knudsen Cell Study of the Heterogeneous Reactivity of Nitric Acid on Oxide and Mineral Dust Particles, J. Phys. Chem. A, 105, 6609-6620, https://doi.org/10.1021/jp002223h, 2001a.

Underwood, G. M., Song, C. H., Phadnis, M., Carmichael, G. R., and Grassian, V. H.: Heterogeneous reactions of $\mathrm{NO}_{2}$ and $\mathrm{HNO}_{3}$ on oxides and mineral dust: A combined laboratory and modeling study, J. Geophys. Res.-Atmos., 106, 18055-18066, https://doi.org/10.1029/2000JD900552, 2001b.

Usher, C. R., Al-Hosney, H., Carlos-Cuellar, S., and Grassian, V. H.: A laboratory study of the heterogeneous uptake and oxidation of sulfur dioxide on mineral dust particles, J. Geophys.
Res.-Atmos., 107, 4713, https://doi.org/10.1029/2002JD002051, 2002.

Usher, C. R., Michel, A. E., and Grassian, V. H.: Reactions on Mineral Dust, Chem. Rev., 103, 4883-4940, https://doi.org/10.1021/cr020657y, 2003.

Virtanen, A., Joutsensaari, J., Koop, T., Kannosto, J., Yli-Pirilä, P., Leskinen, J., Mäkelä, J. M., Holopainen, J. K., Pöschl, U., Kulmala, M., Worsnop, D. R., and Laaksonen, A.: An amorphous solid state of biogenic secondary organic aerosol particles, Nature, 467, 824-827, https://doi.org/10.1038/nature09455, 2010

Vlasenko, A., Sjogren, S., Weingartner, E., Stemmler, K., Gäggeler, H. W., and Ammann, M.: Effect of humidity on nitric acid uptake to mineral dust aerosol particles, Atmos. Chem. Phys., 6, 21472160, https://doi.org/10.5194/acp-6-2147-2006, 2006.

Vogt, R. and Finlayson-Pitts, B. J.: A Diffuse Reflectance Infrared Fourier Transform Spectroscopic Study of the Surface Reaction of $\mathrm{NaCl}$ with Gaseous $\mathrm{NO}_{2}$ and $\mathrm{HNO}_{3}$, J. Phys. Chem., 98, 3747-3755, https://doi.org/10.1021/j100065a033, 1994.

Wagner, C., Hanisch, F., Holmes, N., de Coninck, H., Schuster, G., and Crowley, J. N.: The interaction of $\mathrm{N}_{2} \mathrm{O}_{5}$ with mineral dust: aerosol flow tube and Knudsen reactor studies, Atmos. Chem. Phys., 8, 91-109, https://doi.org/10.5194/acp-8-91-2008, 2008.

Wagner, C., Schuster, G., and Crowley, J. N.: An aerosol flow tube study of the interaction of $\mathrm{N}_{2} \mathrm{O}_{5}$ with calcite, Arizona dust and quartz, Atmos. Environ., 43, 5001-5008, https://doi.org/10.1016/j.atmosenv.2009.06.050, 2009.

Wagner, V., von Glasow, R., Fischer, H., and Crutzen, P. J.: Are $\mathrm{CH}_{2} \mathrm{O}$ measurements in the marine boundary layer suitable for testing the current understanding of $\mathrm{CH}_{4}$ photooxidation?: A model study, J. Geophys. Res.-Atmos., 107, 4029, https://doi.org/10.1029/2001JD000722, 2002.

Wang, K., Zhang, Y., Nenes, A., and Fountoukis, C.: Implementation of dust emission and chemistry into the Community Multiscale Air Quality modeling system and initial application to an Asian dust storm episode, Atmos. Chem. Phys., 12, 1020910237, https://doi.org/10.5194/acp-12-10209-2012, 2012.

Wang, X., Wang, W., Yang, L., Gao, X., Nie, W., Yu, Y., Xu, P., Zhou, Y., and Wang, Z.: The secondary formation of inorganic aerosols in the droplet mode through heterogeneous aqueous reactions under haze conditions, Atmos. Environ., 63, 68-76, https://doi.org/10.1016/j.atmosenv.2012.09.029, 2012.

Wang, Y., Zhuang, G., Sun, Y., and An, Z.: The variation of characteristics and formation mechanisms of aerosols in dust, haze, and clear days in Beijing, Atmos. Environ., 40, 6579-6591, https://doi.org/10.1016/j.atmosenv.2006.05.066, 2006.

Weber, B., Wu, D., Tamm, A., Ruckteschler, N., RodríguezCaballero, E., Steinkamp, J., Meusel, H., Elbert, W., Behrendt, T., Sörgel, M., Cheng, Y., Crutzen, P. J., Su, H., and Pöschl, U.: Biological soil crusts accelerate the nitrogen cycle through large $\mathrm{NO}$ and HONO emissions in drylands, P. Natl. Acad. Sci. USA, 112, 15384, https://doi.org/10.1073/pnas.1515818112, 2015.

Wesely, M. L.: Parameterization of surface resistances to gaseous dry deposition in regional-scale numerical models, Atmos. Environ., 23, 1293-1304, https://doi.org/10.1016/00046981(89)90153-4, 1989.

Wesely, M. L.: Parameterization of surface resistances to gaseous dry deposition in regional-scale numerical models, Atmos. Environ., 41, 52-63, https://doi.org/10.1016/j.atmosenv.2007.10.058, 2007. 
Wesely, M. L. and Hicks, B. B.: A review of the current status of knowledge on dry deposition, Atmos. Environ., 34, 2261-2282, https://doi.org/10.1016/S1352-2310(99)00467-7, 2000.

Woo, K. S., Chen, D. R., Pui, D. Y. H., and McMurry, P. H.: Measurement of Atlanta Aerosol Size Distributions: Observations of Ultrafine Particle Events, Aerosol Sci. Technol., 34, 75-87, https://doi.org/10.1080/02786820120056, 2001.

Worsnop, D. R., Zahniser, M. S., Kolb, C. E., Gardner, J. A., Watson, L. R., Van Doren, J. M., Jayne, J. T., and Davidovits, P.: The temperature dependence of mass accommodation of sulfur dioxide and hydrogen peroxide on aqueous surfaces, J. Phys. Chem., 93, 1159-1172, https://doi.org/10.1021/j100340a027, 1989.

$\mathrm{Wu}, \mathrm{Z} ., \mathrm{Hu}, \mathrm{M}$. , Lin, P., Liu, S., Wehner, B., and Wiedensohler, A.: Particle number size distribution in the urban atmosphere of Beijing, China, Atmos. Environ., 42, 7967-7980, https://doi.org/10.1016/j.atmosenv.2008.06.022, 2008.

Wu, Z. J., Ma, N., Größ, J., Kecorius, S., Lu, K. D., Shang, D. J., Wang, Y., Wu, Y. S., Zeng, L. M., Hu, M., Wiedensohler, A., and Zhang, Y. H.: Thermodynamic properties of nanoparticles during new particle formation events in the atmosphere of North China Plain, Atmos. Res., 188, 55-63, https://doi.org/10.1016/j.atmosres.2017.01.007, 2017.

Xu, W., Li, Q., Shang, J., Liu, J., Feng, X., and Zhu, T.: Heterogeneous oxidation of $\mathrm{SO}_{2}$ by $\mathrm{O}_{3}$-aged black carbon and its dithiothreitol oxidative potential, J. Environ. Sci., 36, 56-62, https://doi.org/10.1016/j.jes.2015.02.014, 2015.

Yabushita, A., Enami, S., Sakamoto, Y., Kawasaki, M., Hoffmann, M. R., and Colussi, A. J.: Anion-Catalyzed Dissolution of $\mathrm{NO}_{2}$ on Aqueous Microdroplets, J. Phys. Chem. A, 113, 4844-4848, https://doi.org/10.1021/jp900685f, 2009.

Ye, C., Li, H., Zhu, T., Shang, J., Zhang, Z., and Zhao, D.: Heterogeneous reaction of $\mathrm{NO}_{2}$ with sea salt particles, Science China Chemistry, 53, 2652-2656, https://doi.org/10.1007/s11426-0104159-9, 2010

Zhang, L., Brook, J. R., and Vet, R.: On ozone dry deposition with emphasis on non-stomatal uptake and wet canopies, Atmos. Environ., 36, 4787-4799, https://doi.org/10.1016/S13522310(02)00567-8, 2002.

Zhang, L., Brook, J. R., and Vet, R.: A revised parameterization for gaseous dry deposition in air-quality models, Atmos. Chem. Phys., 3, 2067-2082, https://doi.org/10.5194/acp-3-2067-2003, 2003.

Zhang, Q.: China Standard Meteorological Database for Construction (CD-ROM), China Mechanical Industry Press, Beijing, 2004.
Zhang, Y. and Carmichael, G. R.: The Role of Mineral Aerosol in Tropospheric Chemistry in East Asia - A Model Study, J. Appl. Meteorol., 38, 353-366, https://doi.org/10.1175/15200450(1999)038<0353:TROMAI >2.0.CO;2, 1999.

Zhang, Y., Tong, S., Ge, M., Jing, B., Hou, S., Tan, F., Chen, Y., Guo, Y., and Wu, L.: The influence of relative humidity on the heterogeneous oxidation of sulfur dioxide by ozone on calcium carbonate particles, Sci. Total Environ., 633, 1253-1262, https://doi.org/10.1016/j.scitotenv.2018.03.288, 2018.

Zhao, Y., Chen, Z., Shen, X., and Zhang, X.: Kinetics and Mechanisms of Heterogeneous Reaction of Gaseous Hydrogen Peroxide on Mineral Oxide Particles, Environ. Sci. Technol., 45, 33173324, https://doi.org/10.1021/es104107c, 2011.

Zheng, B., Zhang, Q., Zhang, Y., He, K. B., Wang, K., Zheng, G. J., Duan, F. K., Ma, Y. L., and Kimoto, T.: Heterogeneous chemistry: a mechanism missing in current models to explain secondary inorganic aerosol formation during the January 2013 haze episode in North China, Atmos. Chem. Phys., 15, 2031-2049, https://doi.org/10.5194/acp-15-2031-2015, 2015.

Zheng, G. J., Duan, F. K., Su, H., Ma, Y. L., Cheng, Y., Zheng, B., Zhang, Q., Huang, T., Kimoto, T., Chang, D., Pöschl, U., Cheng, Y. F., and He, K. B.: Exploring the severe winter haze in Beijing: the impact of synoptic weather, regional transport and heterogeneous reactions, Atmos. Chem. Phys., 15, 2969-2983, https://doi.org/10.5194/acp-15-2969-2015, 2015.

Zhou, J., Swietlicki, E., Hansson, H. C., and Artaxo, P.: Submicrometer aerosol particle size distribution and hygroscopic growth measured in the Amazon rain forest during the wet season, J. Geophys. Res.-Atmos., 107, 8055, https://doi.org/10.1029/2000JD000203, 2002.

Zhou, L., Wang, W., Ge, M., and Tong, S.: Heterogeneous uptake of gaseous hydrogen peroxide on mineral dust, J. Environ. Sci., 40, 44-50, https://doi.org/10.1016/j.jes.2015.08.018, 2016.

Zhou, X., Lee, Y.-N., Newman, L., Chen, X., and Mopper, K.: Tropospheric formaldehyde concentration at the Mauna Loa Observatory during the Mauna Loa Observatory Photochemistry Experiment 2, J. Geophys. Res.-Atmos., 101, 14711-14719, https://doi.org/10.1029/95JD03226, 1996.

Zhu, S., Butler, T., Sander, R., Ma, J., and Lawrence, M. G.: Impact of dust on tropospheric chemistry over polluted regions: a case study of the Beijing megacity, Atmos. Chem. Phys., 10, 38553873, https://doi.org/10.5194/acp-10-3855-2010, 2010. 